\title{
Optimization of versatile oxindoles as selective PI3K $\delta$ inhibitors
}

Joey L. Methot, ${ }^{*, a}$ Abdelghani Achab, ${ }^{a}$ Matthew Christopher, ${ }^{a}$ Hua Zhou, ${ }^{a}$ Meredeth A. McGowan, ${ }^{a}$ B. Wesley Trotter, ${ }^{a}$ Xavier Fradera, ${ }^{b}$ Charles A. Lesburg, ${ }^{b}$ Peter Goldenblatt, ${ }^{c}$ Armetta Hill, ${ }^{c}$ Dapeng Chen, ${ }^{d}$ Karin M. Otte, ${ }^{d}$ Martin Augustin, ${ }^{e}$ Sanjiv Shah, ${ }^{c}$ Jason D. Katz ${ }^{a}$

${ }^{a}$ Discovery Chemistry, ${ }^{b}$ Computational and Structural Chemistry, cIn Vitro Pharmacology, dPharmacokinetics, Pharmacodynamics and Drug

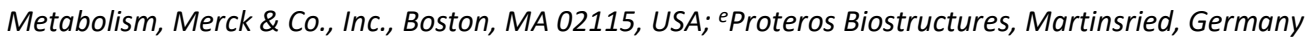

\section{Supporting Information}

\section{Contents:}

Procedures for compound synthesis.

Biochemical, cell and whole blood assay protocols.

Kinome selectivity data tables for compounds $\mathbf{4 c}, \mathbf{4 d}, \mathbf{5 d}, \mathbf{5 e}$.

High dose rat PK for $\mathbf{4 d}$ and $\mathbf{5 d}$.

${ }^{1} \mathrm{H}$ NMR and ${ }^{13} \mathrm{C}$ NMR spectra for $\mathbf{4 d}$ and $\mathbf{5 d}$. 


\section{Procedures for Compound Synthesis.}

\section{General Synthetic Chemistry Methods.}

Reactions were performed in dried round bottom flasks or capped vials with stirring under an inert atmosphere of nitrogen unless stated otherwise. Solvents such as anhydrous THF, DMF, DCM, toluene were purchased from Acros Organics or Sigma-Aldrich in septum-sealed bottles and used as. All temperatures are in degrees Celsius $\left({ }^{\circ} \mathrm{C}\right)$, and ambient temperature is $20^{\circ} \mathrm{C}$. Microwave reactions were performed with a Biotage Initiator Series microwave. Compounds were purified by reverse-phase preparative HPLC or MPLC on silica gel. The course of the reactions was followed by LC/MS (30 mm x $2 \mathrm{~mm}, 2 \mu \mathrm{m}$ column; 3\% to 98\% MeCN/water with $0.05 \%$ TFA gradient over 2.3 minutes; $0.9 \mathrm{~mL} / \mathrm{min}$ flow rate; ESI; UV detection at 254 $\mathrm{nm}$ ). Products were analyzed by NMR, LC/MS and HRMS. HRMS was obtained with a Waters Acquity UPLC with BEH C18 1.7 um column coupled to a Waters Xevo G2 QTof ESI+ MS. NMR spectra were recorded on either a 300, 400, 500 or a $600 \mathrm{MHz}$ Varian spectrometer, chemical shifts are reported in parts per million (ppm) relative to tetramethylsilane and referenced to residual solvent. Coupling constants are reported in $\mathrm{Hz}$. The purity of all compounds screened in the biological assays was examined by LC/MS analysis and was found to be $\geq 95 \%$ unless otherwise specified. The bioactive enantiomer was identified by biological activity measurement in each case.

\section{Intermediate 6-Chloro-9-ethyl-8-(2-methylpyrimidin-5-yl)-9H-purine.}<smiles>Nc1ncnc(Cl)c1N</smiles>

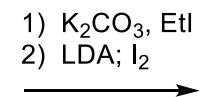<smiles>CCn1c(I)nc2c(Cl)ncnc21</smiles><smiles>CCCC</smiles><smiles>Brc1cnc(I)nc1</smiles>

3) $\mathrm{Me}_{2} \mathrm{Zn}$, $\mathrm{Pd}\left(\mathrm{PPh}_{3}\right)_{4}$ 4) $\mathrm{BuLi}, \mathrm{B}(\mathrm{OiPr})_{3}$<smiles>CCCC</smiles>
5) $\mathrm{Pd}(\mathrm{dppf}) \mathrm{Cl}_{2}$<smiles>CCn1c(-c2cnc(C)nc2)nc2c(Cl)ncnc21</smiles>

Steps 1-2: Into a 10-L 4-neck round-bottom flask was placed a solution of 6-chloro-9H-purine (500 g, 3.24 mol), iodoethane (1009 g, 6.47 mol) and potassium carbonate $(447 \mathrm{~g}, 3.23 \mathrm{~mol})$ in DMSO $(5 \mathrm{~L})$. The resulting solution was stirred overnight at room temperature. It was then diluted with brine and extracted with $3 \times 1.5 \mathrm{~L}$ of ethyl acetate. The organic extracts were combined, dried over anhydrous magnesium sulfate and concentrated under vacuum. The residue was purified by chromatography on $\mathrm{SiO}_{2}$ (1:2 EtOAc/petroleum ether) providing 6-chloro-9-ethyl-9Hpurine $(240 \mathrm{~g}, 41 \%)$. Into a 10 -L 4-neck round-bottom flask purged and maintained with an inert atmosphere of nitrogen was placed a solution of diisopropylamine $(200 \mathrm{~g}, 1.98 \mathrm{~mol})$ in THF $(1.2 \mathrm{~L})$. This was followed by addition of a $2.5 \mathrm{M}$ solution of $n$-BuLi $(736 \mathrm{~mL}, 1.40 \mathrm{equiv})$ at $-78{ }^{\circ} \mathrm{C}$. After stirring for $30 \mathrm{~min}$, a solution of 6-chloro-9-ethyl-9H-purine $(240 \mathrm{~g}, 1.31 \mathrm{~mol})$ in THF $(1.2 \mathrm{~L})$ was added dropwise with stirring at $-78^{\circ} \mathrm{C}$. The resulting solution was stirred for $5 \mathrm{~min}$ at $-78^{\circ} \mathrm{C}$, followed by addition of a solution of $\mathrm{I}_{2}(467 \mathrm{~g}, 1.84 \mathrm{~mol})$ in THF $(1.2 \mathrm{~L})$ at $-78^{\circ} \mathrm{C}$. The resulting solution was stirred for an additional $10 \mathrm{~min}$ at $-78^{\circ} \mathrm{C}$, then quenched by the addition of $200 \mathrm{~mL}$ of aqueous $\mathrm{NH}_{4} \mathrm{Cl}$. The organic layer was washed with $2 \times 1.5 \mathrm{~L}$ of aqueous $\mathrm{Na}_{2} \mathrm{~S}_{2} \mathrm{O}_{3}$, dried $\left(\mathrm{MgSO}_{4}\right)$ and concentrated under vacuum. The obtained solid was washed with $2 \times 200 \mathrm{~mL}$ of ethyl ether to give 6-chloro-9-ethyl-8-iodo-9H-purine ( $250 \mathrm{~g}, 62 \%)$.

Steps 3-4: Into a 10-L 4-neck round-bottom flask purged and maintained with an inert atmosphere of nitrogen was placed a solution of 5-bromo-2iodopyrimidine $(590 \mathrm{~g}, 2.07 \mathrm{~mol}$ ) in THF ( $3 \mathrm{~L})$. This was followed by dropwise addition of $1 \mathrm{M}$ solution of dimethyl zinc (3.11 L, $3.11 \mathrm{~mol})$ with stirring at $0{ }^{\circ} \mathrm{C}$. To this was added $\mathrm{Pd}\left(\mathrm{PPh}_{3}\right)_{4}(120 \mathrm{~g}, 104 \mathrm{mmol})$. The resulting solution was stirred for $3 \mathrm{~h}$ at $0{ }^{\circ} \mathrm{C}$, then quenched by the addition of $600 \mathrm{~mL}$ of aqueous $\mathrm{NH}_{4} \mathrm{Cl}$. The resulting solution was extracted with $2 \times 1.5 \mathrm{~L}$ of EtOAc. The organic extracts were combined, dried (MgSO $\left.{ }_{4}\right)$ and concentrated under vacuum. The residue was purified by chromatography on $\mathrm{SiO}_{2}$ (1:50 EtOAc/petroleum ether) to provide 5-bromo-2methylpyrimidine (184 g, 51\%). Into a 10-L 4-neck round-bottom flask purged and maintained with an inert atmosphere of nitrogen was placed a solution of 5-bromo-2-methylpyrimidine $(184 \mathrm{~g}, 1.06 \mathrm{~mol})$ and $\mathrm{B}(\mathrm{i}-\mathrm{PrO})_{3}(240 \mathrm{~g}, 1.28 \mathrm{~mol})$ in THF/toluene $(3 / 3 \mathrm{~L})$. This was followed by the dropwise addition of a $2.5 \mathrm{M}$ solution of $\mathrm{n}-\mathrm{BuLi}(510 \mathrm{~mL}, 1.28 \mathrm{~mol})$ with stirring at $-78{ }^{\circ} \mathrm{C}$. The resulting solution was stirred for $1 \mathrm{~h}$ at $-78{ }^{\circ} \mathrm{C}$, then quenched by the addition of $200 \mathrm{~mL}$ of aqueous $\mathrm{NH}_{4} \mathrm{Cl}$. The organic phase was dried and concentrated under vacuum. The aqueous phase was adjusted to $\mathrm{pH} 4$ with $\mathrm{AcOH}$. The solid was collected by filtration and dried in an oven under reduced pressure providing (2-methylpyrimidin-5yl)boronic acid (115 g, 78\%).

Step 5: Into a 5-L 4-neck round-bottom flask purged and maintained with an inert atmosphere of nitrogen was placed a solution of 6-chloro-9ethyl-8-iodo-9H-purine (242 g, $784 \mathrm{mmol})$, (2-methylpyrimidin-5-yl)boronic acid (108 g, $783 \mathrm{mmol})$, potassium carbonate (162 g, $1.17 \mathrm{~mol}$ ) and $\mathrm{Pd}(\mathrm{dppf}) \mathrm{Cl}_{2}$-DCM $(32 \mathrm{~g}, 39 \mathrm{mmol})$ in dioxane $(2.4 \mathrm{~L})$ and water $(480 \mathrm{~mL})$. The resulting solution was stirred overnight at $90^{\circ} \mathrm{C}$. The reaction mixture was cooled to room temperature, then extracted with $2 \times 1.5 \mathrm{~L}$ of EtOAc. The organic extracts were combined, dried $\left(\mathrm{MgSO}_{4}\right)$ and concentrated under vacuum. The residue was purified by chromatography on $\mathrm{SiO}_{2}$ (5:1:1 petroleum ether/DCM/EtOAc) providing 6-chloro-9-ethyl-8-(2methylpyrimidin-5-yl)-9H-purine (75 g, 35\%). ${ }^{1} \mathrm{H} \mathrm{NMR}\left(300 \mathrm{MHz}, \mathrm{CDCl}_{3}\right) \delta 9.12(\mathrm{~s}, 2 \mathrm{H}), 8.80(\mathrm{~s}, 1 \mathrm{H}), 4.46$ (q, J = 7.2 Hz, $\left.2 \mathrm{H}\right), 2.89(\mathrm{~s}, 3 \mathrm{H}), 1.57-1.51$ $\left(\mathrm{t}, J=7.2 \mathrm{~Hz}, 3 \mathrm{H}\right.$ ). MS (El) calc'd for $\mathrm{C}_{12} \mathrm{H}_{12} \mathrm{~N}_{6} \mathrm{Cl}[\mathrm{M}+\mathrm{H}]^{+}, 275$; found, 275. 
<smiles>Cc1ncc(-c2nc3c(Cl)ncnc3n2C)cn1</smiles>

6-Chloro-9-methyl-8-(2-methylpyrimidin-5-yl)-9H-purine was prepared in a fashion analogous to 6-chloro-9-ethyl-8-(2-methylpyrimidin-5-yl)-9Hpurine, substituting ethyl iodide for methyl iodide. MS (EI) calc'd for $\mathrm{C}_{11} \mathrm{H}_{10} \mathrm{CIN} 6[\mathrm{M}+\mathrm{H}]^{+}, 261$; found, 261.

(3S)-3-Benzyl-3-methyl-5-(9-methylpurin-6-yl)indolin-2-one (2a L-005454836).<smiles>CC1(Cc2ccccc2)C(=O)Nc2ccc(Br)cc21</smiles>

1) $\mathrm{PdCl}_{2}$ (dppf), $\mathrm{K}_{3} \mathrm{PO}_{4}$ 6-chloro-9-methyl-9H-purine dioxane, water, $80^{\circ} \mathrm{C}$

2) Chiral Separation<smiles>Cn1cnc2c(-c3ccc4c(c3)[C@@](C)(Cc3ccccc3)C(=O)N4)ncnc21</smiles>

Compound $\mathbf{2 a}$ was prepared in a fashion analogous to compound $\mathbf{2 f}$, substituting 6-chloro-9-ethyl-8-(2-methylpyrimidin-5-yl)-9H-purine for 6chloro-9-methyl-9H-purine. The racemic material was then resolved using chiral column chromatography [Column: Phenomenex Lux-4, $21 \times 250$ $\mathrm{mm} ; 220 \mathrm{~nm}$ detection; $70 \mathrm{~mL} / \mathrm{min}$ flow rate; $35 \% \mathrm{MeOH}$ and $0.25 \%$ DMEA in $\mathrm{CO}_{2}$ ]. The faster eluting enantiomer came at a retention time of 4.95 $\min (2 \mathrm{a})$ was collected; while the slower eluting enantiomer came at a retention time of $5.85 \mathrm{~min}$ and was discarded. ${ }^{1} \mathrm{H} \mathrm{NMR}\left(600 \mathrm{MHz}, \mathrm{DMSO}-d_{6}\right)$ $\delta 10.42(\mathrm{~s}, 1 \mathrm{H}), 8.90(\mathrm{~s}, 1 \mathrm{H}), 8.78(\mathrm{~s}, 1 \mathrm{H}), 8.78(\mathrm{~s}, 1 \mathrm{H}), 8.55(\mathrm{~s}, 1 \mathrm{H}), 2.98(\mathrm{~m}, 3 \mathrm{H}), 6.75-6.82(\mathrm{~m}, 3 \mathrm{H}), 3.83(\mathrm{~s}, 3 \mathrm{H}), 3.02-3.12(\mathrm{~m}, 2 \mathrm{H}), 1.40(\mathrm{~s}, 3 \mathrm{H})$; HRMS (EI) calc'd for $\mathrm{C}_{22} \mathrm{H}_{20} \mathrm{~N}_{5} \mathrm{O}[\mathrm{M}+\mathrm{H}]^{+}, 370.1668$; found, 370.1678 .

\section{(3S)-3-(Cyclopropylmethyl)-3-methyl-5-(9-methylpurin-6-yl)indolin-2-one (2b L-005454845).}<smiles>CC1(CC2CC2)C(=O)Nc2ccc(Br)cc21</smiles>

1) $\mathrm{PdCl}_{2}$ (dppf), $\mathrm{K}_{3} \mathrm{PO}_{4}$ 6-chloro-9-methyl-9H-purine dioxane, water, $80^{\circ} \mathrm{C}$

2) Chiral Separation<smiles>Cn1cnc2c(-c3ccc4c(c3)[C@@](C)(CC3CC3)C(=O)N4)ncnc21</smiles>

Compound $\mathbf{2 b}$ was prepared in a fashion analogous to compound $\mathbf{2 e}$, substituting 6-chloro-9-ethyl-8-(2-methylpyrimidin-5-yl)-9H-purine for 6chloro-9-methyl-9H-purine. The racemic material was then resolved using chiral column chromatography [Column: Phenomenex Lux-4, 21x250 $\mathrm{mm} ; 220 \mathrm{~nm}$ detection; $70 \mathrm{~mL} / \mathrm{min}$ flow rate; $30 \% \mathrm{MeOH}$ and $0.25 \%$ DMEA in $\mathrm{CO}_{2}$ ]. The faster eluting enantiomer came at a retention time of 4.95 $\min (\mathbf{2 b})$ was collected; while the slower eluting less active enantiomer came at a retention time of $5.85 \mathrm{~min}$ and was discarded. ${ }^{1} \mathrm{H} \mathrm{NMR}(600 \mathrm{MHz}$, DMSO- $\left.d_{6}\right) \delta 11.68(\mathrm{~s}, 1 \mathrm{H}), 8.85-8.90(\mathrm{~m}, 2 \mathrm{H}), 8.66(\mathrm{~s}, 1 \mathrm{H}), 8.56(\mathrm{~s}, 1 \mathrm{H}), 7.02(\mathrm{~d}, 1 \mathrm{H}), 3.82(\mathrm{~s}, 3 \mathrm{H}), 1.90(\mathrm{~m}, 1 \mathrm{H}), 1.50(\mathrm{~m}, 1 \mathrm{H}), 1.42(\mathrm{~s}, 3 \mathrm{H}), 0.32$ $(\mathrm{m}, 1 \mathrm{H}), 0.20(\mathrm{~m}, 1 \mathrm{H}), 0.09(\mathrm{~m}, 1 \mathrm{H}),-0.03(\mathrm{~m}, 1 \mathrm{H}),-0.09(\mathrm{~m}, 1 \mathrm{H}) ;{ }^{13} \mathrm{C}$ NMR $\left(150 \mathrm{MHz}, \mathrm{DMSO}-d_{6}\right) \delta$ 182.5, 153.1, 153.0, 152.1, 147.0, 145.1, 135.3, 130.8, 130.0, 129.4, 124.1, 109.8, 49.0, 42.8, 30.1, 23.9, 7.1, 4.4, 4.2; HRMS (EI) calc'd for $\mathrm{C}_{19} \mathrm{H}_{20} \mathrm{~N}_{5} \mathrm{O}[\mathrm{M}+\mathrm{H}]^{+}, 334.1668$; found, 334.1680.

\section{(3S)-3-(Cyclopropylmethyl)-5-[8-(1-ethyl-5-methyl-pyrazol-4-yl)-9-methyl-purin-6-yl]-3-methyl-indolin-2-one (2c L-005453808).}

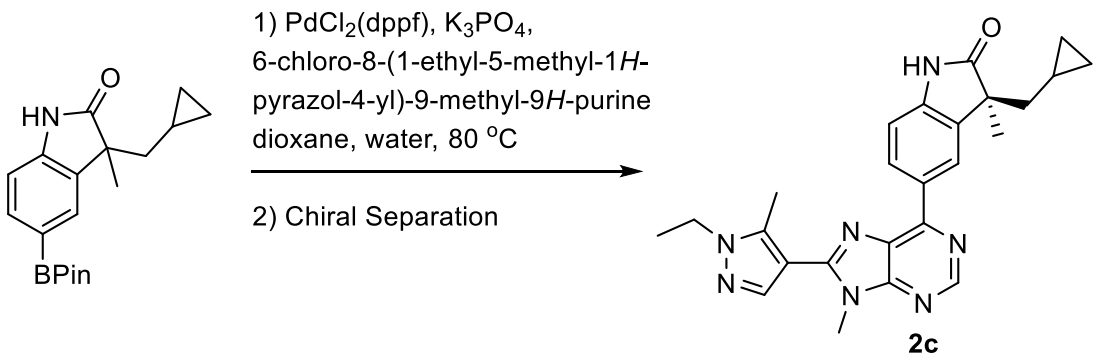


Compound $\mathbf{2 c}$ was prepared in a fashion analogous to $2 \mathrm{e}$, substituting 6-chloro-9-ethyl-8-(2-methylpyrimidin-5-yl)-9H-purine for 6-chloro-8-(1ethyl-5-methyl-1H-pyrazol-4-yl)-9-methyl-9H-purine [for synthesis see Methot, J. L. et al. J. Med. Chem. 2019, 62, 4370-4382.]. The racemic material was then resolved using chiral column chromatography [Column: Chiralpak AD-H, 21x250 mm; $220 \mathrm{~nm}$ detection; $70 \mathrm{~mL} / \mathrm{min}$ flow rate; $35 \% \mathrm{MeOH}$ and $0.25 \% \mathrm{DMEA}_{\text {in }} \mathrm{CO}_{2}$ ]. The faster eluting enantiomer came at a retention time of 3.85 min (2c) was collected; while the slower eluting less active enantiomer came at a retention time of $4.68 \mathrm{~min}$ and was discarded. ${ }^{1} \mathrm{H} \mathrm{NMR}\left(600 \mathrm{MHz}, \mathrm{DMSO}-d_{6}\right) \delta 11.68(\mathrm{~s}, 1 \mathrm{H}), 8.88(\mathrm{~s}, 1 \mathrm{H})$, $8.82(\mathrm{~s}, 1 \mathrm{H}), 8.75(\mathrm{~d}, 1 \mathrm{H}), 8.12(\mathrm{~s}, 1 \mathrm{H}), 7.02(\mathrm{~d}, 1 \mathrm{H}), 4.20(\mathrm{~m}, 2 \mathrm{H}), 3.92(\mathrm{~s}, 3 \mathrm{H}), 2.71(\mathrm{~s}, 3 \mathrm{H}), 1.83(\mathrm{~m}, 1 \mathrm{H}), 1.56(\mathrm{~m}, 1 \mathrm{H}), 1.37(\mathrm{t}, 3 \mathrm{H}), 1.18(\mathrm{~s}, 3 \mathrm{H})$, $0.35(\mathrm{~m}, 1 \mathrm{H}), 0.18(\mathrm{~m}, 1 \mathrm{H}), 0.11(\mathrm{~m}, 1 \mathrm{H}),-0.03(\mathrm{~m}, 1 \mathrm{H}),-0.16(\mathrm{~m}, 1 \mathrm{H}) ;{ }^{13} \mathrm{C} N M R\left(125 \mathrm{MHz}, \mathrm{DMSO}-d_{6}\right) \delta$ 182.5, 154.0, 151.3, 151.1, 150.5, 144.8,

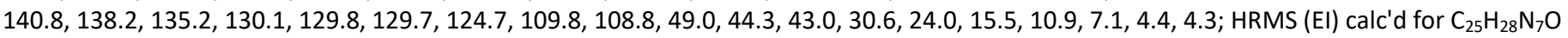
$[\mathrm{M}+\mathrm{H}]^{+}, 442.2355$; found, 442.2355 .

\section{(3S)-3-(Cyclopropylmethyl)-3-methyl-5-[9-methyl-8-(2-methylpyrimidin-5-yl)purin-6-yl]indolin-2-one (2d L-005454840).}

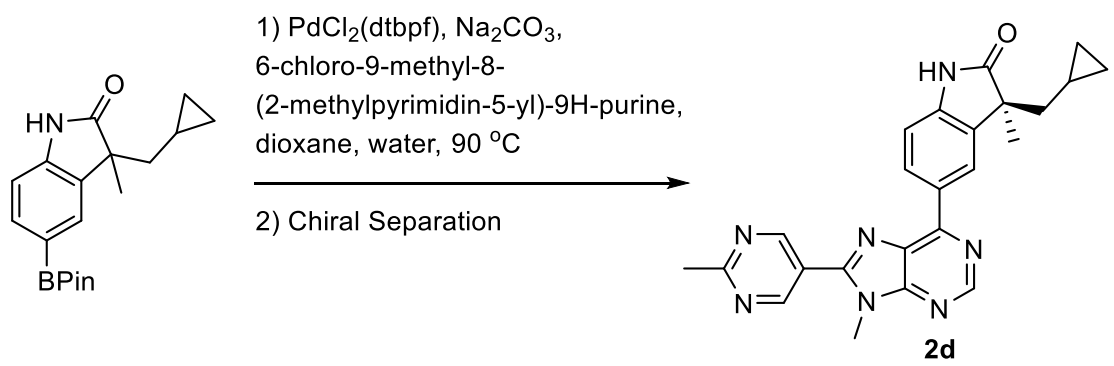

Compound $\mathbf{2 d}$ was prepared in a fashion analogous to $\mathbf{2 e}$, substituting 6-chloro-9-ethyl-8-(2-methylpyrimidin-5-yl)-9H-purine for 6-chloro-9-methyl8-(2-methylpyrimidin-5-yl)-9H-purine. The racemic material was then resolved using chiral column chromatography [Column: Chiralpak AS-H, $21 \times 250 \mathrm{~mm} ; 220 \mathrm{~nm}$ detection; $70 \mathrm{~mL} / \mathrm{min}$ flow rate; $35 \% \mathrm{MeOH}$ and $0.25 \%$ DMEA in $\mathrm{CO}_{2}$ ]. The faster eluting enantiomer came at a retention time of $3.77 \mathrm{~min}$ was discarded; while the slower eluting and more active enantiomer (2d) came at a retention time of $5.17 \mathrm{~min}$. HRMS (EI) calc'd for $\mathrm{C}_{24} \mathrm{H}_{24} \mathrm{~N} 7 \mathrm{O}[\mathrm{M}+\mathrm{H}]^{+}, 426.2042$; found, 426.2054 .

\section{(3S)-3-(Cyclopropylmethyl)-5-[9-ethyl-8-(2-methylpyrimidin-5-yl)purin-3-ium-6-yl]-3-methyl-indolin-2-one (2e L-005442745).}

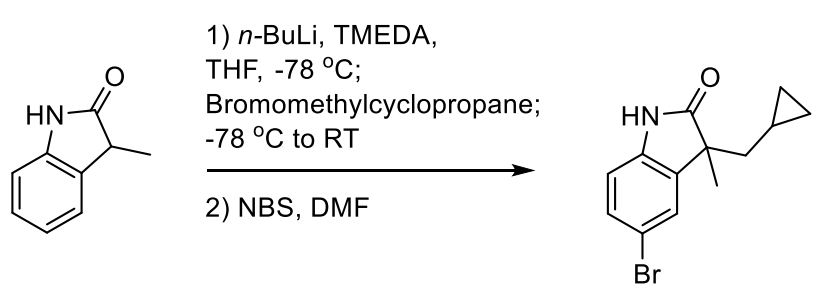

3) (BPin) $)_{2}$, SPhos-Pd, $\mathrm{KOAc}$, dioxane, $85^{\circ} \mathrm{C}$

4) $\mathrm{PdCl}_{2}$ (dtbpf), $\mathrm{Na}_{2} \mathrm{CO}_{3}$, 6-chloro-9-ethyl-8-(2methylpyrimidin-5-yl)-9H-purine, dioxane, water, $90^{\circ} \mathrm{C}$ 5) Chiral Separation

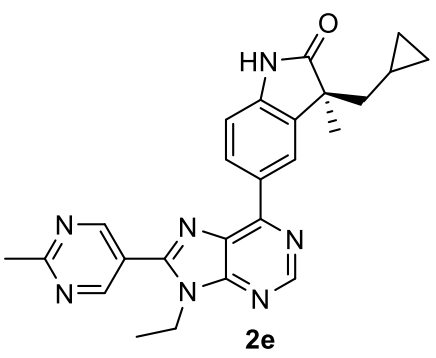

Steps 1-2: A 100-mL round-bottom flask was charged with a solution of 3-methyl-2,3-dihydro-1H-indol-2-one (150 mg, $1.02 \mathrm{mmol})$ in $5 \mathrm{~mL}$ of THF and TMEDA $(0.15 \mathrm{~mL}, 1.0 \mathrm{mmol})$. The mixture was cooled to $-78{ }^{\circ} \mathrm{C}$ and treated with a $2.5 \mathrm{M}$ solution of $\mathrm{n}$-BuLi $(0.90 \mathrm{~mL})$, then stirred for $30 \mathrm{~min}$. Next, (bromomethyl)cyclopropane $\left(0.11 \mathrm{~mL}, 1.1 \mathrm{mmol}\right.$ ) was added dropwise with stirring at $-78{ }^{\circ} \mathrm{C}$. The resulting solution was stirred overnight at $25^{\circ} \mathrm{C}$, and then quenched by the addition of sat. $\mathrm{NH}_{4} \mathrm{Cl}$. The resulting solution was extracted with EtOAc and the combined organic layers dried $\left(\mathrm{MgSO}_{4}\right)$ and concentrated. The residue was purified by chromatography on $\mathrm{SiO}_{2}(10 \%$ to $60 \% \mathrm{EtOAc} /$ hexane) to give the desired product (145 $\mathrm{mg}$, 71\%). MS (EI) calc'd for $\mathrm{C}_{13} \mathrm{H}_{16} \mathrm{NO}[\mathrm{M}+\mathrm{H}]^{+}, 202$; found, 202. A solution of 3-(cyclopropylmethyl)-3-methylindolin-2-one (145 mg, $0.720 \mathrm{mmol}$ ) in $3 \mathrm{~mL}$ of DMF was cooled to $0{ }^{\circ} \mathrm{C}$. N-Bromosuccinimide (133 mg, $0.749 \mathrm{mmol}$ ) was then added, and the resulting solution stirred with slow warming to room temperature overnight. The reaction was diluted with EtOAc and washed with brine. The organic layer was dried $\left(\mathrm{MgSO}_{4}\right)$, filtered and concentrated. The residue was purified by chromatography on $\mathrm{SiO}_{2}(10 \%$ to $60 \% \mathrm{EtOAc} /$ hexane) to give the desired intermediate 5-bromo-3(cyclopropylmethyl)-3-methylindolin-2-one (200 mg, 99\%). MS (EI) calc'd for $\mathrm{C}_{13} \mathrm{H}_{15} \mathrm{BrNO}$ [M+H]+, 282; found, 282.

Steps 3-4: A vial containing 5-bromo-3-(cyclopropylmethyl)-3-methylindolin-2-one (270 mg, $0.97 \mathrm{mmol}), \mathrm{B}(\mathrm{Pin}) 2$ (296 mg, $1.17 \mathrm{mmol}), \mathrm{KOAc}(238$ $\mathrm{mg}, 2.43 \mathrm{mmol})$, SPhos precatalyst $\left(76 \mathrm{mg}, 0.097 \mathrm{mmol}\right.$ ) in $4 \mathrm{~mL}$ of dioxane was purged with nitrogen and stirred at $85^{\circ} \mathrm{C}$ for $2 \mathrm{~h}$. The mixture was filtered through a pad of celite and concentrated to afford a residue which was purified by chromatography on $\mathrm{SiO}_{2}(2 \%$ to $20 \%$ EtOAc/hexane) to give the desired product. $\mathrm{MS}$ (EI) calc'd for $\mathrm{C}_{19} \mathrm{H}_{27} \mathrm{BNO}_{3}[\mathrm{M}+\mathrm{H}]^{+}, 328$; found, 328. A mixture of 3-(cyclopropylmethyl)-3-methyl-5-(4,4,5,5tetramethyl-1,3,2-dioxaborolan-2-yl)indolin-2-one (70 mg, $0.21 \mathrm{mmol}), 6$-chloro-9-ethyl-8-(2-methylpyrimidin-5-yl)-9H-purine (59 mg, $0.21 \mathrm{mmol})$ and $\mathrm{PdCl}_{2}$ (dtbpf) $(19 \mathrm{mg}, 0.021 \mathrm{mmol})$ in $1.5 \mathrm{~mL}$ of 1,4-dioxane and $2 \mathrm{M}$ aqueous sodium carbonate $(0.2 \mathrm{ml}, 0.4 \mathrm{mmol})$ was stirred at reflux under argon for overnight. The reaction mixture was partitioned between DCM and water. The organic layer was dried $\left(\mathrm{Na}_{2} \mathrm{SO}_{4}\right)$, filtered and concentrated. The residue was purified by reverse phase chromatography (MeCN/water gradient with $0.1 \%$ TFA modifier) to provide the racemic product. MS (EI) calc'd for $\mathrm{C}_{25} \mathrm{H}_{26} \mathrm{~N}_{7} \mathrm{O}[\mathrm{M}+\mathrm{H}]^{+}, 440$; found, 440 . 
Step 5: The final product was resolved using chiral column chromatography [Column: Chiralpak AS-H, $21 \times 250 \mathrm{~mm} ; 220 \mathrm{~nm}$ detection; $70 \mathrm{~mL} / \mathrm{min}$ flow rate; $30 \% \mathrm{MeOH}$ and $0.25 \% \mathrm{Me}_{2} \mathrm{NEt}$ in $\mathrm{CO}_{2}$ ]. The faster eluting enantiomer came at a retention time of 3.49 min and was discarded. The desired slower eluting enantiomer came at a retention time of $4.45 \mathrm{~min}(\mathbf{2 e}):{ }^{1} \mathrm{H} \mathrm{NMR}\left(600 \mathrm{MHz}, \mathrm{DMSO}-d_{6}\right) \delta 10.72(\mathrm{~s}, 1 \mathrm{H}), 9.24(\mathrm{~s}, 2 \mathrm{H}), 8.97(\mathrm{~s}, 1 \mathrm{H}), 8.92$ $(\mathrm{d}, J=8.3 \mathrm{~Hz}, 1 \mathrm{H}), 8.72(\mathrm{~s}, 1 \mathrm{H}), 7.07(\mathrm{~d}, J=8.2 \mathrm{~Hz}, 1 \mathrm{H}), 4.44(\mathrm{q}, J=7.3 \mathrm{~Hz}, 2 \mathrm{H}), 2.78(\mathrm{~s}, 3 \mathrm{H}), 1.92(\mathrm{dd}, J=13.9,6.0 \mathrm{~Hz}, 1 \mathrm{H}), 1.56(\mathrm{dd}, J=13.9,7.7 \mathrm{~Hz}$, $1 \mathrm{H}), 1.38(\mathrm{t}, J=7.2 \mathrm{~Hz}, 3 \mathrm{H}), 1.32(\mathrm{~s}, 3 \mathrm{H}), 1.15(\mathrm{dt}, J=18.8,7.3 \mathrm{~Hz}, 1 \mathrm{H}), 0.35(\mathrm{~d}, J=8.6 \mathrm{~Hz}, 1 \mathrm{H}),-0.1-0.23(\mathrm{~m}, 3 \mathrm{H}) ;{ }^{13} \mathrm{C} \mathrm{NMR}\left(125 \mathrm{MHz}, \mathrm{DMSO}-d_{6}\right) \delta$ 182.5, 169.4, 157.4 (2C), 153.9, 153.4, 152.5, 150.0, 145.3, 135.4, 131.0, 130.2, 129.2, 124.2, 121.9, 109.9, 49.0, 42.8, 39.3, 26.3, 23.8, 15.3, 7.0, 4.4, 4.3; HRMS (EI) calc'd for $\mathrm{C}_{25} \mathrm{H}_{26} \mathrm{~N}_{7} \mathrm{O}[\mathrm{M}+\mathrm{H}]^{+}, 440.2199$; found, 440.2192.

\section{(3S)-3-Benzyl-5-[9-ethyl-8-(2-methylpyrimidin-5-yl)purin-6-yl]-3-methyl-indolin-2-one (2f L-005434267).}

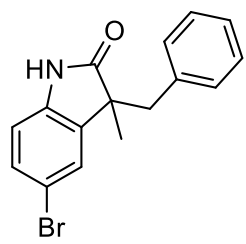

1) $(\mathrm{BPin})_{2}, \mathrm{PdCl}_{2}$ (dppf), KOAc, dioxane, $80^{\circ} \mathrm{C}$

2) $\mathrm{PdCl}_{2}(\mathrm{dppf}), \mathrm{K}_{3} \mathrm{PO}_{4}$, 6-chloro-9-ethyl-8-(2methylpyrimidin-5-yl)-9H-purine, dioxane, water, $80^{\circ} \mathrm{C}$

3) Chiral Separation

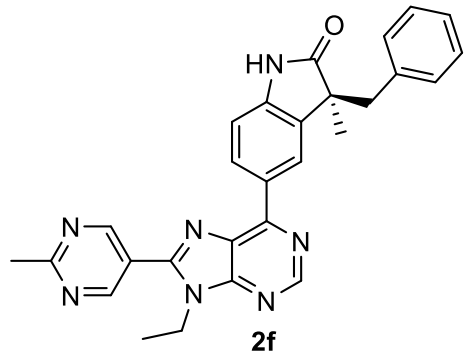

Step 1: Oxindole 3-benzyl-5-bromo-3-methylindolin-2-one was prepared in a fashion analogous to 3-methyl-3-(oxetan-3-ylmethyl)indolin-2-one used for the synthesis of $\mathbf{2 i}$. In this case, 3-iodomethyloxetane is replaced by benzyl bromide. A mixture of 3-benzyl-5-bromo-3-methylindolin-2-one (100 $\mathrm{mg}, 0.316 \mathrm{mmol}$ ) in dioxane $(1 \mathrm{~mL})$ was treated with (BPin) ${ }_{2}(120 \mathrm{mg}, 0.47 \mathrm{mmol}), \mathrm{KOAc}(100 \mathrm{mg}, 1.0 \mathrm{mmol})$ and PdCl${ }_{2} \mathrm{dppf}(20 \mathrm{mg}, 0.027 \mathrm{mmol})$. The mixture was stirred at $100{ }^{\circ} \mathrm{C}$ for 3 hours, cooled, diluted with $\mathrm{DCM}$, washed with water, dried $\left(\mathrm{Na}_{2} \mathrm{SO}_{4}\right)$ and concentrated. Chromatography on $\mathrm{SiO}{ }_{2}$ (0-100\% EtOAC/DCM) gave 3-benzyl-3-methyl-5-(4,4,5,5-tetramethyl-1,3,2-dioxaborolan-2-yl)indolin-2-one (110 mg, 96\%). MS (EI) calc'd for $\mathrm{C}_{22} \mathrm{H}_{27} \mathrm{BNO}_{3}[\mathrm{M}+\mathrm{H}]^{+}, 364$; found, 364.

Step 2: A solution of 3-benzyl-3-methyl-5-(4,4,5,5-tetramethyl-1,3,2-dioxaborolan-2-yl)indolin-2-one (50 mg, 0.14 mmol), 6-chloro-9-ethyl-8-(2methylpyrimidin-5-yl)-9H-purine $(75 \mathrm{mg}, 0.27 \mathrm{mmol})$ in $1 \mathrm{~mL}$ of dioxane and $0.2 \mathrm{~mL}$ of water was treated with $\mathrm{PdCl}_{2}(\mathrm{dppf})(10 \mathrm{mg}, 0.012 \mathrm{mmol})$ and $\mathrm{K}_{3} \mathrm{PO}_{4}(50 \mathrm{mg}, 0.24 \mathrm{mmol})$. The reaction mixture was stirred for 2 hours at $80^{\circ} \mathrm{C}$, cooled, filtered and concentrated. The residue was purified by reverse phase chromatography (MeCN/water with $0.1 \%$ TFA) to provide racemic 3-benzyl-5-(9-ethyl-8-(2-methylpyrimidin-5-yl)-9H-purin-6-yl)-3methylindolin-2-one (40 mg, 61\%). MS (El) calc'd for $\mathrm{C}_{28} \mathrm{H}_{26} \mathrm{~N}_{7} \mathrm{O}[\mathrm{M}+\mathrm{H}]^{+}, 476$; found, 476.

Step 3: The racemic material was then dissolved in $2 \mathrm{~mL}$ of DMF and resolved using chiral column chromatography [Column: Chiralpak IB, $21 \times 250$ $\mathrm{mm} ; 220 \mathrm{~nm}$ detection; $70 \mathrm{~mL} / \mathrm{min}$ flow rate; $25 \% \mathrm{MeOH}$ and $0.25 \% \mathrm{Me}_{2} \mathrm{NEt}$ in $\mathrm{CO}_{2}$ ]. The faster eluting less active enantiomer came at a retention time of $5.46 \mathrm{~min}$ and was discarded. The slower eluting more active enantiomer came at a retention time of 6.09 min and was collected.

Characterization data for compound $2 \mathrm{ff}:[\alpha]_{\mathrm{D}}-18^{\circ}(c=2.5 \mathrm{mg} / \mathrm{mL}, \mathrm{MeOH}) ;{ }^{1} \mathrm{H} \mathrm{NMR}\left(600 \mathrm{MHz}, \mathrm{DMSO}-d_{6}\right) \delta 10.51(\mathrm{~s}, 1 \mathrm{H}), 9.22(\mathrm{~s}, 2 \mathrm{H}), 8.96(\mathrm{~s}, 1 \mathrm{H})$, $8.78(\mathrm{~d}, J=7.9 \mathrm{~Hz}, 1 \mathrm{H}), 8.74(\mathrm{~m}, 1 \mathrm{H}), 6.98(\mathrm{~m}, 3 \mathrm{H}), 6.80-6.85(\mathrm{~m}, 3 \mathrm{H}), 4.43(\mathrm{~m}, 2 \mathrm{H}), 3.13(\mathrm{~d}, J=13 \mathrm{~Hz}, 1 \mathrm{H}), 3.03(\mathrm{~d}, J=13 \mathrm{~Hz}, 1 \mathrm{H}), 2.74(\mathrm{~s}, 3 \mathrm{H})$, $1.41(\mathrm{~s}, 3 \mathrm{H}), 1.36$ (t, $J=7.0 \mathrm{~Hz}, 3 \mathrm{H}) ;{ }^{13} \mathrm{C}$ NMR $\left(125 \mathrm{MHz}\right.$, DMSO- $\left.d_{6}\right) \delta 181.6,169.4,157.4(2 \mathrm{C}), 154.0,153.5,152.5,150.0,145.0,137.0,134.2,131.0$ (2C), 130.2, 130.0, 129.1, 128.1 (2C), 126.8, 124.8, 121.9, 109.8, 50.3, 43.6, 41.8, 26.3, 24.3, 15.3; HRMS (EI) calc'd for $\mathrm{C}_{28} \mathrm{H}_{26} \mathrm{~N}_{7} \mathrm{O}[\mathrm{M}+\mathrm{H}]^{+}, 476.2199$; found, 476.2198 .

(3S)-3-Benzyl-5-[9-ethyl-8-(2-methylpyrimidin-5-yl)purin-6-yl]-3-methyl-isoindolin-1-one (2g L-005460077).<smiles>CC(C)(C)OC(=O)N1Cc2cc(Br)ccc2C1=O</smiles>

1) NaHMDS, Mel, $\mathrm{THF},-78^{\circ} \mathrm{C}$

2) NaHMDS, BnBr, $\mathrm{THF},-78^{\circ} \mathrm{C}$

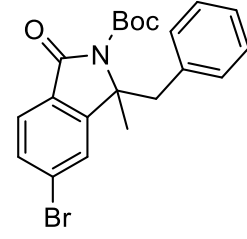

3) $\mathrm{Pd}(\mathrm{dppf}) \mathrm{Cl}_{2}, \mathrm{KOAc},(\mathrm{BPin})_{2}$, dioxane; $90^{\circ} \mathrm{C}$ 4) $\mathrm{Pd}$ (dppf) $\mathrm{Cl}_{2}, \mathrm{~K}_{3} \mathrm{PO}_{4}, 6$-chloro-9-ethyl-8-(2methylpyrimidin-5-yl)-9H-purine, dioxane, water, $80^{\circ} \mathrm{C}$

5) TFA, DCM

6) Chiral separation

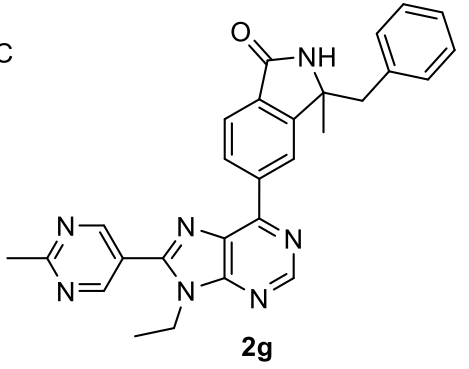

$2 \mathrm{~g}$

Steps 1-2: A solution of tert-butyl 5-bromo-1-oxoisoindoline-2-carboxylate $(0.50 \mathrm{~g}, 1.60 \mathrm{mmol})$ in THF $\left(10 \mathrm{~mL}\right.$ was treated at - $78{ }^{\circ} \mathrm{C}$ with a $1 \mathrm{M}$ THF solution of NaHMDS $(2.0 \mathrm{~mL}, 2.0 \mathrm{mmol})$, the reaction was stirred for $10 \mathrm{~min}$, then treated with Mel $(0.20 \mathrm{~mL}, 3.20 \mathrm{mmol})$. The mixture was stirred for 1 hour at $-78{ }^{\circ} \mathrm{C}$. Quenched with water, extracted with EtOAc. Dried $\left(\mathrm{Na}_{2} \mathrm{SO}_{4}\right)$ and concentrated. Chromatography on $\mathrm{SiO}{ }_{2}(0-100 \%$ EtOAc/DCM) gave the desired product $(375 \mathrm{mg})$. The intermediate was redissolved in THF $(10 \mathrm{~mL})$ and treated at $-78{ }^{\circ} \mathrm{C}$ with NaHMDS $(2.0 \mathrm{~mL}, 2.0$ $\mathrm{mmol})$. The mixture was stirred for $5 \mathrm{~min}$, then treated with $\mathrm{BnBr}(0.41 \mathrm{~g}, 2.4 \mathrm{mmol})$. The reaction mixture was stirred at $-78{ }^{\circ} \mathrm{C}$ for $1 \mathrm{hour}$. Quenched with EtOAc and washed with water. Dried $\left(\mathrm{Na}_{2} \mathrm{SO}_{4}\right)$ filtered and conc. Chromatography on $\mathrm{SiO}_{2}(0-100 \%$ EtOAc/DCM) gave the desired Boc-protected intermediate (150 mg, 22\%). MS (EI) calc'd for $\mathrm{C}_{21} \mathrm{H}_{24} \mathrm{BrNO}_{3}[\mathrm{M}+\mathrm{H}]^{+}, 436,438$; found, 436, 438. 
Steps 3-6: A mixture containing tert-butyl 1-benzyl-6-bromo-1-methyl-3-oxoisoindoline-2-carboxylate (75 mg, $0.19 \mathrm{mmol})$ in dioxane (1 mL) was treated with KOAC $(40 \mathrm{mg}, 0.41 \mathrm{mmol}),(\mathrm{BPin})_{2}(75 \mathrm{mg}, 0.30 \mathrm{mmol}), \mathrm{PdCl}_{2}(\mathrm{dppf})(15 \mathrm{mg}, 0.018 \mathrm{mmol})$ and stirred for $2 \mathrm{hours}$ at $90{ }^{\circ} \mathrm{C}$. Next, 6 chloro-9-ethyl-8-(2-methylpyrimidin-5-yl)- $9 \mathrm{H}$-purine $(50 \mathrm{mg}, 0.18 \mathrm{mmol}), \mathrm{K}_{3} \mathrm{PO}_{4}(100 \mathrm{mg}, 0.47 \mathrm{mmol})$ and water $(0.2 \mathrm{~mL})$ were added and the reaction mixture stirred overnight at $80^{\circ} \mathrm{C}$. The reaction was cooled to RT, diluted with $\mathrm{DCM}$, washed with water, dried $\left(\mathrm{Na}_{2} \mathrm{SO}_{4}\right)$ and concentrated. Chromatography on $\mathrm{SiO}_{2}(0-20 \% \mathrm{MeOH} / \mathrm{DCM})$ gave the desired intermediate product. The residue was dissolved in $1 \mathrm{~mL}$ of $1: 1 \mathrm{DCM} / \mathrm{TFA}$ and stirred for 2 hours, then concentrated to dryness. Reverse phase chromatography (MeCN/water using $0.1 \%$ TFA) provided the desired product as a TFA salt. MS (EI) calc'd for $\mathrm{C}_{28} \mathrm{H}_{26} \mathrm{~N}_{7} \mathrm{O}[\mathrm{M}+\mathrm{H}]+, 476$; found, 476. The racemic material was then dissolved in $4 \mathrm{~mL}$ of $\mathrm{MeOH} / \mathrm{MeCN}$ and resolved using chiral column chromatography [Column: Chiralpak IA, 21x250 mm; $220 \mathrm{~nm}$ detection; $70 \mathrm{~mL} / \mathrm{min}$ flow rate; $40 \% \mathrm{MeOH}, 0.25 \% \mathrm{Me}$ NEt in $\mathrm{CO}_{2}$ ]. The faster eluting and more active enantiomer came at a retention time of $6.10 \mathrm{~min}(\mathbf{2 g})$; while the slower eluting less active enantiomer came at a retention time of $8.41 \mathrm{~min}$. Data for $2 \mathrm{~g}$ : ${ }^{1} \mathrm{H}$ NMR $\left(600 \mathrm{MHz}, \mathrm{DMSO}-\mathrm{d}_{6}\right) \delta 9.25(\mathrm{~s}, 2 \mathrm{H}), 9.10(\mathrm{~s}, 1 \mathrm{H}), 9.00(\mathrm{~s}, 1 \mathrm{H}), 8.87(\mathrm{dd}, \mathrm{J}=7.9,1.2 \mathrm{~Hz}, 1$ H), $8.77(\mathrm{~s}, 1 \mathrm{H}), 7.55(\mathrm{~d}, J=7.9 \mathrm{~Hz}, 1 \mathrm{H}), 6.98-6.97(\mathrm{~m}, 3 \mathrm{H}), 6.90-6.88(\mathrm{~m}, 2 \mathrm{H}), 4.46(\mathrm{q}, J=7.3 \mathrm{~Hz}, 2 \mathrm{H}), 3.30-3.27(\mathrm{~m}, 1 \mathrm{H}), 3.13-3.09(\mathrm{~m}, 1 \mathrm{H}), 2.75$ $(\mathrm{s}, 3 \mathrm{H}), 1.61(\mathrm{~s}, 3 \mathrm{H}), 1.39(\mathrm{t}, J=7.0 \mathrm{~Hz}, 3 \mathrm{H}) ;{ }^{13} \mathrm{C}$ NMR $\left(150 \mathrm{MHz}, \mathrm{DMSO}-d_{6}\right) \delta 169.6,167.9,157.5(2 \mathrm{C}), 154.5,152.6,152.5,151.4,151.2,138.6$, $136.5,134.7,131.2,130.7$ (2C), 129.9, 127.8 (2C), 126.6, 123.4, 123.3, 121.8, 62.5, 45.4, 39.4, 27.4, 26.3, 15.2; HRMS (EI) calc'd for $\mathrm{C}_{28} \mathrm{H}_{26} \mathrm{~N}_{7} \mathrm{O}$ $[\mathrm{M}+\mathrm{H}]^{+}, 476.2199$; found, 476.2211 .

(3S)-5-[9-Ethyl-8-(2-methylpyrimidin-5-yl)purin-6-yl]-3-methyl-3-phenyl-indolin-2-one (2h L-005452620).<smiles>O=[N+]([O-])c1ccccc1F</smiles><smiles>CCOC(=O)Cc1ccccc1</smiles>

1) $\mathrm{NaH}, \mathrm{DMF}$; $\mathrm{NaH}, \mathrm{Mel}$

2) $\mathrm{Zn}, \mathrm{AcOH}$, $\mathrm{THF}, 80^{\circ} \mathrm{C}$

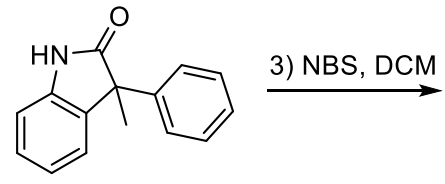<smiles>CC1(c2ccccc2)C(=O)Nc2ccc(Br)cc21</smiles>

4) $\mathrm{PdCl}_{2}$ (dppf), $\mathrm{BPin}_{2}$, $\mathrm{KOAc}$, dioxane, $100^{\circ} \mathrm{C}$;

then add $\mathrm{K}_{3} \mathrm{PO}_{4}$, 6-chloro-9-ethyl-8-(2methylpyrimidin-5-yl)-9H-purine, water, $80^{\circ} \mathrm{C}$ 5) Chiral Separation<smiles>CCn1c(-c2cnc(C)nc2)nc2c(-c3ccc4c(c3)[C@@](C)(c3ccccc3)C(=O)N4)ncnc21</smiles>

Steps 1-2: A solution of ethyl 2-phenylacetate $(2.0 \mathrm{~g}, 12 \mathrm{mmol})$ in $10 \mathrm{~mL}$ of DMF was treated with a $60 \%$ suspension of NaH in mineral oil ( $0.70 \mathrm{~g}$, $18 \mathrm{mmol})$. After stirring for $10 \mathrm{~min}$, the mixture was treated with 1-fluoro-2-nitrobenzene $(2.0 \mathrm{~g}, 14 \mathrm{mmol})$ and stirred for $6 \mathrm{~h}$. The mixture was then treated with more $60 \%$ suspension of $\mathrm{NaH}$ in mineral oil $(0.70 \mathrm{~g}, 18 \mathrm{mmol})$, followed by iodomethane $(1.0 \mathrm{~mL}, 16 \mathrm{mmol})$, and stirred overnight. The mixture was diluted with $\mathrm{DCM}$, washed with water, dried $\left(\mathrm{Na}_{2} \mathrm{SO}_{4}\right)$, and concentrated. The residue was dissolved in $10 \mathrm{~mL}$ of $\mathrm{THF}$ and $10 \mathrm{~mL}$ of $\mathrm{AcOH}$, treated with zinc dust $(4.0 \mathrm{~g}, 61 \mathrm{mmol})$ and warmed to $80^{\circ} \mathrm{C}$. After stirring for $3 \mathrm{~h}$, the mixture was cooled, filtered through a pad of Celite and concentrated. Chromatography on $\mathrm{SiO}_{2}$ (0-40\% EtOAc/DCM) gave the intermediate oxindole (750 mg, 27\%). MS (EI) calc'd for $\mathrm{C}_{15} \mathrm{H}_{14} \mathrm{NO}[\mathrm{M}+\mathrm{H}]^{+}, 224$; found, 224.

Step 3: A mixture containg 3-methyl-3-phenylindolin-2-one (1.12 g, $3.31 \mathrm{mmol})$ in $10 \mathrm{~mL}$ of DCM was treated with NBS (0.70 g, $3.9 \mathrm{mmol})$ and stirred for 1 hour. The mixture was concentrated to dryness and purified by chromatography on $\mathrm{SiO}_{2}$ (0-40\% EtOAc/DCM) to give the bromooxindole (910 mg, 77\%). MS (EI) calc'd for $\mathrm{C}_{15} \mathrm{H}_{13} \mathrm{BrNO}[\mathrm{M}+\mathrm{H}]^{+}, 304$; found, 304.

Steps 4-5: A solution of 5-bromo-3-methyl-3-phenylindolin-2-one ( $75 \mathrm{mg}, 0.25 \mathrm{mmol}$ ) in $1 \mathrm{~mL}$ of dioxane was treated with (BPin) 2 (100 mg, 0.39 $\mathrm{mmol}), \mathrm{KOAC}(50 \mathrm{mg}, 0.51 \mathrm{mmol})$ and $\mathrm{PdCl}_{2}(\mathrm{dppf})(20 \mathrm{mg}, 0.024 \mathrm{mmol})$. The reaction mixture was stirred for 2 hours at $100{ }^{\circ} \mathrm{C}$, then cooled to RT and treated with 6-chloro-9-ethyl-8-(2-methylpyrimidin-5-yl)-9H-purine (70 mg, $0.26 \mathrm{mmol}), \mathrm{K}_{3} \mathrm{PO}_{4}(100 \mathrm{mg}, 0.48 \mathrm{mmol}), \mathrm{PdCl}$ ( $(\mathrm{dppf})(20 \mathrm{mg}, 0.024$ $\mathrm{mmol}$ ) and water $(0.2 \mathrm{~mL})$. The reaction mixture was stirred overnight at $80^{\circ} \mathrm{C}$. Cooled to RT, filtered and purified by reverse phase chromatography (MeCN/water with $0.1 \%$ TFA) to provide the racemic product ( $55 \mathrm{mg}, 38 \%$ ). The racemate was then dissolved in $3.5 \mathrm{~mL}$ of $1: 1$ $\mathrm{MeOH} / \mathrm{MeCN}$ and resolved using chiral column chromatography [Column: Chiralpak AS-H, $21 \times 250 \mathrm{~mm} ; 220 \mathrm{~nm}$ detection; $70 \mathrm{~mL} / \mathrm{min}$ flow rate; $25 \% \mathrm{MeOH}$ and $0.25 \% \mathrm{Me}_{2} \mathrm{NEt}$ in $\mathrm{CO}_{2}$ ]. The faster eluting enantiomer came at a retention time of 7.3 min and was discarded, while the slower eluting enantiomer came at a retention time of $10.2 \mathrm{~min}(\mathbf{2 h})$. Characterization data for compound $\mathbf{2 h}:{ }^{1} \mathrm{H} \mathrm{NMR}\left(600 \mathrm{MHz}, \mathrm{DMSO}-d_{6}\right) \delta 10.89(\mathrm{~s}, 1$ H), $9.19(\mathrm{~s}, 2 \mathrm{H}), 8.94(\mathrm{~d}, J=8.2 \mathrm{~Hz}, 1 \mathrm{H}), 8.90(\mathrm{~s}, 1 \mathrm{H}), 8.55(\mathrm{~s}, 1 \mathrm{H}), 7.32-7.28(\mathrm{~m}, 4 \mathrm{H}), 7.24(\mathrm{~m}, 1 \mathrm{H}), 7.14(\mathrm{~d}, J=8.2 \mathrm{~Hz}, 1 \mathrm{H}), 4.40(\mathrm{q}, J=7.4 \mathrm{~Hz}, 2 \mathrm{H})$, $2.74(\mathrm{~s}, 3 \mathrm{H}), 1.73(\mathrm{~s}, 3 \mathrm{H}), 1.33(\mathrm{t}, J=7.0 \mathrm{~Hz}, 3 \mathrm{H}) ;{ }^{13} \mathrm{C}$ NMR $\left(150 \mathrm{MHz}, \mathrm{DMSO}-d_{6}\right) \delta$ 181.1, 169.4, 157.4 (2C), 154.0, 153.0, 152.5, 150.1, 144.9, 141.5,

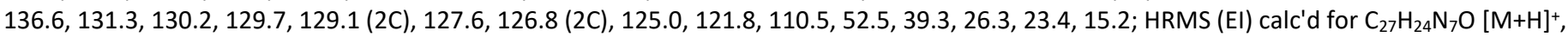
462.2042; found, 462.2049 . 
<smiles>CC1C(=O)Nc2ccccc21</smiles>

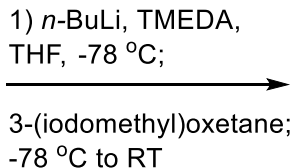

3) $\mathrm{Pd}(\mathrm{dppf}) \mathrm{Cl}_{2}, \mathrm{KOAc}$,

(BPin) 2 , dioxane; $90^{\circ} \mathrm{C}$

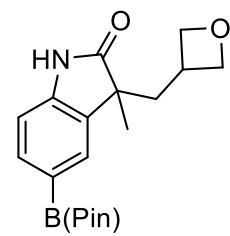

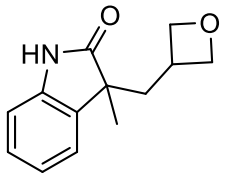

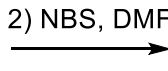

4) $\mathrm{Pd}(\mathrm{dppf}) \mathrm{Cl}_{2}, \mathrm{~K}_{2} \mathrm{CO}_{3}$, 6-chloro-9-ethyl-8-(2methylpyrimidin-5-yl)-9H-purine,

dioxane, $90^{\circ} \mathrm{C}$

5) Chiral separation<smiles>CC1(CC2COC2)C(=O)Nc2ccc(Br)cc21</smiles><smiles>CCn1c(-c2cnc(C)nc2)nc2c(-c3ccc4c(c3)[C@@](C)(CC3COC3)C(=O)N4)ncnc21</smiles>

Step 1: To a solution of $N^{1}, N^{1}, N^{2}, N^{2}$-tetramethylethane-1,2-diamine (160 mg, $\left.1.4 \mathrm{mmol}\right)$ in THF ( $8 \mathrm{~mL}$ ) was added 3-methylindolin-2-one (200 mg, $1.36 \mathrm{mmol}$ ) at $-78{ }^{\circ} \mathrm{C}$. A solution of $n$-butyllithium in hexane $(1.2 \mathrm{~mL}, 3.0 \mathrm{mmol}, 2.50 \mathrm{M})$ was added, and the resulting solution was stirred at $-78{ }^{\circ} \mathrm{C}$ for 30 minutes. 3 -(lodomethyl)oxetane $\left(404 \mathrm{mg}, 2.038 \mathrm{mmol}\right.$ ) was then added to the reaction solution at $-78{ }^{\circ} \mathrm{C}$. The reaction solution then was then slowly warmed to room temperature overnight. The resulting solution was quenched with saturated aqueous ammonia hydrochloride solution. The mixture was extracted with EtOAc $(3 \times 30 \mathrm{~mL})$. The combined organic layers were dried $\left(\mathrm{Na}_{2} \mathrm{SO}_{4}\right)$ and filtered. The filtrate was concentrated under reduced pressure and purified by chromatography on $\mathrm{SiO}_{2}(10 \%$ to $60 \%$ EtOAc/petroleum ether) to afford 3-methyl-3-(oxetan-3ylmethyl)indolin-2-one (200 mg, 78\%). MS (EI) calc'd for $\mathrm{C}_{13} \mathrm{H}_{16} \mathrm{NO}_{2}[\mathrm{M}+\mathrm{H}]^{+}, 218$; found, 218.

Step 2: To a solution of 3-methyl-3-(oxetan-3-ylmethyl)indolin-2-one (150 mg, $0.69 \mathrm{mmol}$ ) in DMF (5 mL), was added NBS (135 mg, $0.759 \mathrm{mmol})$ at $0{ }^{\circ} \mathrm{C}$. The resulting solution was warmed to $25^{\circ} \mathrm{C}$ and stirred for $2 \mathrm{~h}$. The reaction mixture was quenched with saturated sodium bicarbonate (10 $\mathrm{mL})$ and the resulting mixture was extracted with EtOAc $(3 \times 15 \mathrm{~mL})$. The combined organic layers was washed with brine $(3 \times 10 \mathrm{~mL})$, dried $\left(\mathrm{Na}_{2} \mathrm{SO}_{4}\right)$ and filtered. The filtrate was concentrated under reduced pressure. The residue was purified by chromatography on $\mathrm{SiO}_{2}(0$ to $3 \%$ $\mathrm{MeOH} / \mathrm{DCM}$ ) to afford 5-bromo-3-methyl-3-(oxetan-3-ylmethyl)indolin-2-one (200 mg, 98\%). MS (EI) calc'd for $\mathrm{C}_{13} \mathrm{H}_{15} \mathrm{BrNO}_{2}[\mathrm{M}+\mathrm{H}]^{+}, 296$; found, 296.

Step 3-5: A mixture of 5-bromo-3-methyl-3-(oxetan-3-ylmethyl)indolin-2-one (170 mg, $0.574 \mathrm{mmol}$ ), (BPin) 2 (160 mg, $0.631 \mathrm{mmol}$ ), potassium acetate $(141 \mathrm{mg}, 1.44 \mathrm{mmol})$ and $\mathrm{PdCl}_{2}$ (dppf) $(84 \mathrm{mg}, 0.12 \mathrm{mmol})$ in 1,4-dioxane $(2 \mathrm{~mL})$ was deoxygenated with nitrogen, then stirred for $3 \mathrm{~h}$ at 90 ${ }^{\circ} \mathrm{C}$. After cooling to room temperature, 6-chloro-9-ethyl-8-(2-methylpyrimidin-5-yl)-9H-purine, $(173 \mathrm{mg}, 0.631 \mathrm{mmol}), \mathrm{K}_{2} \mathrm{CO}_{3}(159 \mathrm{mg}, 1.15 \mathrm{mmol})$ and water $(0.4 \mathrm{~mL})$ were added to the above mixture, the resulting mixture warmed to $90^{\circ} \mathrm{C}$ and stirred for $16 \mathrm{~h}$. After cooling to room temperature, the reaction mixture was diluted water $(10 \mathrm{~mL})$. The resulting mixture was extracted with EtOAc $(3 \times 15 \mathrm{~mL})$. The combined organic layers was washed with brine $(2 \times 10 \mathrm{~mL})$, dried over anhydrous sodium sulfate and filtered. The filtrate was concentrated under reduced pressure, and the crude product was purified by Prep-TLC with 30:1 DCM/MeOH to afford 5-(9-ethyl-8-(2-methylpyrimidin-5-yl)-9H-purin-6-yl)-3-methyl-3-(oxetan-3ylmethyl)indolin-2-one (50 mg, 19\%). The racemate was separated by Prep-Chiral HPLC [Column: CHIRALPAK IC-3, 2x25cm; 60\% EtOH/hexane; Flow rate: $18 \mathrm{~mL} / \mathrm{min}$; Retention Time 1: $15.9 \mathrm{~min}$; Retention Time 2: $21.7 \mathrm{~min}$. The faster-eluting enantiomer obtained at $15.9 \mathrm{~min}$ was discarded as it is the less active enantiomer. The desired slower-eluting enantiomer $(\mathbf{2 i})$ was obtained at $21.7 \mathrm{~min}$ and was collected: $\left.{ }^{1} \mathrm{H} \mathrm{NMR} \mathrm{(400} \mathrm{MHz,} \mathrm{DMSO-} d_{6}\right) \delta$ $10.76(\mathrm{~s}, 1 \mathrm{H}), 9.26(\mathrm{~s}, 2 \mathrm{H}), 8.99(\mathrm{~s}, 1 \mathrm{H}), 8.93(\mathrm{dd}, J=8.4 \mathrm{~Hz} \& 1.6 \mathrm{~Hz}, 1 \mathrm{H}), 8.65(\mathrm{~d}, J=1.6 \mathrm{~Hz}, 1 \mathrm{H}), 7.07(\mathrm{~d}, J=8.0 \mathrm{~Hz}, 1 \mathrm{H}), 4.44-4.47(\mathrm{~m}, 3 \mathrm{H}), 4.23$ $(\mathrm{t}, J=6.4 \mathrm{~Hz}, 1 \mathrm{H}), 4.10-4.04(\mathrm{~m}, 2 \mathrm{H}), 2.79(\mathrm{~s}, 3 \mathrm{H}), 2.77-2.75(\mathrm{~m}, 1 \mathrm{H}), 2.27-2.15(\mathrm{~m}, 2 \mathrm{H}), 1.39(\mathrm{t}, J=9.2 \mathrm{~Hz}, 3 \mathrm{H}), 1.33(\mathrm{~s}, 3 \mathrm{H}) ;{ }^{13} \mathrm{C} \mathrm{NMR}(150 \mathrm{MHz}$, DMSO- $\left.d_{6}\right) \delta 182.0,169.4,157.4(2 \mathrm{C}), 154.0,153.2,152.5,150.1,144.9,134.4,131.2,130.2,129.4,124.2,121.9,110.1,76.9,76.7,47.6,41.7,39.3$, 32.2, 26.3, 23.5, 15.3; HRMS (EI) calc'd for $\mathrm{C}_{25} \mathrm{H}_{26} \mathrm{~N}_{7} \mathrm{O}_{2}[\mathrm{M}+\mathrm{H}]^{+}$, 456.2148; found, 456.2146.

(3S)-5-[9-Ethyl-8-(2-methylpyrimidin-5-yl)purin-6-yl]-3-methyl-3-(oxetan-2-ylmethyl)indolin-2-one (2j L-005472516).

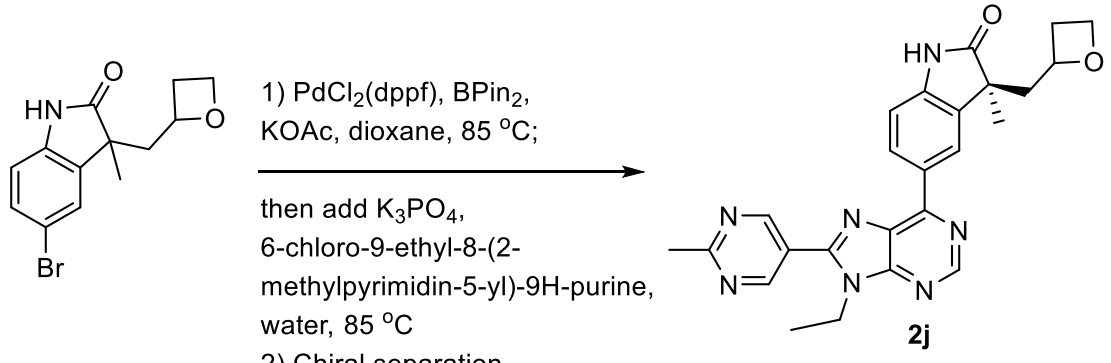

Step 1: 5-Bromo-3-methyl-3-(oxetan-2-ylmethyl)indolin-2-one was prepared in a fashion analogous to the preparation of 5-bromo-3-methyl-3(oxetan-3-ylmethyl)indolin-2-one used for the synthesis of 2i. To a solution of 5-bromo-3-methyl-3-(oxetan-2-ylmethyl)indolin-2-one (200 mg, 0.675 $\mathrm{mmol}$ ) and 4,4,4',4',5,5,5',5'-octamethyl-2,2'-bi(1,3,2-dioxaborolane) (206 mg, $0.810 \mathrm{mmol})$ in 1,4-Dioxane (10 mL) were added KOAc (133 mg, 1.35 $\mathrm{mmol}$ ) and $\mathrm{PdCl}_{2}$ (dppf) ( $25 \mathrm{mg}, 0.034 \mathrm{mmol}$ ) under nitrogen, the mixture was stirred at $85^{\circ} \mathrm{C}$ for $2 \mathrm{~h}$. To above solution were added 6 -chloro-9-ethyl- 
8-(2-methylpyrimidin-5-yl)-9H-purine (204 mg, $0.743 \mathrm{mmol}), \mathrm{K}_{2} \mathrm{CO}_{3}(187 \mathrm{mg}, 1.35 \mathrm{mmol})$ and water $(2 \mathrm{~mL})$, the mixture was stirred $85{ }^{\circ} \mathrm{C}$ for another $2 \mathrm{~h}$. The mixture was cooled to ambient temperature, diluted with water $(5 \mathrm{~mL})$, and extracted with EtOAc $(3 \times 10 \mathrm{~mL})$. The organic layers were combined, dried over anhydrous sodium sulfate, filtered and concentrated. Chromatography on $\mathrm{SiO}_{2}$ (80-95\% EtOAc/hexanes) gave 5-(9-ethyl-8-(2methylpyrimidin-5-yl)-9H-purin-6-yl)-3-methyl-3-(oxetan-2-ylmethyl)indolin-2-one (150 mg, $0.421 \mathrm{mmol}$ ) as a white solid, as a mixture of four stereoisomers.

Step 2: The mixture of four diastereomers were separated using chiral column chromatography [Column: Chiralpak IA, 20x250 mm; $220 \mathrm{~nm}$ detection; $40 \% \mathrm{MeOH}$ and $0.1 \%$ diethylamine in hexane]. Three fractions were collected at 4.8, 5.6 and $8.6 \mathrm{~min}$, and the last fraction (13 mg, $8.6 \mathrm{~min}$ ) was the more potent analog (compound $\mathbf{2 j}$ ). The stereochemistry about the oxetane is unknown. ${ }^{1} \mathrm{H} \mathrm{NMR}\left(300 \mathrm{MHz}, \mathrm{DMSO}-d_{6}\right) \delta 10.64(\mathrm{~s}, 1 \mathrm{H}), 9.27(\mathrm{~s}, 2 \mathrm{H})$, $8.98(\mathrm{~s}, 1 \mathrm{H}), 8.91(\mathrm{~d}, J=8.1 \mathrm{~Hz}, 1 \mathrm{H}), 8.70(\mathrm{~s}, 1 \mathrm{H}), 7.05(\mathrm{~d}, \mathrm{~J}=8.4 \mathrm{~Hz}, 1 \mathrm{H}), 4.40-4.55(\mathrm{~m}, 3 \mathrm{H}), 4.20-4.40(\mathrm{~m}, 2 \mathrm{H}), 2.79(\mathrm{~s}, 3 \mathrm{H}), 2.10-2.30(\mathrm{~m}, 4 \mathrm{H}), 1.40$ $(\mathrm{t}, 3 \mathrm{H}), 1.30$ (s, $3 \mathrm{H}) ;{ }^{13} \mathrm{C}$ NMR $(125 \mathrm{MHz}$, DMSO-d $)$ $\delta 181.9,169.4,157.4$ (2C), 153.9, 153.4, 152.5, 150.1, 145.0, 134.2, 131.2, 130.2, 129.1, 124.5, $121.9,110.0,79.0,67.6,46.4,45.5,40.9,28.5,26.3,24.5,15.3 ; \mathrm{HRMS}$ (EI) calc'd for $\mathrm{C}_{25} \mathrm{H}_{26} \mathrm{~N}_{7} \mathrm{O}_{2}[\mathrm{M}+\mathrm{H}]^{+}, 456.2148 ;$ found, 456.2154 .

\section{(3S)-3-(Cyclobutylamino)-5-[9-ethyl-8-(2-methylpyrimidin-5-yl)purin-6-yl]-3-methyl-indolin-2-one (3a L-005503882).}<smiles>CCn1c(-c2cnc(C)nc2)nc2c(-c3ccc4c(c3)C(C)C(=O)N4)ncnc21</smiles>

Compound 3a was prepared via the method described for the synthesis of 3e, substititing 3-methoxy-3-methylazetidine for cyclobutyl amine. The racemic material was resolved using chiral column chromatography [Column: Chiralpak OJ-H; $21 \times 250 \mathrm{~mm}, 220 \mathrm{~nm}$ detection; $70 \mathrm{~mL} / \mathrm{min}$ flow rate; $20 \% \mathrm{MeOH} / \mathrm{CO}_{2}$ with $0.25 \% \mathrm{Et}_{2} \mathrm{NH}$ ]. The faster eluting and less active enantiomer came at a retention time of 2.96 min, while the slower eluting more active enantiomer (3a) came at a retention time of $3.55 \mathrm{~min}$. Data for $3 \mathrm{a}:{ }^{1} \mathrm{H} \mathrm{NMR}\left(600 \mathrm{MHz}, \mathrm{DMSO}-\mathrm{d}_{6}\right) \delta 10.20(\mathrm{~s}, 1 \mathrm{H}), 9.20(\mathrm{~s}, 2 \mathrm{H}), 8.90(\mathrm{~s}$, $1 \mathrm{H}), 8.85(\mathrm{~d}, 1 \mathrm{H}), 8.64(\mathrm{~s}, 1 \mathrm{H}), 6.97(\mathrm{~d}, 1 \mathrm{H}), 4.42(\mathrm{~m}, 2 \mathrm{H}), 2.88(\mathrm{~m}, 1 \mathrm{H}), 2.80(\mathrm{~m}, 1 \mathrm{H}), 2.76(\mathrm{~s}, 3 \mathrm{H}), 1.83(\mathrm{~m}, 1 \mathrm{H}), 1.63(\mathrm{~m}, 1 \mathrm{H}), 1.58(\mathrm{~m}, 2 \mathrm{H}), 1.30-$ $1.40(\mathrm{~m}, 7 \mathrm{H}) ;{ }^{13} \mathrm{C}$ NMR $\left(150 \mathrm{MHz}\right.$, DMSO- $\left.d_{6}\right) \delta$ 182.4, 169.4, $157.4(2 \mathrm{C}), 154.0,153.3,152.5,150.1,144.9,133.6,131.6,130.2,129.4,125.1,121.9$, $110.1,62.1,50.8,39.3,32.6,32.3,26.3,25.4,15.3,15.1$; HRMS (EI) calc'd for $\mathrm{C}_{25} \mathrm{H}_{27} \mathrm{~N}_{8} \mathrm{O}[\mathrm{M}+\mathrm{H}]^{+}, 455.2308$; found, 455.2317.

(3S)-5-[9-Ethyl-8-(2-methylpyrimidin-5-yl)purin-6-yl]-3-methyl-3-[[(3S)-tetrahydrofuran-3-yl]amino]indolin-2-one (3b L-005483912).
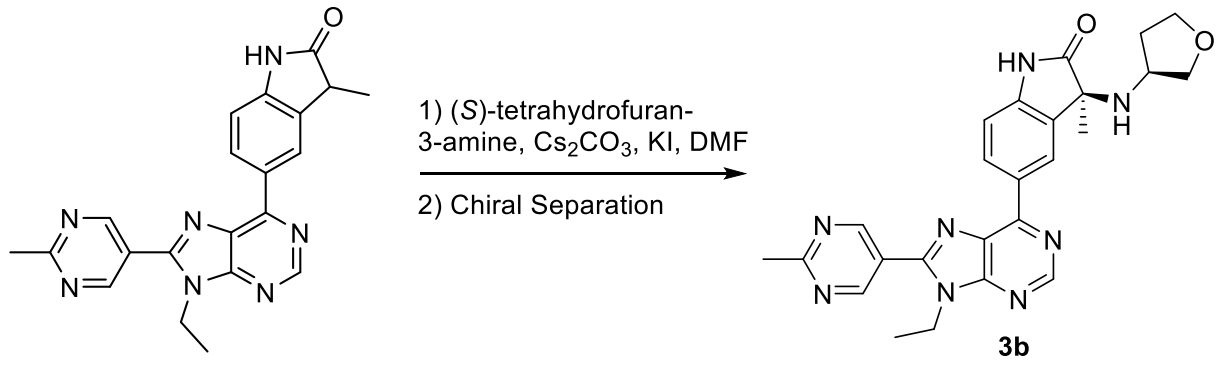

Compound $\mathbf{3 b}$ was prepared via the method described for the synthesis of 3e, substititing 3-methoxy-3-methylazetidine for (S)-tetrahydrofuran-3amine. The racemic material was then dissolved in $\mathrm{MeOH} / \mathrm{MeCN}$ and resolved using chiral column chromatography [Column: Chiralpak OJ-H, 21x250 $\mathrm{mm} ; 220 \mathrm{~nm}$ detection; $70 \mathrm{~mL} / \mathrm{min}$ flow rate; $25 \% \mathrm{MeOH}$ and $0.25 \% \mathrm{Me}_{2} \mathrm{NEt}$ in $\mathrm{CO}_{2}$ ]. The faster eluting and less active enantiomer came at a retention time of $2.22 \mathrm{~min}$; while the slower eluting more active enantiomer came at a retention time of $3.54 \mathrm{~min}$ (compound $3 \mathrm{~b}) .{ }^{1} \mathrm{H} \mathrm{NMR}(500 \mathrm{MHz}, \mathrm{DMSO}$ $\left.d_{6}\right) \delta 9.24(\mathrm{~s}, 2 \mathrm{H}), 8.98(\mathrm{~s}, 1 \mathrm{H}), 8.89(\mathrm{dd}, J=8.2,1.7 \mathrm{~Hz}, 1 \mathrm{H}), 8.77(\mathrm{~d}, J=1.5 \mathrm{~Hz}, 1 \mathrm{H}), 7.07(\mathrm{~d}, J=8.2 \mathrm{~Hz}, 1 \mathrm{H}), 6.70(\mathrm{~m}, 1 \mathrm{H}), 4.45(\mathrm{q}, J=7.2 \mathrm{~Hz}, 2 \mathrm{H})$, $3.64-3.53(\mathrm{~m}, 2 \mathrm{H}), 3.41$ (q, J = 7.3 Hz, $1 \mathrm{H}), 3.30$ (dd, J = 8.5, 5.8 Hz, $1 \mathrm{H}), 2.95(\mathrm{dt}, J=12.5,6.2 \mathrm{~Hz}, 1 \mathrm{H}), 2.78(\mathrm{~s}, 3 \mathrm{H}), 2.73(\mathrm{t}, J=6.2 \mathrm{~Hz}, 2 \mathrm{H}), 1.62$ $(\mathrm{dt}, J=13.4,6.7 \mathrm{~Hz}, 1 \mathrm{H}), 1.38(\mathrm{t}, 3 \mathrm{H}), 1.36(\mathrm{~s}, 3 \mathrm{H}) ;{ }^{13} \mathrm{C} \mathrm{NMR}\left(125 \mathrm{MHz}, \mathrm{DMSO}-d_{6}\right) \delta$ 182.3, 169.4, 157.4 (2C), 154.0, 153.2, 152.5, 150.1, 144.8, 133.5, $131.7,130.2,129.5,125.2,121.9,110.4,73.8,66.6,63.0,55.2,39.3,33.6,26.3,25.7,15.3$; HRMS (EI) calc'd for $\mathrm{C}_{25} \mathrm{H}_{27} \mathrm{~N}_{8} \mathrm{O}_{2}[\mathrm{M}+\mathrm{H}]^{+}, 471.2257$; found, 471.2266. 


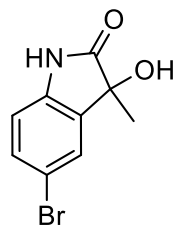

1) $\mathrm{PdCl}_{2}$ (dppf), (BPin) $)_{2}$, $\mathrm{KOAC}$, dioxane, $90^{\circ} \mathrm{C}$

2) $\mathrm{Pd}(\mathrm{dppf}) \mathrm{Cl}_{2}, \mathrm{~K}_{2} \mathrm{CO}_{3}$, 6-chloro-9-ethyl-8-(2methylpyrimidin-5-yl)-9H-purine, dioxane, water, $90^{\circ} \mathrm{C}$
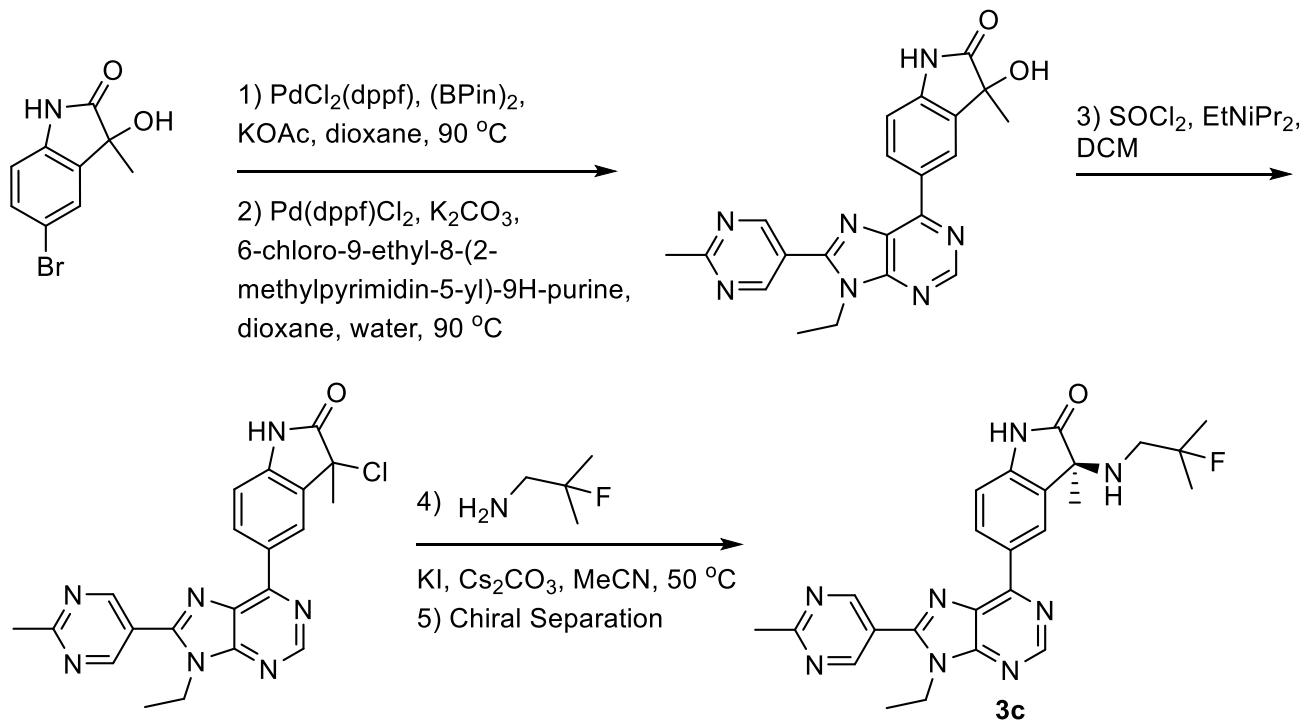

Step 1: A solution of 5-bromo-3-hydroxy-3-methylindolin-2-one ( $8.0 \mathrm{~g}, 33 \mathrm{mmol})$ in $150 \mathrm{~mL}$ of dioxane was treated with (BPin) 2 (10 g, $40 \mathrm{mmol})$, $\operatorname{KOAC}(6.5 \mathrm{~g}, 66 \mathrm{mmol})$ and $\mathrm{PdCl}_{2}(\mathrm{dppf})(2.4 \mathrm{~g}, 3.3 \mathrm{mmol})$. The reaction was warmed to $90{ }^{\circ} \mathrm{C}$ and stirred for 3 hours. Upon cooling to ambient temperature, the reaction mixture was quenched with water $(100 \mathrm{~mL})$ and extracted with DCM $(3 \times 100 \mathrm{~mL})$. The combined organic layers were dried $\left(\mathrm{Na}_{2} \mathrm{SO}_{4}\right)$, filtered and concentrated to dryness. The residue was purified by chromatography on $\mathrm{SiO}_{2}(0-30 \%$ EtOAc/hexanes) to afford 3hydroxy-3-methyl-5-(4,4,5,5-tetramethyl-1,3,2-dioxaborolan-2-yl)indolin-2-one (6.5 g, 65\%). MS (EI) calc'd for $\mathrm{C}_{15} \mathrm{H}_{19} \mathrm{BNO}_{3}\left[\mathrm{M}-\mathrm{H}_{2} \mathrm{O}+\mathrm{H}\right]^{+}, 272$; found, 272.

Step 2: A mixture containing 3-hydroxy-3-methyl-5-(4,4,5,5-tetramethyl-1,3,2-dioxaborolan-2-yl)indolin-2-one (3.0 g, $10 \mathrm{mmol})$ in $50 \mathrm{~mL}$ of dioxane was treated with 6-chloro-9-ethyl-8-(2-methylpyrimidin-5-yl)-9H-purine (2.9 g, $10 \mathrm{mmol}), \mathrm{K}_{2} \mathrm{CO}_{3}(4.3 \mathrm{~g}, 31 \mathrm{mmol})$, water $(5 \mathrm{~mL})$ and PdCl $2(\mathrm{dppf})(0.76$ $\mathrm{g}, 1.0 \mathrm{mmol}$ ). The mixture was stirred at $90{ }^{\circ} \mathrm{C}$ for 3 hours and quenched with $30 \mathrm{~mL}$ of water. The mixture was extracted into EtOAc ( $3 \times 100 \mathrm{~mL}$ ), the combined organic layers were washed with brine and dried $\left(\mathrm{Na}_{2} \mathrm{SO}_{4}\right)$. The solution was concentrated and the residue was purified by chromatography on $\mathrm{SiO}_{2}$ (0-10\% MeOH/DCM) to afford 5-(9-ethyl-8-(2-methylpyrimidin-5-yl)-9H-purin-6-yl)-3-hydroxy-3-methylindolin-2-one (2 g, 43\%). ${ }^{1} \mathrm{H}$ NMR $\left(300 \mathrm{MHz}\right.$, DMSO- $\left.d_{6}\right) \delta 10.60(\mathrm{~s}, 1 \mathrm{H}), 9.26(\mathrm{~s}, 2 \mathrm{H}), 8.99(\mathrm{~s}, 1 \mathrm{H}), 8.95(\mathrm{~d}, J=8.4 \mathrm{~Hz}, 1 \mathrm{H}), 8.82(\mathrm{~s}, 1 \mathrm{H}), 7.05(\mathrm{~d}, J=8.4 \mathrm{~Hz}, 1 \mathrm{H}), 6.06(\mathrm{~s}$, $1 \mathrm{H}), 4.45(\mathrm{q}, J=7.2 \mathrm{~Hz}, 2 \mathrm{H}), 2.80(\mathrm{~s}, 3 \mathrm{H}), 1.49-1.32(\mathrm{~m}, 6 \mathrm{H})$. MS (El) calc'd for $\mathrm{C}_{21} \mathrm{H}_{20} \mathrm{~N}_{7} \mathrm{O}_{2}[\mathrm{M}+\mathrm{H}]^{+}, 402$; found, 402.

Step 3. A solution of 5-(9-ethyl-8-(2-methylpyrimidin-5-yl)-9H-purin-6-yl)-3-hydroxy-3-methylindolin-2-one (300 mg, $0.747 \mathrm{mmol})$ in $10 \mathrm{~mL}$ of $\mathrm{DCM}$ was treated with $\operatorname{EtNiPr}_{2}(0.26 \mathrm{~mL}, 1.5 \mathrm{mmol})$ and $\mathrm{SOCl}_{2}(0.11 \mathrm{ml}, 1.5 \mathrm{mmol})$ at $0{ }^{\circ} \mathrm{C}$. The mixture was stirred at $0{ }^{\circ} \mathrm{C}$ for $3 \mathrm{~h}$ and then quenched with water $(30 \mathrm{~mL})$. The resulting mixture was extracted with EtOAc $(3 \times 20 \mathrm{~mL})$. The combined organic layers were washed with brine $(10 \mathrm{~mL})$, dried $\left(\mathrm{Na}_{2} \mathrm{SO}_{4}\right)$ and concentrated. The residue was purified by chromatography on $\mathrm{SiO}_{2}(0-5 \% \mathrm{MeOH} / \mathrm{DCM})$ to afford 3-chloro-5-(9-ethyl-8-(2methylpyrimidin-5-yl)-9H-purin-6-yl)-3-methylindolin-2-one (300 mg, 91\%). MS (El) calc'd for $\mathrm{C}_{21} \mathrm{H}_{19} \mathrm{ClN}_{7} \mathrm{O}$ [M+H] ${ }^{+}, 420 ;$ found, 420 .

Steps 4-5: To a solution of 3-chloro-5-(9-ethyl-8-(2-methylpyrimidin-5-yl)-9H-purin-6-yl)-3-methylindolin-2-one (50 mg, $0.12 \mathrm{mmol}$ ) in $2 \mathrm{~mL}$ of MeCN were added 2-fluoro-2-methylpropan-1-amine-2,2,2-trifluoroacetate (37 mg, $0.18 \mathrm{mmol})$, cesium carbonate (190 mg, $0.60 \mathrm{mmol})$ and potassium iodide $(20 \mathrm{mg}, 0.12 \mathrm{mmol})$. The reaction mixture was stirred for $3 \mathrm{~h}$ at $50{ }^{\circ} \mathrm{C}$, then quenched with water $(10 \mathrm{~mL})$ and extracted with EtOAc $(3 \times 10$ $\mathrm{mL})$. The combined organic layers were washed with brine $(10 \mathrm{~mL})$, dried $\left(\mathrm{Na}_{2} \mathrm{SO}_{4}\right)$ and concentrated. The crude product was purified by reverse phase chromatography [Column: XSelect CSH Prep C18 OBD, 19x150 mm; 254/220 nm detection; $20 \mathrm{~mL} / \mathrm{min}$ flow rate; $20 \%$ to $39 \%$ MeCN/water with $0.05 \%$ TFA]. The racemic material ( $25 \mathrm{mg}$ ) was then resolved using chiral column chromatography [Column: Chiralpak IC; $20 \times 250 \mathrm{~mm}, 254 \mathrm{~nm}$ detection; $20 \mathrm{~mL} / \mathrm{min}$ flow rate; $30 \% \mathrm{IPA} /$ hexane with $0.2 \% \mathrm{Et}_{2} \mathrm{NH}$. The faster eluting and less active enantiomer came at a retention time of $13 \mathrm{~min}$, while the slower eluting more active enantiomer $(3 \mathrm{c})$ came at a retention time of $18 \mathrm{~min} .[\alpha]_{\mathrm{D}}-31^{\circ}(c=2.5 \mathrm{mg} / \mathrm{mL}, \mathrm{MeOH}) ;{ }^{1} \mathrm{H} \mathrm{NMR}(500 \mathrm{MHz}$, DMSO- $\left.d_{6}\right) \delta 10.72(\mathrm{~s}, 1 \mathrm{H}), 9.23(\mathrm{~s}, 2 \mathrm{H}), 8.99(\mathrm{~s}, 1 \mathrm{H}), 8.90-8.84(\mathrm{~m}, 1 \mathrm{H}), 8.80(\mathrm{~s}, 1 \mathrm{H}), 7.08(\mathrm{~d}, J=8.2 \mathrm{~Hz}, 1 \mathrm{H}), 4.45(\mathrm{q}, J=7.1 \mathrm{~Hz}, 2 \mathrm{H}), 2.79(\mathrm{~s}, 3 \mathrm{H})$, $2.66(\mathrm{dd}, J=10.4,5.7 \mathrm{~Hz}, 1 \mathrm{H}), 2.44(\mathrm{td}, J=12.6,5.7 \mathrm{~Hz}, 1 \mathrm{H}), 1.99(\mathrm{~m}, 1 \mathrm{H}), 1.43-1.37(\mathrm{~m}, 6 \mathrm{H}), 1.18-1.29(\mathrm{~m}, 6 \mathrm{H}) ;{ }^{13} \mathrm{C} \mathrm{NMR}\left(125 \mathrm{MHz}, \mathrm{DMSO}-d_{6}\right) \delta$ $181.4,169.4,157.3$ (2C), 154.0, 153.3, 152.5, 150.1, 145.1, 132.9, 131.5, 130.2, 129.7, 125.1, 121.9, 110.4, 63.0, 52.9, 52.7, 39.3, 26.3, 25.5 (d), 25.3, 24.9 (d), 15.3; HRMS (EI) calc'd for $\mathrm{C}_{25} \mathrm{H}_{28} \mathrm{FN}_{8} \mathrm{O}[\mathrm{M}+\mathrm{H}]^{+}, 475.2370$; found, 475.2363. 


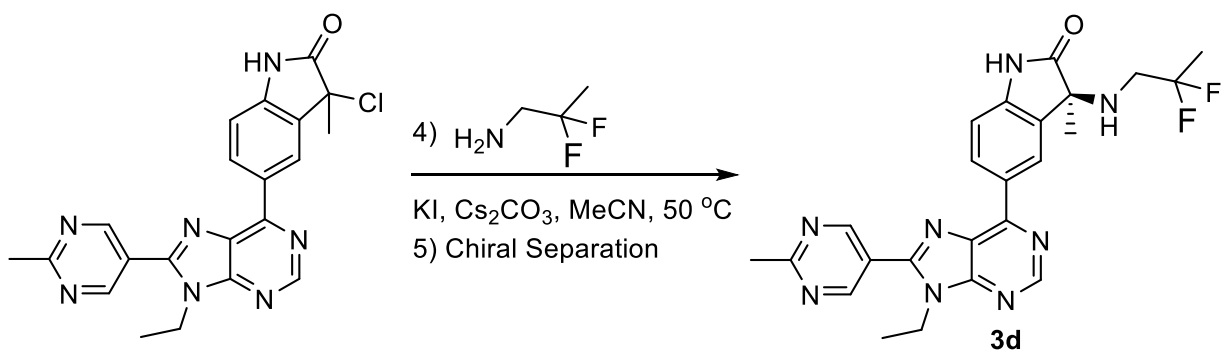

Compound 3d was prepared via the method described for the synthesis of 3c, substituting 2-fluoro-2-methylpropan-1-amine for 2,2-difluoro-propan1-amine. The racemic material was then resolved using chiral column chromatography [Column: Repaired IA; $21 \times 150 \mathrm{~mm} ; 20 \mathrm{~mL} / \mathrm{min}$ flow rate; $10 \% \mathrm{EtOH} /$ hexane]. The faster eluting and more active enantiomer ( $3 \mathrm{~d})$ was collected at $12 \mathrm{~min}$, while the slower eluting and less active enantiomer came at a retention time of $17 \mathrm{~min} .{ }^{1} \mathrm{H}$ NMR $\left(300 \mathrm{MHz}\right.$, DMSO-d $d_{6} \delta 9.20(\mathrm{~s}, 2 \mathrm{H}), 8.92(\mathrm{~s}, 1 \mathrm{H}), 8.81(\mathrm{~d}, J=9 \mathrm{~Hz}, 1 \mathrm{H}), 8.80(\mathrm{~s}, 1 \mathrm{H}), 7.10(\mathrm{~d}, J=9 \mathrm{~Hz}, 1$ $\mathrm{H}), 4.50$ (q, $J=7.5 \mathrm{~Hz}, 2 \mathrm{H}), 2.76(\mathrm{~s}, 3 \mathrm{H}), 2.32$ (q, $J=6 \mathrm{~Hz}, 1 \mathrm{H}), 2.20-2.40(\mathrm{~m}, 1 \mathrm{H}), 1.40-1.60(\mathrm{~m}, 9 \mathrm{H}) ;{ }^{13} \mathrm{C} \mathrm{NMR}\left(125 \mathrm{MHz}, \mathrm{DMSO}-d_{6}\right) \delta 180.9,169.4$, 157.4 (2C), 154.0, 153.2, 152.5, 150.1, 145.0, 132.6, 131.8, 130.2, 129.8, 125.1, 124.3, 121.9, 110.4, 62.8, 49.4, 26.3, 24.9, 21.7, 21.5; 15.3; HRMS (EI) calc'd for $\mathrm{C}_{24} \mathrm{H}_{25} \mathrm{~F}_{2} \mathrm{~N}_{8} \mathrm{O}[\mathrm{M}+\mathrm{H}]^{+}, 479.2119$; found, 479.2126 .

(3S)-5-[9-Ethyl-8-(2-methylpyrimidin-5-yl)purin-6-yl]-3-(3-methoxy-3-methyl-azetidin-1-yl)-3-methyl-indolin-2-one (3e L-005465843).

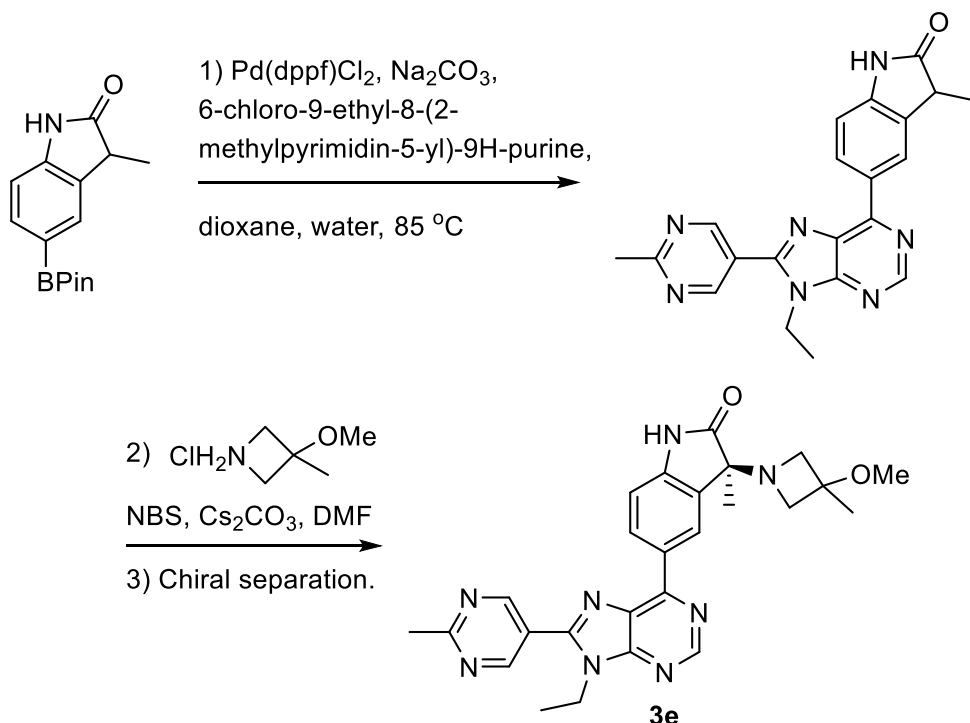

Step 1: A solution of 6-chloro-9-ethyl-8-(2-methylpyrimidin-5-yl)-9H-purine (1.00 g, 3.66 mmol), 3-methyl-5-(4,4,5,5-tetramethyl-1,3,2-dioxaborolan2-yl)indolin-2-one (1.00 g, $3.66 \mathrm{mmol})$, and $\mathrm{PdCl}_{2}(\mathrm{dppf})(240 \mathrm{mg}, 0.37 \mathrm{mmol})$ in 1,4-dioxane $(15 \mathrm{~mL})$ was deoxygenated via evacuation followed by back-filling with nitrogen gas. A $2 \mathrm{M}$ aqueous solution of $\mathrm{Na}_{2} \mathrm{CO}_{3}(3.7 \mathrm{~mL}, 7.4 \mathrm{mmol})$ was then added and the reaction mixture stirred for 2 days at $85{ }^{\circ} \mathrm{C}$. The reaction mixture was diluted with $\mathrm{DCM}$ and washed with water. The combined organic layers were dried $\left(\mathrm{Na}_{2} \mathrm{SO}_{4}\right)$, filtered and concentrated to dryness. The residue was purified by chromatography on $\mathrm{SiO}_{2}$ (2\% to $20 \% \mathrm{MeOH} / \mathrm{DCM}$ gradient) to afford 5 -(9-ethyl-8-(2methylpyrimidin-5-yl)-9H-purin-6-yl)-3-methylindolin-2-one (1.29 g, 91\%). MS (EI) calc'd for $\mathrm{C}_{21} \mathrm{H}_{20} \mathrm{~N}_{7} \mathrm{O}$ [M+H] $]^{+}, 386$; found, 386 .

Steps 2-3: A solution of 5-(9-ethyl-8-(2-methylpyrimidin-5-yl)-9H-purin-6-yl)-3-methylindolin-2-one (100 mg, $0.259 \mathrm{mmol})$ in DMF (2 mL) was treated with $\mathrm{Cs}_{2} \mathrm{CO}_{3}(250 \mathrm{mg}, 0.767 \mathrm{mmol}), 3-$ methoxy-3-methylazetidine, $\mathrm{HCl}$ salt $(80 \mathrm{mg}, 0.58 \mathrm{mmol})$ and $\mathrm{NBS}(50 \mathrm{mg}, 0.28 \mathrm{mmol})$. The suspension was stirred for $30 \mathrm{~min}$, filtered and the filtrate purified by reverse phase chromatography (MeCN/water gradient with $0.1 \%$ TFA modifier). MS (EI) calc'd for $\mathrm{C}_{26} \mathrm{H}_{29} \mathrm{~N}_{8} \mathrm{O}_{2}[\mathrm{M}+\mathrm{H}]^{+}$, 485; found, 485. The racemic material was then dissolved in $\mathrm{MeOH} / \mathrm{MeCN}$ and resolved using chiral column chromatography [Column: Chiralpak AD-H, 21×250 mm; $220 \mathrm{~nm}$ detection; $70 \mathrm{~mL} / \mathrm{min}$ flow rate; $25 \% \mathrm{MeOH}$ and $0.25 \% \mathrm{Me}_{2} \mathrm{NEt}_{\text {in }} \mathrm{CO}_{2}$ ]. The faster eluting enantiomer and more potent isomer came at a retention time of $3.95 \mathrm{~min}(3 \mathrm{e})$; while the slower eluting enantiomer and less active isomer came at a retention time of $4.87 \mathrm{~min}$. Characterization data for $3 \mathrm{e}:{ }^{1} \mathrm{H}$ NMR $\left(600 \mathrm{MHz}, \mathrm{DMSO}-d_{6}\right) \delta 10.70(\mathrm{~s}, 1 \mathrm{H}), 9.21(\mathrm{~s}, 2 \mathrm{H}), 8.95(\mathrm{~s}, 1 \mathrm{H}), 8.88(\mathrm{dd}, \mathrm{J}=8.2,1.8 \mathrm{~Hz}, 1$ $\mathrm{H}), 8.69(\mathrm{~d}, J=1.2 \mathrm{~Hz}, 1 \mathrm{H}), 7.02(\mathrm{~d}, J=8.2 \mathrm{~Hz}, 1 \mathrm{H}), 4.41(\mathrm{q}, J=7.3 \mathrm{~Hz}, 2 \mathrm{H}), 3.66(\mathrm{~d}, J=6.7 \mathrm{~Hz}, 1 \mathrm{H}), 3.01-2.97(\mathrm{~m}, 6 \mathrm{H}), 2.75(\mathrm{~s}, 3 \mathrm{H}), 1.35(\mathrm{t}, J=7.0 \mathrm{~Hz}$, $3 \mathrm{H}), 1.31$ (s, $3 \mathrm{H}), 1.29$ (s, $3 \mathrm{H}) ;{ }^{13} \mathrm{C}$ NMR $(150 \mathrm{MHz}$, DMSO-d $)$ ) $179.7,169.4,157.4(2 \mathrm{C}), 154.0,153.1,152.5,150.1,145.0,131.8,131.7,130.2,129.6$, $125.1,121.9,110.3,72.1,63.4,58.8,57.6,50.4,39.3,26.3,22.1,20.1,15.3 ;$ HRMS (El) calc'd for $\mathrm{C}_{26} \mathrm{H}_{29} \mathrm{~N}_{8} \mathrm{O}_{2}[\mathrm{M}+\mathrm{H}]^{+}, 485.2413 ;$ found, 485.2418 . 

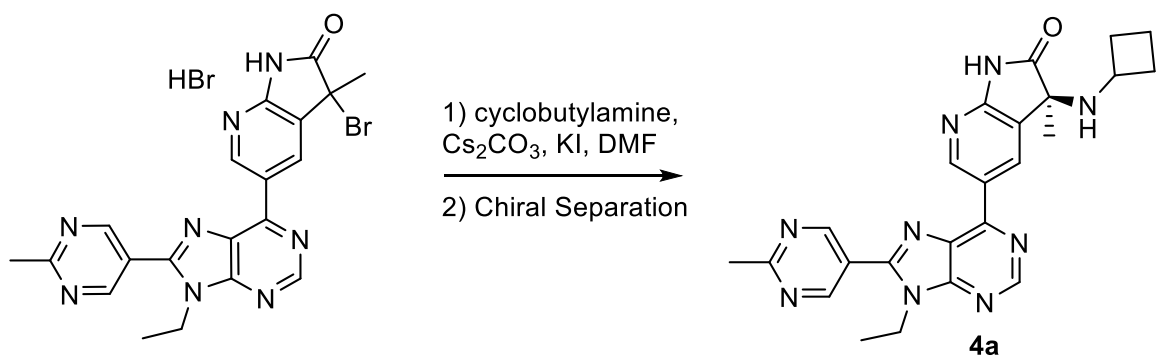

Compound 4a was prepared via the method described for the synthesis of 4c, substituting (S)-tetrahydrofuran-3-amine for cyclobutyl amine. The racemic material was then resolved using chiral column chromatography [Column: Chiralpak IA; $20 \times 250 \mathrm{~mm}$; $20 \mathrm{~mL} / \mathrm{min}$ flow rate; $15 \%$ $\mathrm{EtOH} /$ hexane]. The faster eluting and more active enantiomer (4a) was collected at $25 \mathrm{~min}$, while the slower eluting and less active enantiomer came at a retention time of $32 \mathrm{~min}$. Data for $4 \mathrm{a}:{ }^{1} \mathrm{H}$ NMR $\left(400 \mathrm{MHz}, \mathrm{CD}_{3} \mathrm{OD}\right) \delta 9.70(\mathrm{~s}, 1 \mathrm{H}), 9.27(\mathrm{~s}, 2 \mathrm{H}), 9.08(\mathrm{~d}, \mathrm{~J}=2 \mathrm{~Hz}, 1 \mathrm{H}), 8.99(\mathrm{~s}, 1 \mathrm{H}), 4.55(\mathrm{q}, \mathrm{J}=7.2$ $\mathrm{Hz}, 2 \mathrm{H}), 2.95(\mathrm{~m}, 1 \mathrm{H}), 2.82(\mathrm{~m}, 3 \mathrm{H}), 2.01-2.08(\mathrm{~m}, 1 \mathrm{H}), 1.82-1.89(\mathrm{~m}, 1 \mathrm{H}), 1.70-1.80(\mathrm{~m}, 2 \mathrm{H}), 1.50(\mathrm{~m}, 4 \mathrm{H}), 1.45(\mathrm{~m}, 1 \mathrm{H}), 1.30(\mathrm{~m}, 3 \mathrm{H})$; HRMS $(\mathrm{EI})$ calc'd for $\mathrm{C}_{24} \mathrm{H}_{26} \mathrm{~N}_{9} \mathrm{O}[\mathrm{M}+\mathrm{H}]^{+}, 456.2260$; found, 456.2267 .

(3S)-3-Methyl-5-[9-methyl-8-(2-methylpyrimidin-5-yl)purin-6-yl]-3-[[(3S)-tetrahydrofuran-3-yl]amino]-1H-pyrrolo[2,3-b]pyridin-2-one (4b L006025197).
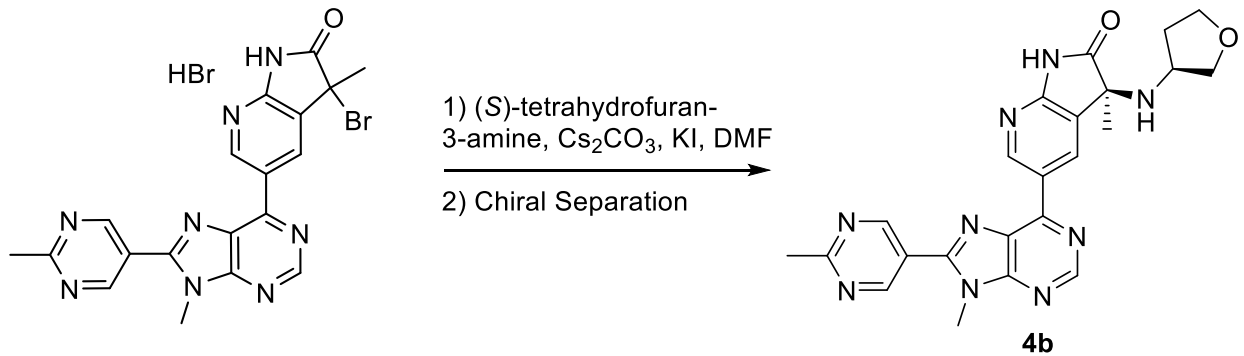

Compound $\mathbf{4 b}$ was prepared from 3-bromo-3-methyl-5-(9-methyl-8-(2-methylpyrimidin-5-yl)-9H-purin-6-yl)-1H-pyrrolo[2,3-b]pyridin-2(3H)-one hydrobromide via the method described for the synthesis of $4 \mathrm{c}$. The racemic material was then resolved using chiral column chromatography [Column: Chiralpak IA; 20x250 mm; $20 \mathrm{~mL} / \mathrm{min}$ flow rate; $70 \% \mathrm{MeOH} / \mathrm{DCM}$ ]. The faster eluting and more active enantiomer (4a) was collected at $6.6 \mathrm{~min}$, while the slower eluting and less active enantiomer came at a retention time of $8.9 \mathrm{~min} .{ }^{1} \mathrm{H} \mathrm{NMR}\left(300 \mathrm{MHz}, \mathrm{DMSO}-d_{6}\right) \delta 11.40(\mathrm{br}, 1 \mathrm{H}), 9.73$ $(\mathrm{s}, 1 \mathrm{H}), 9.33(\mathrm{~s}, 2 \mathrm{H}), 9.03(\mathrm{~s}, 1 \mathrm{H}), 8.94(\mathrm{~s}, 1 \mathrm{H}), 4.02(\mathrm{~s}, 3 \mathrm{H}), 3.67(\mathrm{~m}, 2 \mathrm{H}), 3.45(\mathrm{~m}, 1 \mathrm{H}), 3.05(\mathrm{~m}, 1 \mathrm{H}), 2.79(\mathrm{~s}, 3 \mathrm{H}), 1.40-1.75(\mathrm{~m}, 6 \mathrm{H}) ;{ }^{13} \mathrm{C} \mathrm{NMR}(125$ $\mathrm{MHz}$, DMSO- $\left.d_{6}\right) \delta 181.6,169.4,158.7,157.5(2 \mathrm{C}), 154.4,152.6,151.3,150.4,150.2,131.7,130.2,128.0,126.5,121.6,73.2,66.7,63.2,55.2,40.9$, 34.5, 26.3; 25.2; HRMS (EI) calc'd for $\mathrm{C}_{23} \mathrm{H}_{24} \mathrm{~N}_{9} \mathrm{O}_{2}[\mathrm{M}+\mathrm{H}]^{+}, 458.2053$; found, 458.2065 .

(3S)-5-[9-Ethyl-8-(2-methylpyrimidin-5-yl)purin-6-yl]-3-methyl-3-[[(3S)-tetrahydrofuran-3-yl]amino]-1H-pyrrolo[2,3-b]pyridin-2-one (4c L005573291).
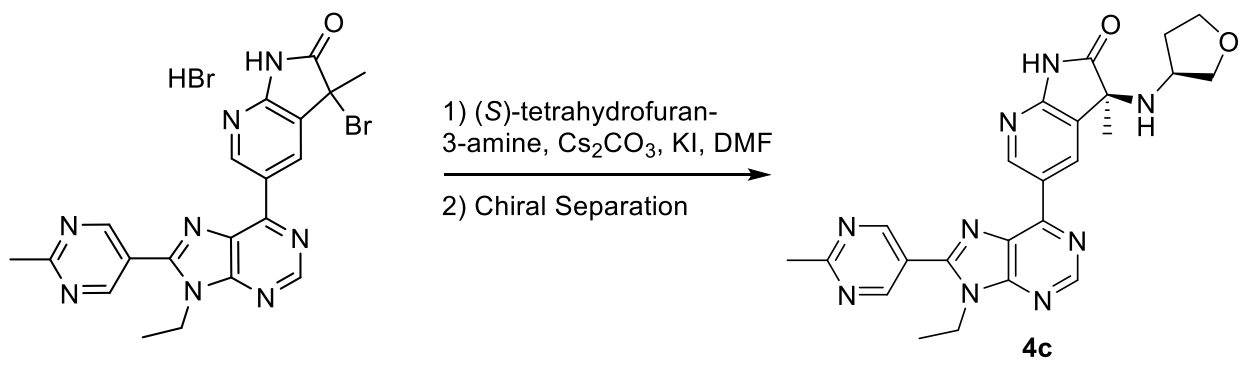

Steps 1-2: A solution of 3-bromo-5-(9-ethyl-8-(2-methylpyrimidin-5-yl)-9H-purin-6-yl)-3-methyl-1H-pyrrolo[2,3-b]pyridin-2(3H)-one hydrobromide salt $(0.55 \mathrm{~g}, 1.0 \mathrm{mmol}$; prepared as described for the synthesis of $4 \mathrm{~d})$ in $5 \mathrm{~mL}$ of DMF was treated with $\mathrm{KI}(84 \mathrm{mg}, 0.50 \mathrm{mmol})$, cesium carbonate $(1.64 \mathrm{~g}, 5.03 \mathrm{mmol})$ and $(\mathrm{S})$-tetrahydrofuran-3-amine $(175 \mathrm{mg}, 2.01 \mathrm{mmol})$. The resulting mixture was stirred for $2 \mathrm{~h}$ at room temperature. The reaction mixture was filtered and the filter cake was washed with DMF $(10 \mathrm{~mL})$. The filtrate was concentrated under reduced pressure and the residue purified by reverse phase chromatography [Column: XBridge BEH130; 19x150 mm, $254 \mathrm{~nm}$ detection; $20 \mathrm{~mL} / \mathrm{min}$ flow rate; $15 \%$ to $26 \%$ $\mathrm{MeCN} /$ water with $\mathrm{NH}_{4} \mathrm{HCO}_{3}$ modifier] to afford 5-(9-ethyl-8-(2-methylpyrimidin-5-yl)-9H-purin-6-yl)-3-methyl-3-(((S)-tetrahydrofuran-3-yl)amino)$1 \mathrm{H}$-pyrrolo[2,3-b]pyridin-2(3H)-one as a mixture of two diastereomers. The diastereomeric mixture was separated using chiral column chromatography [Column: Repaired IA; 21x150 mm, 254/220 nm detection; $25 \mathrm{~mL} / \mathrm{min}$ flow rate; MeOH with 0.1\% diethylamine modifier]. The faster eluting and more active enantiomer came at a retention time of $9.31 \mathrm{~min}(\mathbf{4 c})$, while the slower eluting enantiomer came at a retention time 
of $20.25 \mathrm{~min}$ and was discarded. Characterization data for $4 \mathrm{c}$ : $[\alpha]_{\mathrm{D}}-30^{\circ}(c=2.5 \mathrm{mg} / \mathrm{mL}, \mathrm{MeOH}) ;{ }^{1} \mathrm{H} \mathrm{NMR}\left(600 \mathrm{MHz}, \mathrm{DMSO}-d_{6}\right) \delta 11.42(\mathrm{~s}, 1 \mathrm{H}), 9.69$ (d, J = $1.8 \mathrm{~Hz}, 1 \mathrm{H}), 9.26(\mathrm{~s}, 2 \mathrm{H}), 9.03(\mathrm{~s}, 1 \mathrm{H}), 8.91(\mathrm{~d}, J=1.8 \mathrm{~Hz}, 1 \mathrm{H}), 4.47(\mathrm{q}, J=7.2 \mathrm{~Hz}, 2 \mathrm{H}), 3.66-3.58(\mathrm{~m}, 2 \mathrm{H}), 3.45(\mathrm{q}, J=7.4 \mathrm{~Hz}, 1 \mathrm{H}), 3.31(\mathrm{~m}, 1$ H), $3.22(\mathrm{~d}, J=5.3 \mathrm{~Hz}, 1 \mathrm{H}), 3.01(\mathrm{dt}, J=12.3,6.1 \mathrm{~Hz}, 1 \mathrm{H}), 2.79(\mathrm{~s}, 3 \mathrm{H}), 1.56(\mathrm{~m}, 1 \mathrm{H}), 1.47-1.38(\mathrm{~m}, 7 \mathrm{H}) ;{ }^{13} \mathrm{C} \mathrm{NMR}\left(150 \mathrm{MHz}, \mathrm{DMSO}-d_{6}\right) \delta 181.6$, $169.5,158.7,157.4$ (2C), 153.9, 152.6, 151.5, 150.6, 150.4, 131.6, 130.2, 128.0, 126.4, 121.7, 73.2, 66.7, 63.2, 55.1, 39.4, 34.6, 26.3, 25.1, 15.2. HRMS (EI) calc'd for $\mathrm{C}_{24} \mathrm{H}_{26} \mathrm{~N}_{9} \mathrm{O}_{2}[\mathrm{M}+\mathrm{H}]^{+}, 472.2209$; found, 472.2210 .

(3S)-5-[9-Ethyl-8-(2-methylpyrimidin-5-yl)purin-6-yl]-3-[(2-fluoro-2-methyl-propyl)amino]-3-methyl-1H-pyrrolo[2,3-b]pyridin-2-one (4d L006021422)
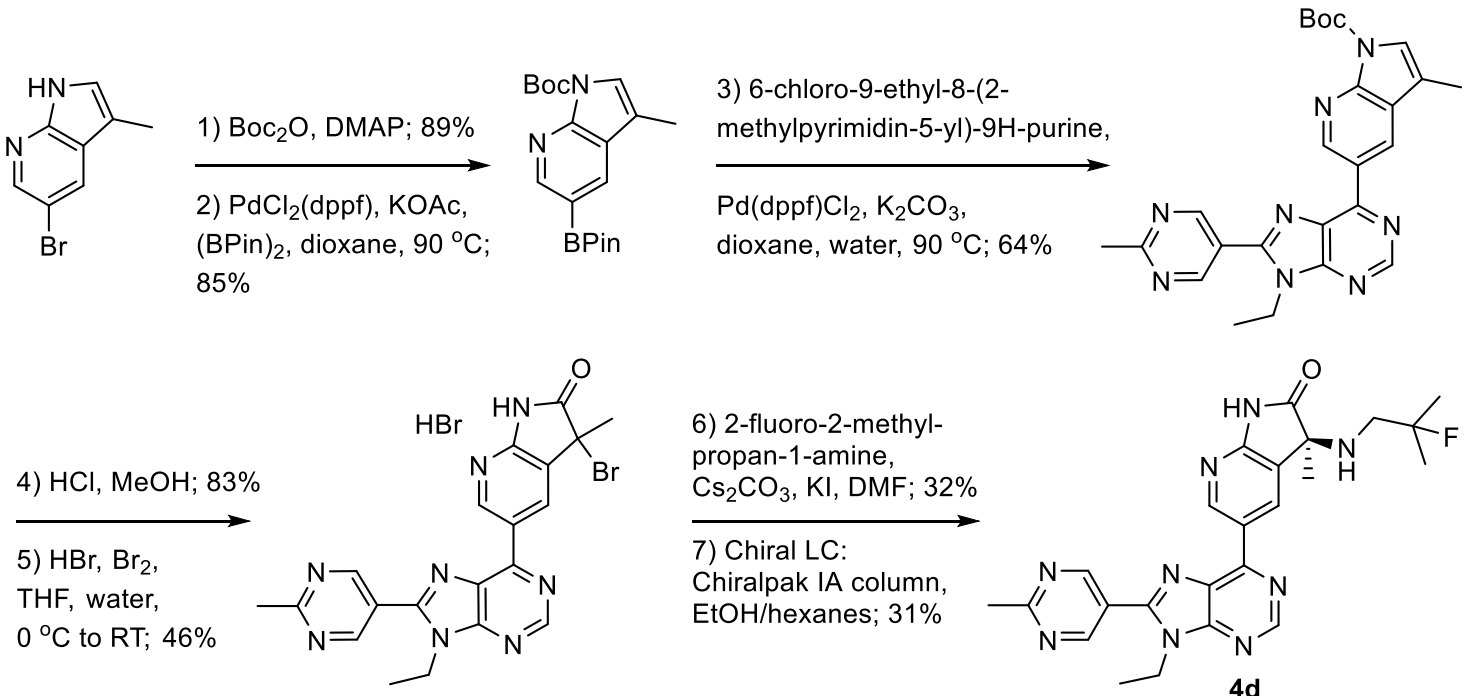

6) 2-fluoro-2-methylpropan-1-amine, $\mathrm{Cs}_{2} \mathrm{CO}_{3}, \mathrm{KI}, \mathrm{DMF} ; 32 \%$

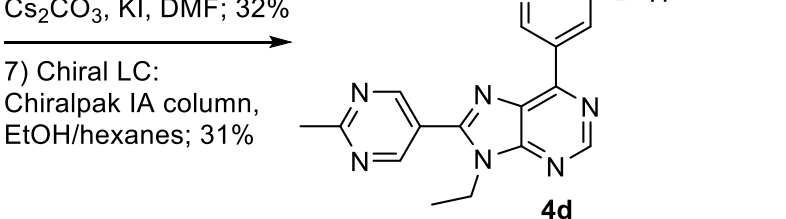

Step 1: To a solution of 5-bromo-3-methyl-1H-pyrrolo[2,3-b]pyridine $(1.50 \mathrm{~g}, 7.11 \mathrm{mmol})$ in $5 \mathrm{~mL}$ of DCM were added DMAP (0.080 g, $0.71 \mathrm{mmol})$ and di-tert-butyl dicarbonate $(1.55 \mathrm{~g}, 7.11 \mathrm{mmol})$. The resulting solution was stirred for $1 \mathrm{~h}$ at room temperature and then concentrated under reduced pressure to afford tert-butyl 5-bromo-3-methyl-1H-pyrrolo[2,3-b]pyridine-1-carboxylate as a white solid (2.0 g, $89 \%)$ which was used in the subsequent step without further purification. MS (EI) calc'd for $\mathrm{C}_{13} \mathrm{H}_{16} \mathrm{BrN}_{2} \mathrm{O}_{2}[\mathrm{M}+\mathrm{H}]^{+}, 311$; found, 311 .

Step 2: To a solution of tert-butyl 5-bromo-3-methyl-1H-pyrrolo[2,3-b]pyridine-1-carboxylate $(2.0 \mathrm{~g}, 6.4 \mathrm{mmol})$ in $20 \mathrm{~mL}$ of dioxane were added $\operatorname{KOAC}(1.26 \mathrm{~g}, 12.9 \mathrm{mmol}),[\mathrm{PinB}]_{2}(1.63 \mathrm{~g}, 6.43 \mathrm{mmol})$ and $\mathrm{PdCl}_{2}(\mathrm{dppf})-\mathrm{CH}_{2} \mathrm{Cl}_{2}(0.53 \mathrm{~g}, 0.64 \mathrm{mmol})$. The resulting mixture was stirred for $1 \mathrm{~h}$ at $90{ }^{\circ} \mathrm{C}$. After cooling to room temperature, the reaction mixture was diluted with water $(10 \mathrm{~mL})$. The resulting solution was extracted with EtOAc $(2 \times 10$ $\mathrm{mL}$ ), then the combined organic layers was concentrated under reduced pressure. The residue was purified by chromatography on $\mathrm{SiO}_{2}$ ( 0 to $20 \%$ EtOAc/hexane) to afford tert-butyl 3-methyl-5-(4,4,5,5-tetramethyl-1,3,2-dioxaborolan-2-yl)-1H-pyrrolo[2,3-b]pyridine-1-carboxylate (2.0 g). MS (EI) calc'd for $\mathrm{C}_{19} \mathrm{H}_{28} \mathrm{BN}_{2} \mathrm{O}_{4}[\mathrm{M}+\mathrm{H}]^{+}, 359$; found, 359.

Step 3: To a solution of tert-butyl-3-methyl-5-(4,4,5,5-tetramethyl-1,3,2-dioxaborolan-2-yl)-1H-pyrrolo[2,3-b]pyridine-1-carboxylate (2.00 g, 5.58 $\mathrm{mmol}$ ) in $16 \mathrm{~mL}$ of dioxane and $4 \mathrm{~mL}$ of water were added 6-chloro-9-ethyl-8-(2-methylpyrimidin-5-yl)-9H-purine (1.53 g, $5.58 \mathrm{mmol})$, potassium carbonate $(1.54 \mathrm{~g}, 11.1 \mathrm{mmol})$ and $\mathrm{PdCl}_{2}(\mathrm{dppf})-\mathrm{CH}_{2} \mathrm{Cl}_{2}(460 \mathrm{mg}, 0.56 \mathrm{mmol})$. The resulting mixture was stirred for $1 \mathrm{~h}$ at $90{ }^{\circ} \mathrm{C}$. After cooling to room temperature, the reaction mixture was diluted with water $(10 \mathrm{~mL})$ and extracted with ethyl acetate $(2 \times 20 \mathrm{~mL})$. The combined organic layers was washed with brine $(5 \mathrm{~mL})$, dried over $\mathrm{Na}_{2} \mathrm{SO}_{4}$ and filtered. The filtrate was concentrated under reduced pressure and the residue purified by chromatography on $\mathrm{SiO}_{2}$ (0\% to 30\% EtOAc/hexane) to afford tert-butyl 3-methyl-5-(9-methyl-8-(2-methylpyrimidin-5-yl)-9H-purin-6-yl)-1Hpyrrolo[2,3-b]pyridine-1-carboxylate (1.71 g, 64\%). MS (EI) calc'd for $\mathrm{C}_{25} \mathrm{H}_{27} \mathrm{~N}_{8} \mathrm{O}_{2}[\mathrm{M}+\mathrm{H}]^{+}, 471$; found, 471.

Step 4: Hydrogen chloride gas was bubbled through a solution of tert-butyl 5-(9-ethyl-8-(2-methylpyrimidin-5-yl)-9H-purin-6-yl)-3-methyl-1Hpyrrolo[2,3-b]pyridine-1-carboxylate $(0.29 \mathrm{~g}, 0.62 \mathrm{mmol})$ in $15 \mathrm{~mL}$ of $\mathrm{MeOH}$. The resulting solution was stirred for $4 \mathrm{~h}$ at room temperature. The reaction mixture was neutralized with triethylamine $(2 \mathrm{~mL})$ and then concentrated under reduced pressure. The residue was purified by chromatography on $\mathrm{SiO}_{2}$ (0\% to $10 \% \mathrm{MeOH} / \mathrm{DCM}$ ) to afford 9-ethyl-6-(3-methyl-1H-pyrrolo[2,3-b]pyridin-5-yl)-8-(2-methylpyrimidin-5-yl)-9Hpurine (200 mg, 83\%). MS (EI) calc'd for $\mathrm{C}_{20} \mathrm{H}_{19} \mathrm{~N}_{8}[\mathrm{M}+\mathrm{H}]^{+}, 371$; found, 371.

Step 5: To a solution of 9-ethyl-6-(3-methyl-1H-pyrrolo[2,3-b]pyridin-5-yl)-8-(2-methylpyrimidin-5-yl)-9H-purine (0.30 g, $0.81 \mathrm{mmol})$ in $4 \mathrm{~mL}$ of THF/water were added at $0{ }^{\circ} \mathrm{C} 48 \%$ aqueous hydrogen bromide $(68 \mathrm{mg}, 0.34 \mathrm{mmol})$ and bromine $(0.090 \mathrm{~mL}, 1.7 \mathrm{mmol})$. The resulting mixture was stirred for $2 \mathrm{~h}$ at room temperature, then filtered. The solid residue was collected to afford 3-bromo-3-ethyl-5-(9-methyl-8-(2-methylpyrimidin-5yl)-9H-purin-6-yl)-1H- pyrrolo[2,3-b]pyridin-2(3H)-one hydrobromide salt (290 mg, 46\%). MS (El) calc'd for $\mathrm{C}_{20} \mathrm{H}_{18} \mathrm{BrN}_{8} \mathrm{O}[\mathrm{M}+\mathrm{H}]^{+}, 465 ;$ found, 465 .

Steps 6-7: A solution of intermediate 3-bromo-5-(9-ethyl-8-(2-methylpyrimidin-5-yl)-9H-purin-6-yl)-3-methyl-1,3-dihydro-2H-pyrrolo[2,3-b]pyridin2-one $\mathrm{HBr}$ salt (180 mg, $0.330 \mathrm{mmol}$ ) in $1 \mathrm{~mL}$ of DMF was treated with $\mathrm{KI}(5.5 \mathrm{mg}, 0.033 \mathrm{mmol})$, 2-fluoro-2-methylpropan-1-amine hydrochloride (50 mg, $0.40 \mathrm{mmol}$ ), and $\mathrm{Cs}_{2} \mathrm{CO}_{3}(540 \mathrm{mg}, 1.65 \mathrm{mmol})$. The reaction mixture was stirred for $2 \mathrm{~h}$ and filtered. The filtrate was concentrated and the residue purified by reverse phase chromatography ( $25 \%$ to $31 \% \mathrm{MeCN} /$ water with $10 \mathrm{mM} \mathrm{NH}_{4} \mathrm{CO}_{3}$ ) to provide the racemic product ( 50 mg, $32 \%$ ). 
The racemic material was then resolved using chiral column chromatography [Column: Chiralpak IA; $20 \times 250 \mathrm{~mm} ; 15 \mathrm{~mL} / \mathrm{min}$ flow rate; $50 \%$ $\mathrm{EtOH} /$ hexanes with $0.1 \% \mathrm{Me}_{2} \mathrm{NH}$ ]. The desired faster eluting enantiomer (compound $\mathbf{4 d}, 15 \mathrm{mg}, 31 \%$ ) came at a retention time of 18.8 min; while the undesired slower eluting enantiomer came at a retention time of $27.8 \mathrm{~min}$. Characterization data for $4 \mathrm{~d}$ : $[\alpha]_{\mathrm{D}}-34^{\circ}(c=2.5 \mathrm{mg} / \mathrm{mL}, \mathrm{MeOH}) ;{ }^{1} \mathrm{H}$ NMR $\left(500 \mathrm{MHz}\right.$, DMSO- $\left.d_{6}\right) \delta 11.40(\mathrm{~s}, 1 \mathrm{H}), 9.66(\mathrm{~d}, J=1.8 \mathrm{~Hz}, 1 \mathrm{H}), 9.24(\mathrm{~s}, 2 \mathrm{H}), 9.02(\mathrm{~s}, 1 \mathrm{H}), 8.91(\mathrm{~d}, J=1.8 \mathrm{~Hz}, 1 \mathrm{H}), 4.46(\mathrm{q}, J=7.1 \mathrm{~Hz}, 2 \mathrm{H}), 2.86$

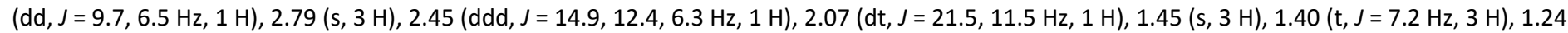
(m, $6 \mathrm{H}) ;{ }^{13} \mathrm{C}$ NMR $\left(125 \mathrm{MHz}\right.$, DMSO-d $\left.d_{6}\right) \delta 181.0,169.5,159.1,157.4(2 \mathrm{C}), 153.9,152.6,151.5,150.6,150.3,131.5,130.2,127.0,126.5,121.7,96.5$, $63.2,52.9,52.7,26.3,25.4$ (d), 24.9 (d), 24.6, 15.2; HRMS (EI) calc'd for $\mathrm{C}_{24} \mathrm{H}_{27} \mathrm{FN}_{9} \mathrm{O}[\mathrm{M}+\mathrm{H}]^{+}, 476.2322 ;$ found, 476.2325.

\section{(3S)-5-[9-Ethyl-8-(2-methylpyrimidin-5-yl)purin-6-yl]-3-(3-methoxy-3-methyl-azetidin-1-yl)-3-methyl-1H-pyrrolo[2,3-b]pyridin-2-one (4e L-} 005567543).
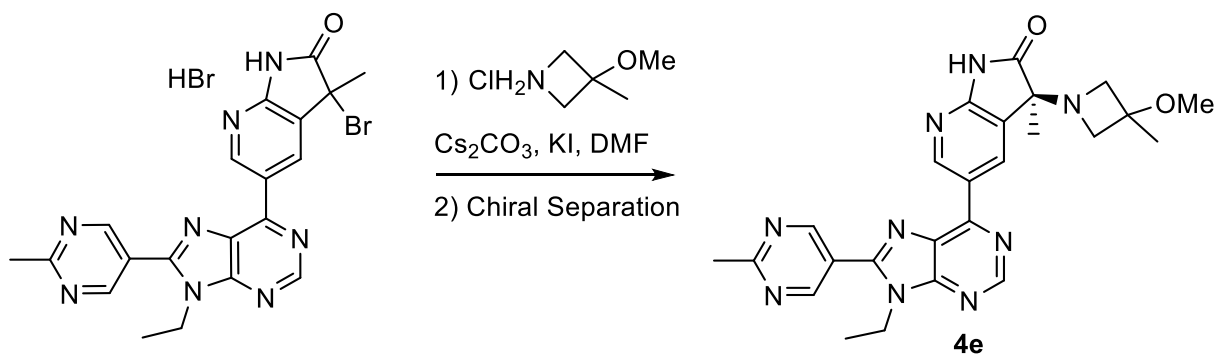

Compound 4e was prepared via the route outlined for the synthesis of compound 4c, substituting (S)-tetrahydrofuran-3-amine for 3-methoxy-3methylazetidine hydrochloride. The racemic mixture was separated using chiral column chromatography [Column: Repaired IA; 21x150 mm, 254/220 nm detection; $25 \mathrm{~mL} / \mathrm{min}$ flow rate; $50 \%$ IPA in hexanes]. The faster eluting and more active enantiomer came at a retention time of 6.6

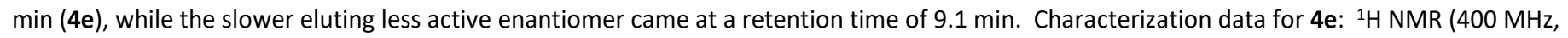
$\left.\mathrm{CD}_{3} \mathrm{OD}\right) \delta 9.73(\mathrm{~s}, 1 \mathrm{H}), 9.26(\mathrm{~s}, 2 \mathrm{H}), 9.08(\mathrm{~s}, 1 \mathrm{H}), 9.00(\mathrm{~s}, 1 \mathrm{H}), 4.55(\mathrm{q}, J=7.2 \mathrm{~Hz}, 2 \mathrm{H}), 3.81(\mathrm{~m}, 1 \mathrm{H}), 3.40(\mathrm{~m}, 2 \mathrm{H}), 3.20(\mathrm{~m}, 1 \mathrm{H}), 3.13(\mathrm{~s}, 3 \mathrm{H}), 2.85$ $(\mathrm{s}, 3 \mathrm{H}), 1.51(\mathrm{~m}, 6 \mathrm{H}), 1.43(\mathrm{~s}, 3 \mathrm{H})$; HRMS (EI) calc'd for $\mathrm{C}_{25} \mathrm{H}_{28} \mathrm{~N}_{9} \mathrm{O}_{2}[\mathrm{M}+\mathrm{H}]^{+}$, 486.2366; found, 486.2372.

(3S)-5-[9-Ethyl-8-(2-methylpyrimidin-5-yl)purin-6-yl]-1'-isopropyl-spiro[indoline-3,2'-pyrrolidine]-2-one (5a L-005472767).<smiles>O=C(O)CCc1c[nH]c2ccccc12</smiles>

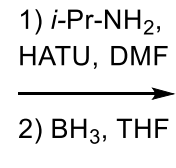<smiles>CC(C)NCCCc1c[nH]c2ccccc12</smiles>

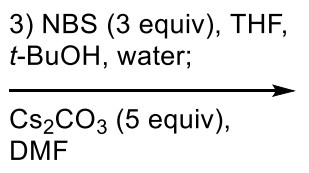<smiles>CC(C)N1CCCC12C(=O)Nc1ccc(Br)cc12</smiles><smiles>CC(C)N1CCCC12C(=O)N(C(=O)OCc1ccccc1)c1ccc(Br)cc12</smiles>

5) $\mathrm{PdCl}_{2}(\mathrm{dppf}), \mathrm{KOAc}$, (BPin) 2 , dioxane, $80^{\circ} \mathrm{C}$

add $\mathrm{K}_{3} \mathrm{PO}_{4}, 6$-chloro-9-ethyl8-(2-methyl-pyrimidin-5-yl)$9 \mathrm{H}$-purine, water, $80^{\circ} \mathrm{C}$<smiles>CCn1c(-c2cnc(C)nc2)nc2c(-c3ccc4c(c3)C3(CCCN3C(C)C)C(=O)N4C(=O)OC(C)(C)C)ncnc21</smiles>

\section{6) TFA, DCM}

7) Chiral separation<smiles>CCn1c(-c2cnc(C)nc2)nc2c(-c3ccc4c(c3)C3(CCCN3C(C)C)C(=O)N4)ncnc21</smiles>

Steps 1-2: A solution of 3-(1H-indol-3-yl)propanoic acid $(500 \mathrm{mg}, 2.64 \mathrm{mmol})$ in DMF $(10 \mathrm{~mL})$ was treated with isopropylamine $(0.300 \mathrm{~mL}$, 3.50 $\mathrm{mmol})$ and HATU $(1.20 \mathrm{~g}, 3.16 \mathrm{mmol})$. The reaction mixture was stirred for 3 hours, then concentrated to dryness. The residue was then taken-up into EtOAc and washed with $1 \mathrm{~N} \mathrm{HCl}$ and sat'd $\mathrm{NaHCO}_{3}$, the organic layer was dried $\left(\mathrm{Na}_{2} \mathrm{SO}_{4}\right)$ and concentrated to dryness. The residue was dissolved in THF $(10 \mathrm{~mL})$ and treated with a $1 \mathrm{M}$ THF solution of borane-THF complex $(4.0 \mathrm{~mL}, 4.0 \mathrm{mmol})$ and stirred overnight at $70{ }^{\circ} \mathrm{C}$. Once cool, the reaction was quenched dropwise with methanol and concentrated. The residue was purified by chromatography on $\mathrm{SiO}_{2}(0-50 \% \mathrm{MeOH} / \mathrm{DCM})$ to provide the desired amine (400 mg, 70\%). MS (EI) calc'd for $\mathrm{C}_{14} \mathrm{H}_{21} \mathrm{~N}_{2}[\mathrm{M}+\mathrm{H}]^{+}, 217$; found, 217. 
Step 3: A solution of 3-(1H-indol-3-yl)- $\mathrm{N}$-isopropylpropan-1-amine (400 mg, $1.85 \mathrm{mmol})$ in THF (4 mL), tert-butyl alcohol (4 mL) and water (2 mL) was treated with NBS $(1.0 \mathrm{~g}, 5.6 \mathrm{mmol})$ and the reaction mixture stirred for $10 \mathrm{~min}$. The mixture was concentrated to dryness, dissolved into DMF $(5 \mathrm{~mL})$, then treated with cesium carbonate $(3.0 \mathrm{~g}, 9.2 \mathrm{mmol})$ and stirred for $30 \mathrm{~min}$. The suspension was filtered through a pad of Celite and concentrated to dryness. The solid residue was suspended in DCM, filtered and concentrated. The desired product is soluble in DCM. The crude material was purified by reverse phase chromatography (MeCN/water with $0.1 \%$ TFA modifier) to provide the desired spirocycle as a TFA salt ( 377 $\mathrm{mg}, 48 \%)$. MS (EI) calc'd for $\mathrm{C}_{14} \mathrm{H}_{18} \mathrm{BrN}_{2} \mathrm{O}[\mathrm{M}+\mathrm{H}]^{+}, 309$; found, 309.

Step 4: A solution of 5-bromo-1'-isopropylspiro[indoline-3,2'-pyrrolidin]-2-one, TFA salt (110 mg, $0.260 \mathrm{mmol})$ in DCM (1 mL) was treated with DMAP ( $6 \mathrm{mg}, 0.05 \mathrm{mmol}), \mathrm{Boc}_{2} \mathrm{O}(75 \mathrm{mg}, 0.34 \mathrm{mmol})$ and Hunig's base $(0.10 \mathrm{~mL}, 0.57 \mathrm{mmol})$, then stirred for $3 \mathrm{~h}$. The mixture was concentrated to dryness and purified by chromatography on $\mathrm{SiO}_{2}(0-20 \% \mathrm{MeOH} / \mathrm{DCM})$ to provide the desired product (105 mg, $\left.99 \%\right)$. MS (EI) calc'd for $\mathrm{C}_{19} \mathrm{H}_{26} \mathrm{BrN}_{2} \mathrm{O}_{3}[\mathrm{M}+\mathrm{H}]^{+}$, 409; found, 409.

Step 5: A mixture containing tert-butyl 5-bromo-1'-isopropyl-2-oxospiro[indoline-3,2'-pyrrolidine]-1-carboxylate (105 mg, $0.257 \mathrm{mmol}$ ) in dioxane $(1 \mathrm{~mL})$ was treated with $\mathrm{PdCl}_{2}$ (dppf) $(20 \mathrm{mg}, 0.024 \mathrm{mmol}), \mathrm{KOAc}(35 \mathrm{mg}, 0.36 \mathrm{mmol})$ and $(\mathrm{BPin})_{2}(75 \mathrm{mg}, 0.30 \mathrm{mmol})$. The reaction was stirred for 3 hours at $100{ }^{\circ} \mathrm{C}$ and cooled to RT. The mixture was treated with more $\mathrm{PdCl}_{2}$ (dppf) (20 mg, 0.024 mmol), 6-chloro-9-ethyl-8-(2-methyl-pyrimidin-5yl)-9H-purine (60 mg, $0.22 \mathrm{mmol})$ and $1 \mathrm{M}$ aqueous $\mathrm{K}_{3} \mathrm{PO}_{4}(0.60 \mathrm{~mL}, 0.60 \mathrm{mmol})$ and stirred overnight at $80{ }^{\circ} \mathrm{C}$. The mixture was filtered and purified by reverse phase chromatography (MeCN/water with $0.1 \%$ TFA) to provide the desired product ( $35 \mathrm{mg}, 24 \%$ ).

Steps 6-7: A solution of tert-butyl 5-(9-ethyl-8-(2-methylpyrimidin-5-yl)-9H-purin-6-yl)-1'-isopropyl-2-oxospiro[indoline-3,2'-pyrrolidine]-1carboxylate ( $35 \mathrm{mg}, 0.062 \mathrm{mmol}$ ) in $1 \mathrm{~mL}$ of 1:1 TFA/DCM and stirred for $30 \mathrm{~min}$. The residue was concentrated to an oil giving racemic-5a ( $35 \mathrm{mg}$, $100 \%)$. The racemic product was resolved using chiral column chromatography [Column: Chiralpak AS- $\mathrm{H} ; 25 \% \mathrm{MeOH}$ with $0.25 \% \mathrm{Me} 2 \mathrm{NEt}$ and $75 \%$ $\mathrm{CO}_{2}$; Flow rate: $70 \mathrm{~mL} / \mathrm{min}$; Detector $220 \mathrm{~nm}$ ]. The faster-eluting enantiomer (retention time $4.39 \mathrm{~min}$ ) was less active, while the slower-eluting enantiomer (retention time $6.48 \mathrm{~min}$ ) was the more active $(5 \mathrm{a})$. Characterization data for $5 \mathrm{a}$ : ${ }^{1} \mathrm{H} \mathrm{NMR}\left(600 \mathrm{MHz}, \mathrm{DMSO}-d_{6}\right) \delta 10.57(\mathrm{~s}, 1 \mathrm{H}), 9.20(\mathrm{~s}$, $2 \mathrm{H}), 8.95(\mathrm{~s}, 1 \mathrm{H}), 8.80(\mathrm{dd}, J=8.2,1.8 \mathrm{~Hz}, 1 \mathrm{H}), 8.71(\mathrm{~s}, 1 \mathrm{H}), 7.00(\mathrm{~d}, J=8.2 \mathrm{~Hz}, 1 \mathrm{H}), 4.42(\mathrm{q}, J=7.3 \mathrm{~Hz}, 2 \mathrm{H}), 3.25(\mathrm{~m}, 1 \mathrm{H}), 3.16(\mathrm{~m}, 1 \mathrm{H}), 2.75(\mathrm{~s}, 3$ $\mathrm{H}), 2.73(\mathrm{~m}, 1 \mathrm{H}), 2.00-2.10(\mathrm{~m}, 3 \mathrm{H}), 1.91(\mathrm{~m}, 1 \mathrm{H}), 1.35(\mathrm{t}, J=7.0 \mathrm{~Hz}, 3 \mathrm{H}), 0.82(\mathrm{~d}, J=6.5 \mathrm{~Hz}, 3 \mathrm{H}), 0.80(\mathrm{~d}, J=6.5 \mathrm{~Hz}, 3 \mathrm{H}) ;{ }^{13} \mathrm{C} \mathrm{NMR}(125 \mathrm{MHz}$, DMSO- $\left.d_{6}\right) \delta 182.2,169.4,157.4(2 \mathrm{C}), 154.0,153.2,152.5,150.0,144.6,133.7,131.0,130.2,129.4,125.1,121.9,110.3,70.3,49.3,48.7,40.9,26.3$, 23.5, 22.3, 21.2, 20.9, 15.3; HRMS (EI) calc'd for $\mathrm{C}_{26} \mathrm{H}_{29} \mathrm{~N}_{8} \mathrm{O}[\mathrm{M}+\mathrm{H}]^{+}, 469.2464$; found, 469.2474 .

(3S)-1'-(Cyclopropanecarbonyl)-5-[9-methyl-8-(2-methylpyrimidin-5-yl)purin-3-ium-6-yl]spiro[indoline-3,2'-pyrrolidine]-2-one (5b L-005581651) and (3S)-1'-(Cyclopropanecarbonyl)-1-methyl-5-[9-methyl-8-(2-methylpyrimidin-5-yl)purin-6-yl]spiro[indoline-3,2'-pyrrolidine]-2-one (5d L005582321):

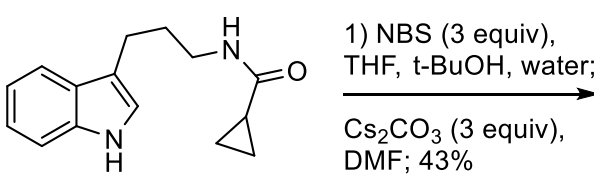
DMF; $43 \%$<smiles>O=C(C1CC1)N1CCCC12C(=O)Nc1ccc(Br)cc12</smiles>

2) $(\mathrm{Boc})_{2} \mathrm{O}, \mathrm{TEA}$, DMAP, DCM; $88 \%$

3) Chiral SFC: Chiralpak IC-3 column, $\mathrm{EtOH} / \mathrm{CO}_{2}$.<smiles>CC(C)(C)OC(=O)N1C(=O)[C@@]2(CCCN2C(=O)C2CC2)c2cc(Br)ccc21</smiles>

Boc<smiles>Cc1ncc(-c2nc3c(-c4ccc5c(c4)[C@]4(CCCN4C(=O)C4CC4)N(C(=O)OC(C)(C)C)C(=O)[C@]54CCCN4)ncnc3n2C)cn1</smiles>
$79 \%$ two steps

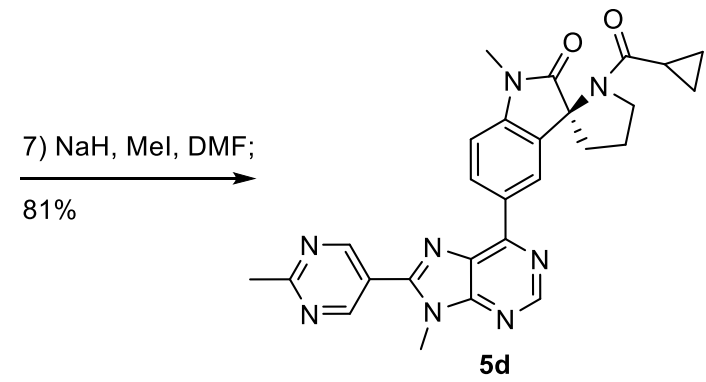

Step 1: A mixture N-(3-(1H-indol-3-yl)propyl)cyclopropanecarboxamide (5.50 g, $22.7 \mathrm{mmol})$ in THF (30 mL), t-BuOH (30 mL) and water (10 mL), was treated portionwise with NBS $(12.1 \mathrm{~g}, 68.1 \mathrm{mmol})$. The mixture was stirred for $5 \mathrm{~h}$, then concentrated under vacuum. The residue was then 
dissolved in DMF $(80 \mathrm{~mL})$, treated with $\mathrm{Cs}_{2} \mathrm{CO}_{3}(22.2 \mathrm{~g}, 68.1 \mathrm{mmol})$ and stirred for $30 \mathrm{~min}$. The reaction mixture was quenched with water (100 $\left.\mathrm{mL}\right)$ and extracted with DCM $(3 \times 150 \mathrm{~mL})$. The combined organic layers were washed with brine $(5 \times 150 \mathrm{~mL}), \mathrm{dried}\left(\mathrm{Na}_{2} \mathrm{SO}_{4}\right)$, filtered and concentrated. The residue was purified by chromatography on $\mathrm{SiO}_{2}$ (25\% EtOAc/petroleum ether) providing 5-bromo-1'-(cyclopropanecarbonyl)spiro[indoline3,2'-pyrrolidin]-2-one (3.3 g, 43\%). ${ }^{1} \mathrm{H}$ NMR (400 MHz, DMSO- $\left.d_{6}\right) \delta 10.40(\mathrm{~s}, 1 \mathrm{H}), 7.40(\mathrm{~s}, 1 \mathrm{H}), 7.32(\mathrm{dd}, J=8.4,2 \mathrm{~Hz}, 1 \mathrm{H}), 6.72(\mathrm{~d}, J=8 \mathrm{~Hz}, 1 \mathrm{H}$ ), 4.08-4.03 (m, $1 \mathrm{H}), 3.88-3.83(\mathrm{~m}, 1 \mathrm{H}), 2.30-2.10(\mathrm{~m}, 3 \mathrm{H}), 1.98-1.92(\mathrm{~m}, 1 \mathrm{H}), 1.85-1.79(\mathrm{~m}, 1 \mathrm{H}), 0.77-0.65$ (m, $2 \mathrm{H}), 0.58$ (m, $2 \mathrm{H}) . \mathrm{MS}(\mathrm{El}) \mathrm{calc}$ 'd for $\mathrm{C}_{15} \mathrm{H}_{16} \mathrm{BrN}_{2} \mathrm{O}_{2}[\mathrm{M}+\mathrm{H}]^{+}, 335$; found, 335, 337.

Step 2: A solution of 5-bromo-1'-(cyclopropanecarbonyl)spiro[indoline-3,2'-pyrrolidin]-2-one (2.1 g, $6.3 \mathrm{mmol}), \mathrm{NEt}_{3}(1.75 \mathrm{~mL}, 12.5 \mathrm{mmol}$ ) and $\operatorname{DMAP}(0.765 \mathrm{~g}, 6.26 \mathrm{mmol})$ in DCM $(50 \mathrm{~mL})$ was treated with di-tert-butyl dicarbonate $(1.64 \mathrm{~g}, 7.52 \mathrm{mmol})$ and stirred for $2 \mathrm{~h}$. The reaction mixture was quenched with water $(100 \mathrm{~mL})$ and extracted with DCM $(2 \times 100 \mathrm{~mL})$. The combined organic layers were washed with brine $(3 \times 100 \mathrm{~mL})$, dried $\left(\mathrm{Na}_{2} \mathrm{SO}_{4}\right)$ and concentrated. The residue was purified by chromatography on $\mathrm{SiO}_{2}(0-15 \% \mathrm{EtOAc} /$ petroleum ether) to afford the product ( $2.4 \mathrm{~g}$, $88 \%)$. MS (El) calc'd for $\mathrm{C}_{20} \mathrm{H}_{24} \mathrm{BrN}_{2} \mathrm{O}_{4}[\mathrm{M}+\mathrm{H}]^{+}, 435$; found, 435.

Step 3: Racemic tert-butyl 5-bromo-1'-(cyclopropanecarbonyl)-2-oxospiro[indoline-3,2'-pyrrolidine]-1-carboxylate was resolved into separate enantiomers using chiral SFC chromatography [Column: Chiralpak IC-3 $3 \mu \mathrm{m} ; 25 \%$ EtOH with 0.05\% isopropylamine and 75\% $\mathrm{CO}_{2}$; Flow rate: 4 $\mathrm{mL} / \mathrm{min}$; Detector $220 \mathrm{~nm}$; Retention time 1: $1.07 \mathrm{~min}$; Retention time 2: $1.42 \mathrm{~min}$ ]. The faster-eluting enantiomer came at a retention time of 1.07 min, and was discarded. The slower-eluting enantiomer came at a retention time of $1.42 \mathrm{~min}$ and was collected.

Steps 4-5: A suspension of (S)-tert-butyl 5-bromo-1'-(cyclopropanecarbonyl)-2-oxospiro[indoline-3,2'-pyrrolidine]-1-carboxylate (2.5 g, 5.8 mmol), G2-XPhos (200 mg, $0.250 \mathrm{mmol}), \mathrm{KOAc}(800 \mathrm{mg}, 8.2 \mathrm{mmol})$ and (BPin) $2(2.0 \mathrm{~g}, 7.9 \mathrm{mmol})$ in $15 \mathrm{~mL}$ of dioxane was deoxygenated by bubbling nitrogen for $10 \mathrm{~min}$. The reaction mixture was warmed to $85^{\circ} \mathrm{C}$ and stirred for $24 \mathrm{~h}$, then filtered and concentrated. The residue was then dissolved in dioxane $(20 \mathrm{~mL})$ and treated with 6-chloro-9-methyl-8-(2-methylpyrimidin-5-yl)-9H-purine $(1.5 \mathrm{~g}, 5.8 \mathrm{mmol}), \mathrm{PdCl}_{2}$ (dtbpf) (180 mg, 0.28 mmol) and $2 \mathrm{M}$ aqueous $\mathrm{K}_{3} \mathrm{PO}_{4}(4.7 \mathrm{~mL}, 9.4 \mathrm{mmol})$. The resulting suspension was deoxygenated by bubbling nitrogen for $10 \mathrm{~min}$ and stirred overnight at $80{ }^{\circ} \mathrm{C}$. The mixture was diluted with $\mathrm{DCM}$ and washed with water. The organic layer was dried $\left(\mathrm{Na}_{2} \mathrm{SO}_{4}\right)$ and concentrated to dryness. Chromatography on $\mathrm{SiO}_{2}$ (7-60\% EtOAc/DCM then 2 to $20 \% \mathrm{MeOH} / \mathrm{DCM}$ ) gave the desired Boc-protected intermediate (4.55 mg, $79 \%$ ). $\mathrm{MS}$ (EI) calc'd for $\mathrm{C}_{31} \mathrm{H}_{33} \mathrm{~N}_{8} \mathrm{O}_{4}[\mathrm{M}+\mathrm{H}]^{+}, 581$; found, 581 .

Step 6: A solution of (S)-tert-butyl 1'-(cyclopropanecarbonyl)-5-(9-methyl-8-(2-methylpyrimidin-5-yl)-9H-purin-6-yl)-2-oxospiro[indoline-3,2'pyrrolidine]-1-carboxylate $(615 \mathrm{mg}, 1.06 \mathrm{mmol})$ in $15 \mathrm{~mL}$ of DCM was treated with a $4 \mathrm{M}$ solution of $\mathrm{HCl}$ in dioxane $(3.0 \mathrm{~mL}, 12 \mathrm{mmol})$ and stirred for $2 \mathrm{~h}$. The mixture was concentrated and dried under vacuum to provide the $\mathrm{HCl}$ salt $(430 \mathrm{mg}, 84 \%)$ of $5 \mathrm{~b}$. ${ }^{1} \mathrm{H} \mathrm{NMR}\left(600 \mathrm{MHz}, \mathrm{DMSO}-d_{6}\right) \delta 10.63$ $(\mathrm{s}, 1 \mathrm{H}), 9.28(\mathrm{~s}, 2 \mathrm{H}), 8.93(\mathrm{~s}, 1 \mathrm{H}), 8.87(\mathrm{~d}, J=8.2 \mathrm{~Hz}, 1 \mathrm{H}), 8.57(\mathrm{~s}, 1 \mathrm{H}), 6.98(\mathrm{~d}, J=8.2 \mathrm{~Hz}, 1 \mathrm{H}), 4.10(\mathrm{~m}, 1 \mathrm{H}), 3.95(\mathrm{~s}, 3 \mathrm{H}), 3.90(\mathrm{q}, J=9.7 \mathrm{~Hz}, 1 \mathrm{H})$, $2.74(\mathrm{~s}, 3 \mathrm{H}), 2.26(\mathrm{~m}, 2 \mathrm{H}), 2.16(\mathrm{~m}, 1 \mathrm{H}), 2.02(\mathrm{~m}, 1 \mathrm{H}), 1.82(\mathrm{~m}, 1 \mathrm{H}), 0.71(\mathrm{~m}, 1 \mathrm{H}), 0.63(\mathrm{~m}, 1 \mathrm{H}), 0.54(\mathrm{~m}, 1 \mathrm{H}), 0.50(\mathrm{~m}, 1 \mathrm{H}) ;{ }^{13} \mathrm{C} \mathrm{NMR}(150 \mathrm{MHz}$ DMSO- $\left.d_{6}\right) \delta 178.4,170.6,169.2,157.4(2 \mathrm{C}), 154.4,153.0,152.4,150.6,145.1,133.4,131.5,130.0,129.3,122.7,121.7,110.0,67.7,48.5,38.1,30.8$, 26.3, 24.5, 12.6, 8.0, 7.7; HRMS (EI) calc'd for $\mathrm{C}_{26} \mathrm{H}_{25} \mathrm{~N}_{8} \mathrm{O}_{2}[\mathrm{M}+\mathrm{H}]^{+}, 481.2100$; found, 481.2109 .

Step 7: A mixture containing (S)-1'-(cyclopropanecarbonyl)-5-(9-methyl-8-(2-methylpyrimidin-5-yl)-9H-purin-6-yl)spiro[indoline-3,2'-pyrrolidin]-2one $5 \mathbf{b}(80 \mathrm{mg}, 0.17 \mathrm{mmol})$ in dioxane $(1 \mathrm{~mL})$ was treated with $60 \%$ sodium hydride $(10 \mathrm{mg}, 0.42 \mathrm{mmol})$, stirred for $10 \mathrm{~min}$, then treated with iodomethane $(70 \mathrm{mg}, 0.49 \mathrm{mmol})$. The reaction mixture was stirred for 4 hours, then concentrated, suspended in DMSO and filtered. Reverse phase chromatography (MeCN/water with $0.1 \% \mathrm{NH}_{4} \mathrm{OH}$ modifier) gave the desired product $5 \mathrm{~d}(81 \%) .[\alpha]_{\mathrm{D}}-55^{\circ}(c=2.5 \mathrm{mg} / \mathrm{mL}, \mathrm{MeOH}) ;{ }^{1} \mathrm{H} \mathrm{NMR}$ $\left(600 \mathrm{MHz}, \mathrm{DMSO}-d_{6}\right) \delta 9.29(\mathrm{~s}, 2 \mathrm{H}), 8.97(\mathrm{dd}, \mathrm{J}=8.2,1.5 \mathrm{~Hz}, 1 \mathrm{H}), 8.94(\mathrm{~s}, 1 \mathrm{H}), 8.62(\mathrm{~s}, 1 \mathrm{H}), 7.18(\mathrm{~d}, J=8.2 \mathrm{~Hz}, 1 \mathrm{H}), 4.12(\mathrm{~m}, 1 \mathrm{H}), 3.96(\mathrm{~s}, 3 \mathrm{H}), 3.92$ $(\mathrm{q}, J=10 \mathrm{~Hz}, 1 \mathrm{H}), 3.14(\mathrm{~s}, 3 \mathrm{H}), 2.74(\mathrm{~s}, 3 \mathrm{H}), 2.29(\mathrm{~m}, 2 \mathrm{H}), 2.17(\mathrm{~m}, 1 \mathrm{H}), 2.04(\mathrm{~m}, 1 \mathrm{H}), 1.82(\mathrm{~m}, 1 \mathrm{H}), 0.71(\mathrm{~m}, 1 \mathrm{H}), 0.63(\mathrm{~m}, 1 \mathrm{H}), 0.54(\mathrm{~m}, 1 \mathrm{H}), 0.49$ $(\mathrm{m}, 1 \mathrm{H}) ;{ }^{13} \mathrm{C}$ NMR $\left(125 \mathrm{MHz}\right.$, DMSO-d $\left.d_{6}\right) \delta 176.7,170.7,169.2,157.4(2 \mathrm{C}), 154.4,152.8,152.4,150.7,146.4,132.6,131.6,130.1,129.9,122.2,121.7$, $108.8,67.3,48.5,37.9,30.8,26.9,26.3,24.6,12.6,8.0,7.7$; HRMS (EI) calc'd for $\mathrm{C}_{27} \mathrm{H}_{27} \mathrm{~N}_{8} \mathrm{O}_{2}[\mathrm{M}+\mathrm{H}]^{+}, 495.2257$; found, 495.2255. 
(3S)-1'-(Cyclopropanecarbonyl)-5-[9-ethyl-8-(2-methylpyrimidin-5-yl)purin-6-yl]spiro[indoline-3,2'-pyrrolidine]-2-one (5c L-005469044) and (3S)1'-(Cyclopropanecarbonyl)-5-[9-ethyl-8-(2-methylpyrimidin-5-yl)purin-6-yl]-1-methyl-spiro[indoline-3,2'-pyrrolidine]-2-one (5e L-005492796).<smiles>NCCCc1c[nH]c2ccccc12</smiles>

3) $(\mathrm{Boc})_{2} \mathrm{O}$, TEA, DMAP, DCM

4) $\mathrm{PdCl}_{2}$ (dppf), $\mathrm{KOAc}$, (BPin) $)_{2}$, dioxane, $80^{\circ} \mathrm{C}$

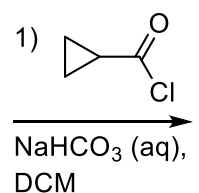<smiles>O=C(NCCCc1c[nH]c2ccccc12)C1CC1</smiles>

2) NBS (3 equiv), $\mathrm{THF}, t-\mathrm{BuOH}$, water; $\mathrm{Cs}_{2} \mathrm{CO}_{3}$ (3 equiv), DMF<smiles>O=C(C1CC1)N1CCCC12C(=O)Nc1ccc(Br)cc12</smiles>

5) $\mathrm{PdCl}_{2}$ (dtbpf), $\mathrm{K}_{3} \mathrm{PO}_{4}$ 6-chloro-9-ethyl-8-(2-methylpyrimidin-5-yl)-9H-purine dioxane, water, $80^{\circ} \mathrm{C}$

6) $\mathrm{HCl}, \mathrm{EtOAc}$

7) Chiral separation<smiles>CCn1c(-c2cnc(C)nc2)nc2c(-c3ccc4c(c3)C3(CCCN3C(=O)C3CC3)C(=O)N4)ncnc21</smiles><smiles>CCn1c(-c2cnc(C)nc2)nc2c(-c3ccc4c(c3)C3(CCCN3C(=O)C3CC3)C(=O)N4C)ncnc21</smiles>

Step 1: A mixture of 3-(1H-indol-3-yl)propan-1-amine $(4.50 \mathrm{~g}, 25.8 \mathrm{mmol})$ in aqueous $\mathrm{Na}_{2} \mathrm{CO}_{3}(4.34 \mathrm{~g}, 51.7 \mathrm{mmol}$, dissolved in $60 \mathrm{~mL}$ of water) and $\mathrm{DCM}(100 \mathrm{~mL})$ was treated dropwise at $0{ }^{\circ} \mathrm{C}$ with cyclopropanecarbonyl chloride $(2.70 \mathrm{~g}, 25.8 \mathrm{mmol})$. The mixture was warmed to room temperature and stirred for $1 \mathrm{~h}$. The reaction mixture was then diluted with $\mathrm{DCM}(300 \mathrm{~mL})$, washed with brine $(3 \times 150 \mathrm{~mL})$, dried over anhydrous $\mathrm{Na}_{2} \mathrm{SO}_{4}$ and filtered. The filtrate was concentrated under reduced pressure and purified by chromatography on $\mathrm{SiO}_{2}(0 \%$ to $20 \% \mathrm{EtOAc} /$ petroleum ether) to provide $\mathrm{N}-\left(3-\left(1 \mathrm{H}\right.\right.$-indol-3-yl)propyl)cyclopropanecarboxamide (5.50 g, 88\%). MS (El) calc'd for $\mathrm{C}_{15} \mathrm{H}_{19} \mathrm{~N}_{2} \mathrm{O}[\mathrm{M}+\mathrm{H}]^{+}, 243 ;$ found, 243.

Step 2: A mixture $\mathrm{N}-(3-(1 \mathrm{H}$-indol-3-yl)propyl)cyclopropanecarboxamide $(5.50 \mathrm{~g}, 22.7 \mathrm{mmol})$ in THF (30 mL), t-BuOH (30 mL) and water (10 mL), was treated portionwise with NBS $(12.1 \mathrm{~g}, 68.1 \mathrm{mmol})$. The mixture was stirred for $5 \mathrm{~h}$, then concentrated under vauum. The residue was then dissolved in DMF $(80 \mathrm{~mL})$, treated with $\mathrm{Cs}_{2} \mathrm{CO}_{3}(22.2 \mathrm{~g}, 68.1 \mathrm{mmol})$ and stirred for $30 \mathrm{~min}$. The reaction mixture was quenched with water (100 $\left.\mathrm{mL}\right)$ and extracted with DCM $(3 \times 150 \mathrm{~mL})$. The combined organic layers were washed with brine $(5 \times 150 \mathrm{~mL}), \mathrm{dried}\left(\mathrm{Na}_{2} \mathrm{SO}_{4}\right)$, filtered and concentrated. The residue was purified by chromatography on $\mathrm{SiO}_{2}(25 \%$ EtOAc/petroleum ether) providing 5-bromo-1'-

(cyclopropanecarbonyl)spiro[indoline-3,2'-pyrrolidin]-2-one (3.3 g, 43\%). ${ }^{1} \mathrm{H} \mathrm{NMR}\left(400 \mathrm{MHz}, \mathrm{DMSO}-d_{6}\right) \delta 10.40(\mathrm{~s}, 1 \mathrm{H}), 7.40(\mathrm{~s}, 1 \mathrm{H}), 7.32(\mathrm{dd}, J=$ 8.4, $2 \mathrm{~Hz}, 1 \mathrm{H}), 6.72(\mathrm{~d}, J=8 \mathrm{~Hz}, 1 \mathrm{H}), 4.08-4.03(\mathrm{~m}, 1 \mathrm{H}), 3.88-3.83(\mathrm{~m}, 1 \mathrm{H}), 2.30-2.10(\mathrm{~m}, 3 \mathrm{H}), 1.98-1.92(\mathrm{~m}, 1 \mathrm{H}), 1.85-1.79(\mathrm{~m}, 1 \mathrm{H}), 0.77-0.65(\mathrm{~m}$, $2 \mathrm{H}), 0.58(\mathrm{~m}, 2 \mathrm{H})$. MS (EI) calc'd for $\mathrm{C}_{15} \mathrm{H}_{16} \mathrm{BrN}_{2} \mathrm{O}_{2}[\mathrm{M}+\mathrm{H}]^{+}, 335,337$; found, 335, 337.

Step 3: A solution of 5-bromo-1'-(cyclopropanecarbonyl)spiro[indoline-3,2'-pyrrolidin]-2-one (2.1 g, $6.3 \mathrm{mmol}^{2}, \mathrm{NEt}_{3}(1.75 \mathrm{~mL}, 12.5 \mathrm{mmol})$ and $\operatorname{DMAP}(0.765 \mathrm{~g}, 6.26 \mathrm{mmol})$ in DCM $(50 \mathrm{~mL})$ was treated with di-tert-butyl dicarbonate $(1.64 \mathrm{~g}, 7.52 \mathrm{mmol})$ and stirred for $2 \mathrm{~h}$. The reaction mixture was quenched with water $(100 \mathrm{~mL})$ and extracted with DCM $(2 \times 100 \mathrm{~mL})$. The combined organic layers were washed with brine $(3 \times 100 \mathrm{~mL})$, dried $\left(\mathrm{Na}_{2} \mathrm{SO}_{4}\right)$ and concentrated. The residue was purified by chromatography on $\mathrm{SiO}_{2}$ (0-15\% EtOAc/petroleum ether) to afford tert-butyl 5-bromo-1'(cyclopropanecarbonyl)-2-oxospiro[indoline-3,2'-pyrrolidine]-1-carboxylate (2.40 g, 87\%). MS (EI) calc' d for $\mathrm{C}_{20} \mathrm{H}_{24} \mathrm{BrN}_{2} \mathrm{O}_{4}[\mathrm{M}+\mathrm{H}]^{+}, 435 ;$ found, 435 .

Step 4: A mixture of tert-butyl 5-bromo-1'-(cyclopropanecarbonyl)-2-oxospiro[indoline-3,2'-pyrrolidine]-1-carboxylate (2.40 g, 5.51 mmol), (BPin) 2 $(1.54 \mathrm{~g}, 6.06 \mathrm{mmol}), \mathrm{KOAc}(1.08 \mathrm{~g}, 11.0 \mathrm{mmol})$ and $\mathrm{PdCl}_{2}(\mathrm{dppf})(0.450 \mathrm{~g}, 0.551 \mathrm{mmol})$ in 1,4-dioxane $(20 \mathrm{~mL})$ was deoxygenated and stirred for $3 \mathrm{~h}$ at $80{ }^{\circ} \mathrm{C}$. The reaction mixture was filtered and concentrated. The residue was purified by chromatography on $\mathrm{SiO}_{2}(0 \mathrm{to} 15 \% \mathrm{EtOAc} / \mathrm{petroleum}$ ether) to afford the desired intermediate tert-butyl-1'-(cyclopropanecarbonyl)-2-oxo-5-(4,4,5,5-tetramethyl-1,3,2-dioxaborolan-2-yl)spiro[indoline3,2'-pyrrolidine]-1-carboxylate (2.20 g, 83\%). MS (EI) calc'd for $\mathrm{C}_{26} \mathrm{H}_{36} \mathrm{BN}_{2} \mathrm{O}_{6}[\mathrm{M}+\mathrm{H}]^{+}, 483$; found, 483.

Step 5: A mixture of tert-butyl 1'-(cyclopropanecarbonyl)-2-oxo-5-(4,4,5,5-tetramethyl-1,3,2-dioxaborolan-2-yl)spiro[indoline-3,2'-pyrrolidine]-1carboxylate (1.20 g, $2.49 \mathrm{mmol}), 6$-chloro-9-ethyl-8-(2-methyl-pyrimidin-5-yl)-9H-purine (0.683 g, $2.49 \mathrm{mmol}), \mathrm{PdCl} 2$ (dtbpf) (160 mg, $0.249 \mathrm{mmol})$ and $\mathrm{K}_{3} \mathrm{PO}_{4}(1.06 \mathrm{~g}, 4.98 \mathrm{mmol})$ in 1,4-dioxane $(15 \mathrm{~mL})$ and water $(3 \mathrm{~mL})$ was deoxygenated and stirred for $3 \mathrm{~h}$ at $80^{\circ} \mathrm{C}$. After cooling to room temperature, the reaction mixture was diluted EtOAc $(100 \mathrm{~mL})$, washed with brine $(2 \times 50 \mathrm{~mL})$, dried $\left(\mathrm{Na}_{2} \mathrm{SO}_{4}\right)$ and concentrated. The residue was purified by chromatography on $\mathrm{SiO}_{2}(0$ to $20 \% \mathrm{MeOH} / \mathrm{DCM})$ to afford the desired product tert-butyl 1'-(cyclopropanecarbonyl)-5-(9-ethyl-8-(2- 
methylpyrimidin-5-yl)-9H-purin-6-yl)-2-oxospiro[indoline-3,2'-pyrrolidine]-1-carboxylate (1.0 g, 68\%). MS (EI) calc'd for $\mathrm{C}_{32} \mathrm{H}_{35} \mathrm{~N}_{8} \mathrm{O}_{4}[\mathrm{M}+\mathrm{H}]^{+}, 595$; found, 595.

Step 6: A stirred solution of tert-butyl 1'-(cyclopropanecarbonyl)-5-(9-ethyl-8-(2-methylpyrimidin-5-yl)-9H-purin-6-yl)-2-oxospiro[indoline-3,2'pyrrolidine]-1-carboxylate $(600 \mathrm{mg}, 1.01 \mathrm{mmol})$ in EtOAc $(100 \mathrm{ml})$ was treated with $\mathrm{HCl}$ gas by having the gas bubble through the solution for $2 \mathrm{~h}$, then the resulting solution was stirred for another $3 \mathrm{~h}$. The reaction was concentrated under reduced pressure and the $\mathrm{pH}$ adjusted to 9 with aqueous sodium carbonate $(20 \mathrm{~mL})$. The resulting suspension was filtered, the filter cake washed with methanol $(3 \times 30 \mathrm{~mL})$. The solid was dried under reduced pressure to provide 1'-(cyclopropanecarbonyl)-5-(9-ethyl-8-(2-methylpyrimidin-5-yl)-9H-purin -6-yl)spiro[indoline-3,2'-pyrrolidin]-2one $(350 \mathrm{mg}, 70 \%) .{ }^{1} \mathrm{H}$ NMR $\left(300 \mathrm{MHz}, \mathrm{DMSO}-d_{6}\right) \delta 10.75(\mathrm{~s}, 1 \mathrm{H}), 9.26(\mathrm{~s}, 2 \mathrm{H}), 8.97(\mathrm{~s}, 1 \mathrm{H}), 8.90(\mathrm{dd}, J=8.1 \mathrm{~Hz}, 1.5 \mathrm{~Hz}, 1 \mathrm{H}), 8.60(\mathrm{~d}, J=1.5 \mathrm{~Hz}, 1$ H), $7.01(\mathrm{~d}, J=8.4 \mathrm{~Hz}, 1 \mathrm{H}), 4.45(\mathrm{q}, J=7.2 \mathrm{~Hz}, 2 \mathrm{H}), 4.16-4.11(\mathrm{~m}, 1 \mathrm{H}), 3.95-3.92(\mathrm{~m}, 1 \mathrm{H}), 2.79(\mathrm{~s}, 3 \mathrm{H}), 2.32-2.18(\mathrm{~m}, 3 \mathrm{H}), 2.07-2.02(\mathrm{~m}, 1 \mathrm{H}), 1.86-$ $1.84(\mathrm{~m}, 1 \mathrm{H}), 1.39(\mathrm{t}, J=7.2 \mathrm{~Hz}, 3 \mathrm{H}), 0.77-0.56(\mathrm{~m}, 4 \mathrm{H})$. MS (El) calc'd for $\mathrm{C}_{27} \mathrm{H}_{27} \mathrm{~N}_{8} \mathrm{O}_{2}[\mathrm{M}+\mathrm{H}]^{+}, 495$; found, 495.

Step 7: Racemic cyclopropanecarbonyl)-5-(9-ethyl-8-(2-methylpyrimidin-5-yl)-9H-purin-6-yl)spiro[indoline-3,2'-pyrrolidin]-2-one was dissolved in DMF and the enantiomers separated using chiral column chromatography [Column: Chiralpak IB, $21 \times 250 \mathrm{~mm} ; 220 \mathrm{~nm}$ detection; $70 \mathrm{~mL} / \mathrm{min}$ flow rate; $30 \% \mathrm{MeOH}$ and $0.25 \% \mathrm{Me}_{2} \mathrm{NEt}$ in $\mathrm{CO}_{2}$ ]. The faster eluting and more active enantiomer came at a retention time of $5.46 \mathrm{~min}(5 \mathrm{c}) ;$ while the slower eluting less active enantiomer came at a retention time of $6.29 \mathrm{~min}$. Characterization data for $5 \mathrm{c}:[\alpha]_{\mathrm{D}}-44^{\circ}(c=2.5 \mathrm{mg} / \mathrm{mL}, \mathrm{MeOH}) ;{ }^{1} \mathrm{H} \mathrm{NMR}$ $\left(600 \mathrm{MHz}, \mathrm{DMSO}-d_{6}\right) \delta 10.62(\mathrm{~s}, 1 \mathrm{H}), 9.22(\mathrm{~s}, 2 \mathrm{H}), 8.94(\mathrm{~s}, 1 \mathrm{H}), 8.86(\mathrm{~d}, J=8.2 \mathrm{~Hz}, 1 \mathrm{H}), 8.57(\mathrm{~s}, 1 \mathrm{H}), 6.97(\mathrm{~d}, J=8.2 \mathrm{~Hz}, 1 \mathrm{H}), 4.42(\mathrm{q}, J=7.3 \mathrm{~Hz}, 2 \mathrm{H})$, 4.12-4.09 (m, $1 \mathrm{H}), 3.92-3.88(\mathrm{~m}, 1 \mathrm{H}), 2.75(\mathrm{~s}, 3 \mathrm{H}), 2.27-2.25(\mathrm{~m}, 2 \mathrm{H}), 2.18-2.13(\mathrm{~m}, 1 \mathrm{H}), 2.03-2.00(\mathrm{~m}, 1 \mathrm{H}), 1.83-1.82(\mathrm{~m}, 1 \mathrm{H}), 1.35(\mathrm{t}, J=7.0 \mathrm{~Hz}, 3$ $\mathrm{H}), 0.72(\mathrm{~m}, 1 \mathrm{H}), 0.63(\mathrm{~m}, 1 \mathrm{H}), 0.54(\mathrm{~m}, 1 \mathrm{H}), 0.51(\mathrm{~m}, 1 \mathrm{H}) ;{ }^{13} \mathrm{C}$ NMR $\left(125 \mathrm{MHz}, \mathrm{DMSO}-d_{6}\right) \delta$ 178.3, 170.6, 169.4, 157.3 (2C), 153.9, 153.2, 152.5, $150.0,145.1,133.4,131.5,130.1,129.3,122.7,121.9,110.0,67.7,48.5,39.3,38.1,26.3,24.5,15.3,12.6,8.0,7.7$; HRMS (EI) calc'd for $\mathrm{C}_{27} \mathrm{H}_{27} \mathrm{~N}_{8} \mathrm{O}_{2}$ $[\mathrm{M}+\mathrm{H}]^{+}, 495.2257$; found, 495.2261 .

Step 8: A dilute solution of 1'-(cyclopropanecarbonyl)-5-(9-ethyl-8-(2-methylpyrimidin-5-yl)-9H-purin-6-yl)spiro[indoline-3,2'-pyrrolidin]-2-one (300 $\mathrm{mg}, 0.607 \mathrm{mmol})$ in DMF $(10 \mathrm{~mL})$ was treated with $60 \% \mathrm{NaH}(40 \mathrm{mg}, 1.0 \mathrm{mmol})$, stirred for $10 \mathrm{~min}$, then treated with iodomethane $(0.070 \mathrm{~mL}, 1.1$ $\mathrm{mmol})$. The reaction mixture was stirred for 1 hour at $20^{\circ} \mathrm{C}$. Diluted with $\mathrm{DCM}_{\text {and }}$ washed with water. The organic layer was dried $\left(\mathrm{Na}_{2} \mathrm{SO}_{4}\right)$ and concentrated. Chromatography on silica gel (100 g) with a gradient of 0-50\% 1:1 EtOAc/MeOH in DCM gave the desired product 5e. Data for 5e: $[\alpha]_{\mathrm{D}}-65^{\circ}(c=2.5 \mathrm{mg} / \mathrm{mL}, \mathrm{MeOH}) ;{ }^{1} \mathrm{H} \mathrm{NMR}\left(300 \mathrm{MHz}, \mathrm{DMSO}-d_{6}\right) \delta 9.26(\mathrm{~s}, 2 \mathrm{H}), 8.99(\mathrm{~s}, 1 \mathrm{H}), 8.97(\mathrm{~d}, J=7.2 \mathrm{~Hz}, 1 \mathrm{H}), 8.65(\mathrm{~d}, J=1.5 \mathrm{~Hz}, 1 \mathrm{H}), 7.21(\mathrm{~d}$, $J=8.1 \mathrm{~Hz}, 1 \mathrm{H}), 4.49-4.42(\mathrm{~m}, 2 \mathrm{H}), 4.17-4.14(\mathrm{~m}, 1 \mathrm{H}), 3.97-3.94(\mathrm{~m}, 1 \mathrm{H}), 3.18(\mathrm{~s}, 3 \mathrm{H}), 2.78(\mathrm{~s}, 3 \mathrm{H}), 2.34-2.03(\mathrm{~m}, 4 \mathrm{H}), 1.88-1.83(\mathrm{~m}, 1 \mathrm{H}), 1.39(\mathrm{t}, J$ $=7.2 \mathrm{~Hz}, 3 \mathrm{H}), 0.69-0.51(\mathrm{~m}, 4 \mathrm{H}) ;{ }^{13} \mathrm{C}$ NMR $\left(150 \mathrm{MHz}\right.$, DMSO-d $\left.\mathrm{d}_{6}\right)$ 176.7, 170.7, 169.4, 157.3 (2C), 154.0, 153.0, 152.5, 150.1, 146.4, 132.6, 131.5, $130.2,129.9,122.3,121.9,108.9,67.3,48.5,39.3,37.9,26.9,26.3,24.6,15.3,12.6,8.0,7.7 ; \mathrm{HRMS}(\mathrm{EI})$ calc'd for $\mathrm{C}_{28} \mathrm{H}_{29} \mathrm{~N}_{8} \mathrm{O}_{2}[\mathrm{M}+\mathrm{H}]^{+}, 509.2413$; found, 509.2425 . 


\section{Biochemical, Cell and Whole Blood Assay Protocols.}

PI3K Biochemical HTRF Assays. PI3K family biochemical potencies in the phosphorylation of PIP2 (phosphatidylinositol (4,5)-bisphosphate) to PIP3 (phosphatidylinositol $(3,4,5)$-trisphosphate) were measured using an HTRF assay. PI3K biochemical assays were optimized from an Upstate (Millipore) HTRF kit. Briefly, compounds were serially diluted (3-fold in 100\% DMSO) for a 10-concentration dose response. PI3K reaction buffer was prepared by dilution of stock with DI water, then treated with DTT, PIP2 and Biotin-PIP3 at a final concentration of $5 \mu \mathrm{M}, 5 \mu \mathrm{M}$ and $25 \mathrm{nM}$, respectively. Enzyme and the compounds were added at ambient temperature for a 15 min preincubation. Reactions were initiated by addition of substrate solution (PIP2 and ATP) and incubated at ambient temperature for $1 \mathrm{~h}$ before quenching with EDTA. The detection solution (streptavidinAPC with Eu-labeled anti-GST plus GST-tagged PH-domain) was added and incubated in the dark for $1 \mathrm{~h}$, followed by measurement of the HTRF signal with an Envision plate reader ( $330 \mathrm{~nm}$ excitation and dual emission detection at $620 \mathrm{~nm}$ (Eu) and $665 \mathrm{~nm}$ (APC)). The individual kinases were purchased from Upstate (PI3K $\alpha$ 14-602, PI3K $\beta$ 14-603, PI3K $\gamma$ 14-558 and PI3K $\delta$ 14-604). The assay format was the same for all four isoforms, the differences lie in the concentration of enzyme and ATP used. The PI3K $\alpha, \mathrm{PI} 3 \mathrm{~K} \beta, \mathrm{PI} 3 \mathrm{~K} \delta$, PI3K $\gamma$ assays were run with $0.5,1,0.3,5 \mathrm{nM}$ of enzyme, respectively. The ATP concentration was $100 \mu \mathrm{M}$ in the PI3K $\alpha, \mathrm{PI} 3 \mathrm{~K} \beta$, and PI3K $\delta$ assays and $50 \mu \mathrm{M}$ in the PI3K $\gamma$ assay. Assay run in duplicate.

Ramos AKT-pSer473 Assay. The phosphorylation status of serine 473 of AKT in the Ramos lymphoma-derived B cell line is driven by PI3K $\delta$, hence a good measure of cellular activity of PI3K $\delta$ inhibition. The Ramos cell line expresses cell surface IgM and responds to IgM crosslinking by activating $\mathrm{PI} 3 \mathrm{~K} \delta$-dependent signaling. The AlphaScreen SureFire Akt p-Ser473 assay was used to measure the phosphorylation of endogenous AKT in cellular lysates. B Lymphocyte Ramos cells (ATCC catalog \#CRL-1596) were split 1:3 every 3 to 4 days and maintained between 100,000-1,000,000 cells/mL. Cells were diluted in assay media (DMEM, high glucose, HEPES, No phenol red supplemented with sodium pyruvate) to a concentration of $10,000,000$ cells $/ \mathrm{mL}$ and plated ( $6 \mu \mathrm{L}, 60,000$ cells per well) using a BioRaptor. Compounds were serially diluted (3-fold in 100\% DMSO) for a 10 concentration dose response and $10 \mathrm{~nL}$ added to the wells. The mixture was preincubated for 20 min at ambient temperature. Anti-lgM ( $2 \mu \mathrm{L}$ of 1 $\mu \mathrm{g} / \mathrm{mL}$ ) was then added and the plates incubated at $37^{\circ} \mathrm{C}$ for $30 \mathrm{~min}$. The cells were then treated with Lysis buffer ( $2 \mu \mathrm{L}$ of $\left.5 \mathrm{x}\right)$ and incubated for 30 min at ambient temperature. In the dark, acceptor beads ( $8 \mu \mathrm{L}$ of $0.039 \mathrm{mg} / \mathrm{mL}$ ) were added with Ser473 reaction buffer and the plates incubated for $2 \mathrm{~h}$. Donor beads ( $3 \mu \mathrm{L}$ of $0.036 \mathrm{mg} / \mathrm{mL}$ ) were added in the dark and again incubated for $2 \mathrm{~h}$. The plates were then read on Envision plate reader. Assay run in duplicate.

Human Whole Blood B-Cell Activation CD69 Biomarker Assay. B cell activation is linked to a broad number of diseases including oncology, arthritis, and lupus. Activation of B-cells can be induced ex vivo by stimulation with antibodies that recognize components of the B-cell receptor. These antibodies crosslink receptors on the surface of the B-cell, inducing receptor signaling cascade that drives cell activation. The B-cell receptor is composed of three subunits: a transmembrane IgM for antigen recognition, and CD79a and CD79b, with small cell surface epitopes and prominent intracellular domains containing ITAM signaling subunits. Human whole blood was obtained from healthy volunteer donors at Merck Sharp \& Dohme Corp., a subsidiary of Merck \& Co., Inc., Kenilworth, NJ, USA. Using an Echo liquid handler, $120 \mathrm{~nL}$ of compound in DMSO at varying concentrations in a 96-well plate was then treated with $100 \mu \mathrm{L}$ of blood and incubated for 60 min at $37^{\circ} \mathrm{C}$. To each well was added $11 \mu \mathrm{L}$ of anti$\mathrm{CD} 76 \mathrm{~b}$ antibody (BD Biosciences) and the mixture incubated for $3 \mathrm{~h}$ at $37^{\circ} \mathrm{C}$. The reaction was stopped by placing on wet ice for 5 min. Each well was treated with $50 \mu \mathrm{L}$ of staining cocktail (CD45-V450, $5 \mu \mathrm{L}$; CD3-APC, $5 \mu \mathrm{L}$; CD20-PerCP-Cy5-5, 7.5 $\mu \mathrm{L}$; CD69-FITC, $20 \mu \mathrm{L}$ in FACS Buffer, $12.5 \mu \mathrm{L}$; all from BD Biosciences). The mixture was incubated for $30 \mathrm{~min}$ at $4{ }^{\circ} \mathrm{C}$. RBCs were lysed by adding $1.8 \mathrm{~mL}$ FACS lysis buffer to each well, incubated for $20 \mathrm{~min}$ at $20^{\circ} \mathrm{C}$. Spin down plate at $1000 \mathrm{xg}$ for $5 \mathrm{~min}$, remove supernatant, and tap plate on an absorbent pad to remove excess liquid. Resuspend pellet in each well in $250 \mu \mathrm{L}$ of FACS reading buffer ( 1 X BD stain buffer, $0.5 \%$ Pluronic F68, $0.2 \mathrm{mg} / \mathrm{mL}$ human IgG), and transfer cells to a clean 384 well u-bottom greiner plate. Fixed and stained cells are kept at $4{ }^{\circ} \mathrm{C}$ before analyzing fluorescence with Fortessa A FACS machine. Gating: Gate1 = Lymphocyte, based on CD45 and side scatter; Gate2 = Singlet (from gate1), based on forward scatter A\&H; Gate3 = B cell (from gate2), which are CD3-APC negative and CD20-PerCP Cy5.5 positive; Gate4 = Activated B cell (from gate3), which are CD69-FITC positive. Assay run in duplicate.

HeLa Cell Adenosine Uptake (AdU) Inhibition Assay. Dilution plates with compound in DMSO were prepared as a 10-point titration and diluted with HBSS with $5 \%$ FBS to reach concentrations of $25000 \mathrm{nM}$ to $0.8 \mathrm{nM}$ of compound. HeLa cells (ATCC) were thawed and seeded 25,000 cells/well in Cytostar T plates overnight in MEM and 10\% FBS. Remove growth media by flicking, add $40 \mu \mathrm{L}$ of HBSS with $5 \%$ FBS, then add $40 \mu \mathrm{L}$ of compound in buffer onto the cells. Incubate for $30 \mathrm{~min}$. Add $20 \mu \mathrm{L}$ of radiolabeled $100 \mathrm{nM} 3 \mathrm{H}$-adenosine (ARC; $40 \mathrm{Ci} / \mathrm{mmol} \mathrm{specific} \mathrm{activity} \mathrm{and} 1$ $\mathrm{mCi} / \mathrm{mL}$ concentration from $25000 \mathrm{nM}$ stock concentration) in HBSS with $5 \% \mathrm{FBS}$, and incubate for 60 min. Total volume $100 \mu \mathrm{L}$, with compound concentrations of $10000 \mathrm{nM}$ to $0.32 \mathrm{nM}$. To measure uptake of radioactive adenosine, plates were read with PerkinElmer TopCount NXT HTS plate reader. Data was analyzed using ADA Logic to fit to a 4-parameter fit to provide $\mathrm{IC}_{50}$ values. Assay run in duplicate. 
Broad Kinome Selectivity

Screening performed at Invitrogen (Thermofisher). Data for compounds 4c, 4d, 5d, 5e displayed in the table below.

\begin{tabular}{|c|c|c|c|c|}
\hline Kinase & $\begin{array}{l}\text { Compound 4c } \\
I C_{50}(\mu \mathrm{M})\end{array}$ & $\begin{array}{l}\text { Compound 4d } \\
I_{50}(\mu \mathrm{M})\end{array}$ & $\begin{array}{l}\text { Compound 5d } \\
I_{50}(\mu \mathrm{M})\end{array}$ & $\begin{array}{l}\text { Compound } 5 \mathrm{e} \\
\mathrm{IC}_{50}(\mu \mathrm{M})\end{array}$ \\
\hline ABL1 & $>100$ & $>100$ & $>100$ & $>100$ \\
\hline ABL1(E255K) & $>100$ & $>100$ & $>100$ & \\
\hline ABL1(G250E) & $>100$ & $>100$ & $>100$ & \\
\hline ABL1(T315I) & $>100$ & $>100$ & $>100$ & \\
\hline ABL1(Y253F) & $>100$ & $>100$ & $>100$ & \\
\hline ABL2(ARG) & $>100$ & $>100$ & $>100$ & \\
\hline ADRBK1 & $>100$ & $>100$ & $>100$ & \\
\hline ADRBK2 & $>100$ & $>100$ & $>100$ & \\
\hline AKT1 Alpha & $>100$ & 31.16 & $>100$ & $>100$ \\
\hline AKT2 Beta & $>100$ & $>100$ & $>100$ & \\
\hline AKT2 Gamma & $>100$ & $>100$ & $>100$ & \\
\hline ALK4 & $>100$ & $>100$ & $>100$ & $>100$ \\
\hline $\begin{array}{l}\text { AMPK Alpha1 Beta1 } \\
\text { Gamma1 }\end{array}$ & $>100$ & $>100$ & $>100$ & 6.915 \\
\hline $\begin{array}{l}\text { AMPK Apha2 Beta1 } \\
\text { Gamma1 }\end{array}$ & $>100$ & $>100$ & $>100$ & \\
\hline AURKA & $>100$ & $>100$ & $>100$ & \\
\hline AURKB & $>100$ & $>100$ & $>100$ & 7.289 \\
\hline AURKC & $>100$ & $>100$ & $>100$ & \\
\hline AXL & $>100$ & $>100$ & $>100$ & \\
\hline BLK & $>100$ & $>100$ & $>100$ & \\
\hline BMX & $>100$ & $>100$ & $>100$ & $>100$ \\
\hline BRAF & 28.3 & $>100$ & $>100$ & $>100$ \\
\hline BRAF(V599E) & $>100$ & $>100$ & $>100$ & \\
\hline BRSK1 & $>100$ & $>100$ & $>100$ & \\
\hline BTK & $>100$ & $>100$ & $>100$ & $>100$ \\
\hline CAMK I Alpha & $>100$ & $>100$ & $>100$ & \\
\hline CAMK I Delta & $>100$ & $>100$ & $>100$ & \\
\hline CAMK II Alpha & $>100$ & $>100$ & $>100$ & \\
\hline CAMK II Beta & $>100$ & $>100$ & $>100$ & \\
\hline CAMK II Delta & $>100$ & $>100$ & $>100$ & \\
\hline CAMK4 & $>100$ & $>100$ & $>100$ & $>100$ \\
\hline CDC42BPA & $>100$ & $>100$ & $>100$ & \\
\hline CDC42BPB & $>100$ & $>100$ & $>100$ & \\
\hline CDK1 & $>100$ & $>100$ & $>100$ & \\
\hline CDK2 & $>100$ & $>100$ & $>100$ & $>100$ \\
\hline CDK5/P25 & $>100$ & $>100$ & $>100$ & $>100$ \\
\hline CDK5/P35 & $>100$ & $>100$ & $>100$ & \\
\hline CDK7 & 28.99 & $>100$ & $>100$ & $>100$ \\
\hline CDK9(CYCLIN T1) & $>100$ & $>100$ & $>100$ & $>100$ \\
\hline CHEK1 & $>100$ & $>100$ & $>100$ & $>100$ \\
\hline CHEK2 & $>100$ & $>100$ & $>100$ & $>100$ \\
\hline CLK1 & $>100$ & $>100$ & $>100$ & \\
\hline CLK2 & $>100$ & $>100$ & $>100$ & $>100$ \\
\hline CLK3 & $>100$ & $>100$ & $>100$ & \\
\hline CSF1R & $>100$ & $>100$ & $>100$ & $>100$ \\
\hline CSK & $>100$ & $>100$ & $>100$ & \\
\hline CSNK1A1 & $>100$ & $>100$ & $>100$ & $>100$ \\
\hline CSNK1D & $>100$ & $>100$ & $>100$ & \\
\hline
\end{tabular}




\begin{tabular}{|c|c|c|c|c|}
\hline CSNK1E & $>100$ & $>100$ & $>100$ & \\
\hline CSNK1G1 & $>100$ & $>100$ & $>100$ & \\
\hline CSNK1G2 & $>100$ & $>100$ & $>100$ & \\
\hline CSNK1G3 & $>100$ & $>100$ & $>100$ & \\
\hline CSNK2A1 & $>100$ & $>100$ & $>100$ & \\
\hline CSNK2A2 & $>100$ & $>100$ & $>100$ & \\
\hline DAPK1 & $>100$ & $>100$ & $>100$ & $>100$ \\
\hline DAPK3 & $>100$ & $>100$ & $>100$ & \\
\hline DCAMKL2 & $>100$ & $>100$ & $>100$ & \\
\hline DNA-PK & 7.27 & 5.099 & 2.918 & 0.513 \\
\hline DYRK1A & $>100$ & $>100$ & $>100$ & $>100$ \\
\hline DYRK1B & $>100$ & $>100$ & $>100$ & \\
\hline DYRK3 & $>100$ & $>100$ & $>100$ & \\
\hline DYRK4 & $>100$ & $>100$ & $>100$ & \\
\hline EEF2K & $>100$ & $>100$ & $>100$ & \\
\hline EGFR & $>100$ & $>100$ & $>100$ & $>100$ \\
\hline EGFR(L858R) & $>100$ & $>100$ & $>100$ & \\
\hline EGFR(L861Q) & $>100$ & $>100$ & $>100$ & \\
\hline EGFR(T790M L858R) & $>100$ & $>100$ & $>100$ & \\
\hline EGFR(T790M) & $>100$ & $>100$ & $>100$ & \\
\hline EPHA1 & $>100$ & $>100$ & $>100$ & \\
\hline EPHA2 & $>100$ & $>100$ & $>100$ & \\
\hline EPHA3 & $>100$ & $>100$ & $>100$ & $>100$ \\
\hline EPHA4 & $>100$ & $>100$ & $>100$ & \\
\hline EPHA5 & $>100$ & $>100$ & $>100$ & \\
\hline EPHA8 & $>100$ & $>100$ & $>100$ & \\
\hline EPHB1 & $>100$ & $>100$ & $>100$ & \\
\hline EPHB2 & $>100$ & $>100$ & $>100$ & $>100$ \\
\hline EPHB3 & $>100$ & $>100$ & $>100$ & \\
\hline EPHB4 & $>100$ & $>100$ & $>100$ & \\
\hline ERBB2 & $>100$ & $>100$ & $>100$ & \\
\hline ERBB4 & $>100$ & $>100$ & $>100$ & \\
\hline FER & $>100$ & $>100$ & $>100$ & \\
\hline FES & $>100$ & $>100$ & $>100$ & \\
\hline FGFR1 & $>100$ & $>100$ & $>100$ & \\
\hline FGFR2 & $>100$ & $>100$ & $>100$ & $>100$ \\
\hline FGFR3 & $>100$ & $>100$ & $>100$ & \\
\hline FGFR3(K650E) & $>100$ & $>100$ & $>100$ & \\
\hline FGFR4 & $>100$ & $>100$ & $>100$ & \\
\hline FGR & $>100$ & $>100$ & $>100$ & \\
\hline FLT1 & $>100$ & $>100$ & $>100$ & \\
\hline FLT3 & $>100$ & $>100$ & $>100$ & $>100$ \\
\hline FLT3(D835Y) & $>100$ & $>100$ & $>100$ & \\
\hline FLT4 & $>100$ & $>100$ & $>100$ & \\
\hline FRAP1(MTOR) & $>100$ & $>100$ & $>100$ & $>100$ \\
\hline FRK & $>100$ & $>100$ & $>100$ & \\
\hline FYN & $>100$ & $>100$ & $>100$ & \\
\hline GRK4 & $>100$ & $>100$ & $>100$ & $>100$ \\
\hline GRK5 & $>100$ & $>100$ & $>100$ & \\
\hline GRK6 & $>100$ & $>100$ & $>100$ & \\
\hline GRK7 & $>100$ & $>100$ & $>100$ & \\
\hline GSG2 & $>100$ & $>100$ & $>100$ & \\
\hline GSK3A & $>100$ & $>100$ & $>100$ & \\
\hline
\end{tabular}




\begin{tabular}{|c|c|c|c|c|}
\hline GSK3B & $>100$ & $>100$ & $>100$ & $>100$ \\
\hline $\mathrm{HCK}$ & $>100$ & $>100$ & $>100$ & $>100$ \\
\hline HIPK1 & $>100$ & $>100$ & $>100$ & \\
\hline HIPK2 & $>100$ & $>100$ & $>100$ & \\
\hline HIPK3 (YAK1) & $>100$ & $>100$ & $>100$ & \\
\hline HIPK4 & $>100$ & $>100$ & $>100$ & \\
\hline IGF1R & $>100$ & $>100$ & $>100$ & \\
\hline IKK Beta & $>100$ & $>100$ & $>100$ & $>100$ \\
\hline IKK Epsilon & $>100$ & $>100$ & $>100$ & \\
\hline IKKA & $>100$ & $>100$ & $>100$ & \\
\hline INSR & $>100$ & $>100$ & $>100$ & $>100$ \\
\hline INSRR & $>100$ & $>100$ & $>100$ & \\
\hline IRAK1 & $>100$ & $>100$ & $>100$ & $>100$ \\
\hline IRAK4 & $>100$ & $>100$ & $>100$ & $>100$ \\
\hline ITK & $>100$ & $>100$ & $>100$ & $>100$ \\
\hline JAK1 & $>100$ & $>100$ & $>100$ & $>100$ \\
\hline JAK2 & $>100$ & $>100$ & $>100$ & \\
\hline JAK2 JH1 JH2 (V617F) & $>100$ & $>100$ & $>100$ & \\
\hline JAK2 JH1 JH2 MT & $>100$ & $>100$ & $>100$ & \\
\hline JAK3 & $>100$ & $>100$ & $>100$ & \\
\hline KDR & $>100$ & $>100$ & $>100$ & $>100$ \\
\hline KIT & $>100$ & $>100$ & $>100$ & $>100$ \\
\hline KIT(T670I) & $>100$ & $>100$ & $>100$ & \\
\hline LCK & $>100$ & $>100$ & $>100$ & $>100$ \\
\hline LRRK2 & $>100$ & $>100$ & $>100$ & $>100$ \\
\hline LRRK2 (G2019S) & $>100$ & $>100$ & $>100$ & \\
\hline LTK & $>100$ & $>100$ & $>100$ & \\
\hline LYN & $>100$ & $>100$ & $>100$ & \\
\hline LYNB & $>100$ & $>100$ & $>100$ & \\
\hline MAP2K1 & 51.14 & $>100$ & 28.54 & 11.37 \\
\hline MAP2K2 & $>100$ & $>100$ & $>100$ & \\
\hline MAP2K6 & $>100$ & $>100$ & $>100$ & $>100$ \\
\hline MAP3K8 & $>100$ & $>100$ & $>100$ & \\
\hline MAР3К9 & $>100$ & $>100$ & $>100$ & \\
\hline MAPK1 & $>100$ & $>100$ & $>100$ & 22.21 \\
\hline MAPK10 & $>100$ & $>100$ & $>100$ & \\
\hline MAPK11 & $>100$ & $>100$ & $>100$ & \\
\hline MAPK12 & $>100$ & $>100$ & $>100$ & \\
\hline MAPK13 & $>100$ & $>100$ & $>100$ & $>100$ \\
\hline $\begin{array}{l}\text { MAPK14 (P38 } \\
\text { Alpha/INACTIVE } \\
\text { MAPKAPK2) }\end{array}$ & $>100$ & $>100$ & $>100$ & \\
\hline MAPK14 Alpha & $>100$ & $>100$ & $>100$ & $>100$ \\
\hline MAPK3(ERK1) & $>100$ & $>100$ & $>100$ & \\
\hline MAPK8 & $>100$ & $>100$ & 38.11 & 10.15 \\
\hline MAPK9 & $>100$ & $>100$ & $>100$ & \\
\hline MAPKAPK2 & $>100$ & $>100$ & $>100$ & $>100$ \\
\hline MAPKAРК3 & $>100$ & $>100$ & $>100$ & \\
\hline MAPKAPK5 & $>100$ & $>100$ & $>100$ & \\
\hline MARK1 & $>100$ & $>100$ & $>100$ & \\
\hline MARK2 & $>100$ & $>100$ & $>100$ & $>100$ \\
\hline MARK3 & $>100$ & $>100$ & $>100$ & \\
\hline MARK4 & $>100$ & $>100$ & $>100$ & \\
\hline
\end{tabular}




\begin{tabular}{|c|c|c|c|c|}
\hline MATK & $>100$ & $>100$ & $>100$ & \\
\hline MELK & $>100$ & $>100$ & $>100$ & \\
\hline MERTK & $>100$ & $>100$ & $>100$ & \\
\hline MET & $>100$ & $>100$ & $>100$ & 37.87 \\
\hline MET(M1250T) & $>100$ & $>100$ & $>100$ & \\
\hline MKNK1 & $>100$ & $>100$ & $>100$ & \\
\hline MST1R & $>100$ & $>100$ & $>100$ & \\
\hline MST4 & $>100$ & $>100$ & $>100$ & $>100$ \\
\hline MUSK & $>100$ & $>100$ & $>100$ & \\
\hline MYLK2 & $>100$ & $>100$ & $>100$ & \\
\hline NEK1 & $>100$ & $>100$ & $>100$ & \\
\hline NEK2 & $>100$ & $>100$ & $>100$ & $>100$ \\
\hline NEK4 & $>100$ & $>100$ & $>100$ & $>100$ \\
\hline NEK6 & $>100$ & $>100$ & $>100$ & \\
\hline NEK7 & $>100$ & $>100$ & $>100$ & \\
\hline NEK9 & $>100$ & $>100$ & $>100$ & \\
\hline NTRK1 & $>100$ & $>100$ & $>100$ & $>100$ \\
\hline NTRK2 & $>100$ & $>100$ & $>100$ & \\
\hline NTRK3 & $>100$ & $>100$ & $>100$ & \\
\hline NUAK1 & $>100$ & $>100$ & $>100$ & $>100$ \\
\hline PAK1 & $>100$ & $>100$ & $>100$ & $>100$ \\
\hline PAK2 & $>100$ & $>100$ & 89.19 & \\
\hline PAK2 & $>100$ & $>100$ & $>100$ & \\
\hline PAK3 & $>100$ & $>100$ & $>100$ & \\
\hline PAK4 & $>100$ & $>100$ & $>100$ & \\
\hline PAK7 & $>100$ & $>100$ & $>100$ & \\
\hline PASK & $>100$ & $>100$ & $>100$ & \\
\hline PDGFRA & $>100$ & $>100$ & $>100$ & \\
\hline PDGFRA(D842V) & $>100$ & $>100$ & $>100$ & \\
\hline PDGFRA(T674I) & $>100$ & $>100$ & $>100$ & \\
\hline PDGFRA(V561D) & $>100$ & $>100$ & $>100$ & \\
\hline PDGFRB & $>100$ & $>100$ & $>100$ & \\
\hline PDK1 & $>100$ & $>100$ & $>100$ & $>100$ \\
\hline PHK Gamma1 & $>100$ & $>100$ & $>100$ & \\
\hline PHKG2 & $>100$ & $>100$ & $>100$ & \\
\hline PI4K Alpha & $>100$ & $>100$ & $>100$ & $>100$ \\
\hline PI4K Beta & $>100$ & $>100$ & 37.56 & $>100$ \\
\hline PI3KC2 Alpha & $>100$ & $>100$ & 27.51 & $>100$ \\
\hline PI3KC2 Beta & 37.3 & $>100$ & 15.48 & $>100$ \\
\hline PI3KC3 & 34.44 & $>100$ & 30.99 & 42.68 \\
\hline PI3KC Gamma & 2.805 & 4.235 & 2.265 & 3.305 \\
\hline PI3KC Alpha (PI3K $\alpha)$ & 4.939 & 4.397 & 2.642 & 0.934 \\
\hline PI3KC Delta (PI3K $\delta)$ & 0.0057 & 0.0038 & 0.0019 & 0.0022 \\
\hline PI3KC Beta & 30.96 & 43.51 & $>100$ & $>100$ \\
\hline PIM1 & $>100$ & $>100$ & $>100$ & $>100$ \\
\hline PIM2 & $>100$ & $>100$ & $>100$ & \\
\hline PKG2 & $>100$ & $>100$ & $>100$ & $>100$ \\
\hline PKN1 & $>100$ & $>100$ & $>100$ & $>100$ \\
\hline PLK1 & $>100$ & $>100$ & $>100$ & $>100$ \\
\hline PLK2 & $>100$ & $>100$ & $>100$ & \\
\hline PLK3 & 20.96 & $>100$ & $>100$ & \\
\hline PRKACA & $>100$ & $>100$ & $>100$ & $>100$ \\
\hline PRKCA & $>100$ & $>100$ & $>100$ & \\
\hline
\end{tabular}




\begin{tabular}{|c|c|c|c|c|}
\hline PRKCB1 & $>100$ & $>100$ & $>100$ & \\
\hline PRKCB2 & $>100$ & $>100$ & $>100$ & \\
\hline PRKCD & 34.19 & 26.33 & $>100$ & \\
\hline PRKCE & $>100$ & $>100$ & $>100$ & \\
\hline PRKCG & $>100$ & $>100$ & $>100$ & \\
\hline PRKCH & $>100$ & $>100$ & $>100$ & \\
\hline PRKCl & 31 & $>100$ & $>100$ & $>100$ \\
\hline PRKCN & $>100$ & $>100$ & $>100$ & \\
\hline PRKCQ & $>100$ & $>100$ & $>100$ & $>100$ \\
\hline PRKCZ & $>100$ & $>100$ & $>100$ & \\
\hline PRKD1 & $>100$ & $>100$ & $>100$ & \\
\hline PRKD2 & $>100$ & $>100$ & $>100$ & \\
\hline PRKG1 & $>100$ & $>100$ & $>100$ & \\
\hline PRKX & $>100$ & $>100$ & $>100$ & \\
\hline PTK2 & $>100$ & $>100$ & $>100$ & \\
\hline PTK2B & $>100$ & $>100$ & $>100$ & \\
\hline PTK6 & $>100$ & $>100$ & $>100$ & $>100$ \\
\hline RAF1(Y340D Y341D) & $>100$ & $>100$ & $>100$ & $>100$ \\
\hline RET & $>100$ & $>100$ & $>100$ & \\
\hline RET(V804L) & $>100$ & $>100$ & $>100$ & \\
\hline RET(Y791F) & $>100$ & $>100$ & $>100$ & \\
\hline ROCK1 & $>100$ & $>100$ & $>100$ & 25.86 \\
\hline ROCK2 & $>100$ & $>100$ & $>100$ & \\
\hline ROS1 & $>100$ & $>100$ & $>100$ & \\
\hline RPS6KA1 & $>100$ & $>100$ & $>100$ & \\
\hline RPS6KA2 & $>100$ & $>100$ & $>100$ & \\
\hline RPS6KA3 & $>100$ & $>100$ & $>100$ & \\
\hline RPS6KA4 & $>100$ & $>100$ & $>100$ & \\
\hline RPS6KA5 & $>100$ & $>100$ & $>100$ & \\
\hline RPS6KA6 & $>100$ & $>100$ & $>100$ & $>100$ \\
\hline RPS6KB1 & $>100$ & $>100$ & $>100$ & 11.83 \\
\hline SGK & $>100$ & $>100$ & $>100$ & $>100$ \\
\hline SGK2 & $>100$ & $>100$ & $>100$ & \\
\hline SGKL & $>100$ & $>100$ & $>100$ & \\
\hline SNF1LK2 & $>100$ & $>100$ & $>100$ & \\
\hline SPHK1 & $>100$ & $>100$ & $>100$ & \\
\hline SPHK2 & $>100$ & $>100$ & $>100$ & \\
\hline SRC & $>100$ & $>100$ & $>100$ & $>100$ \\
\hline SRC N1 & $>100$ & $>100$ & $>100$ & \\
\hline SRMS & $>100$ & $>100$ & $>100$ & \\
\hline SRPK1 & $>100$ & $>100$ & $>100$ & \\
\hline SRPK2 & $>100$ & $>100$ & $>100$ & \\
\hline STK22B & $>100$ & $>100$ & $>100$ & \\
\hline STK22D & $>100$ & $>100$ & $>100$ & $>100$ \\
\hline STK23 & $>100$ & $>100$ & $>100$ & \\
\hline STK24 & $>100$ & $>100$ & $>100$ & \\
\hline STK25 & $>100$ & $>100$ & $>100$ & \\
\hline STK3 & $>100$ & $>100$ & $>100$ & \\
\hline STK4 & $>100$ & $>100$ & $>100$ & \\
\hline SYK & $>100$ & $>100$ & 24.14 & $>100$ \\
\hline TAOK2 & $>100$ & $>100$ & $>100$ & $>100$ \\
\hline TBK1 & $>100$ & $>100$ & $>100$ & $>100$ \\
\hline TEK & $>100$ & $>100$ & $>100$ & \\
\hline
\end{tabular}




\begin{tabular}{|l|l|l|l|l|}
\hline TXK & $>100$ & 32.55 & $>100$ & \\
\hline TYK2 & $>100$ & $>100$ & $>100$ & \\
\hline TYRO3 & $>100$ & $>100$ & $>100$ & \\
\hline YES1 & $>100$ & $>100$ & $>100$ & \\
\hline ZAP70 & $>100$ & $>100$ & $>100$ & \\
\hline
\end{tabular}

\section{High Dose Rat PK}

Obtained as a solution in 20/60/20-DMSO/PEG400/ $\mathrm{H}_{2} \mathrm{O}$ (1 mpk) or suspension in $10 \%$ Tween 80 (higher doses).

Compound 4d:

\begin{tabular}{|l|l|l|l|}
\hline Dose $(\mathrm{mg} / \mathrm{kg})$ & AUC $(\mu \mathrm{M}-\mathrm{hr})$ & Normalized AUC $(\mu \mathrm{M}-\mathrm{hr})$ & $\mathrm{Cmax}(\mu \mathrm{M})$ \\
\hline 1 & 1.6 & 1.6 & 0.36 \\
\hline 10 & 19 & 1.9 & 4.4 \\
\hline 30 & 69 & 2.3 & 8.5 \\
\hline 100 & 390 & 3.9 & 26 \\
\hline
\end{tabular}

Compound 5d:

\begin{tabular}{|l|l|l|l|}
\hline Dose $(\mathrm{mg} / \mathrm{kg})$ & AUC $(\mu \mathrm{M}-\mathrm{hr})$ & Normalized AUC $(\mu \mathrm{M}-\mathrm{hr})$ & $\mathrm{Cmax}(\mu \mathrm{M})$ \\
\hline 1 & 1.7 & 1.7 & 0.29 \\
\hline 10 & 5.6 & 0.56 & 2.9 \\
\hline 50 & 54 & 1.1 & 18 \\
\hline 200 & 490 & 2.4 & 52 \\
\hline
\end{tabular}




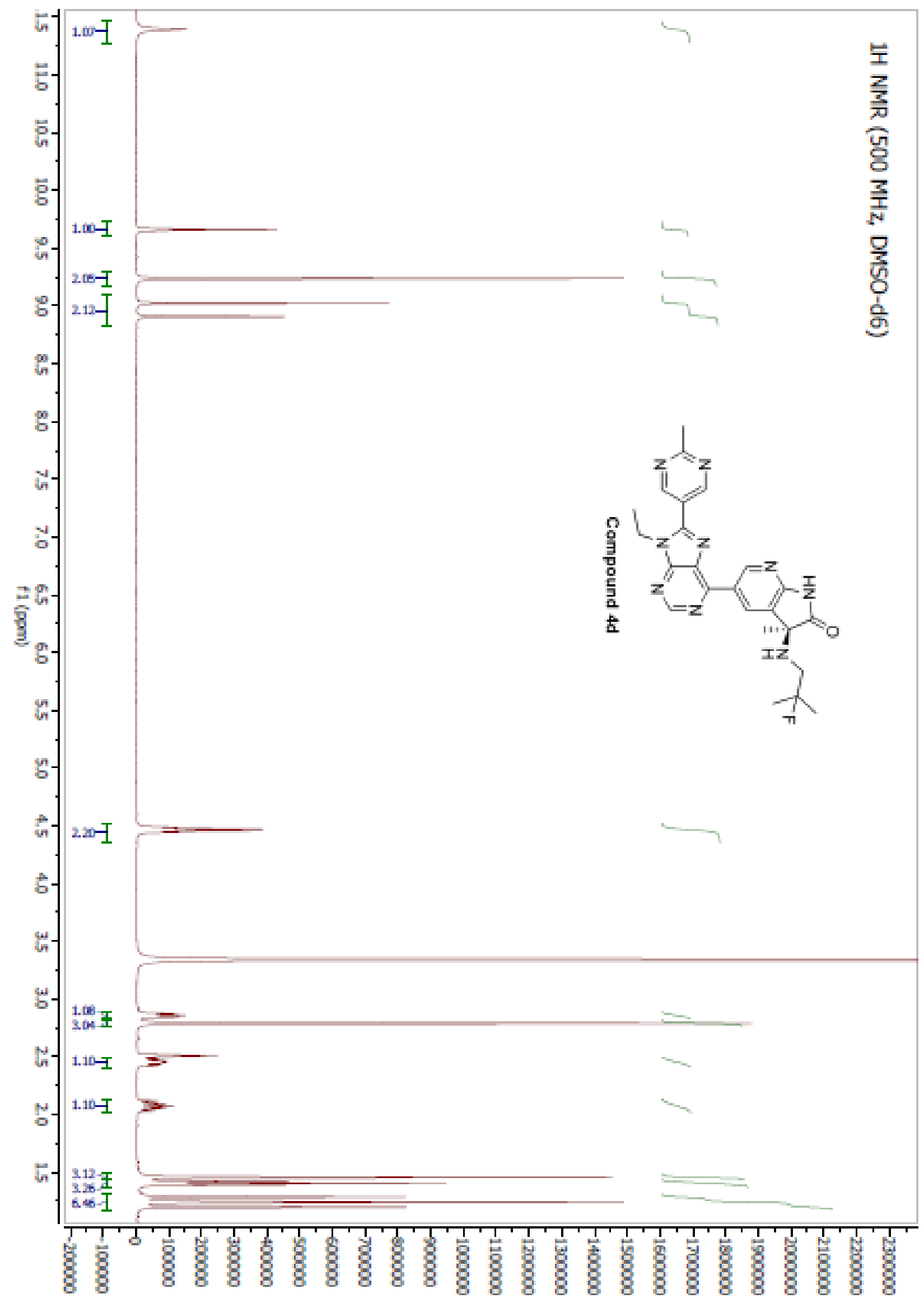




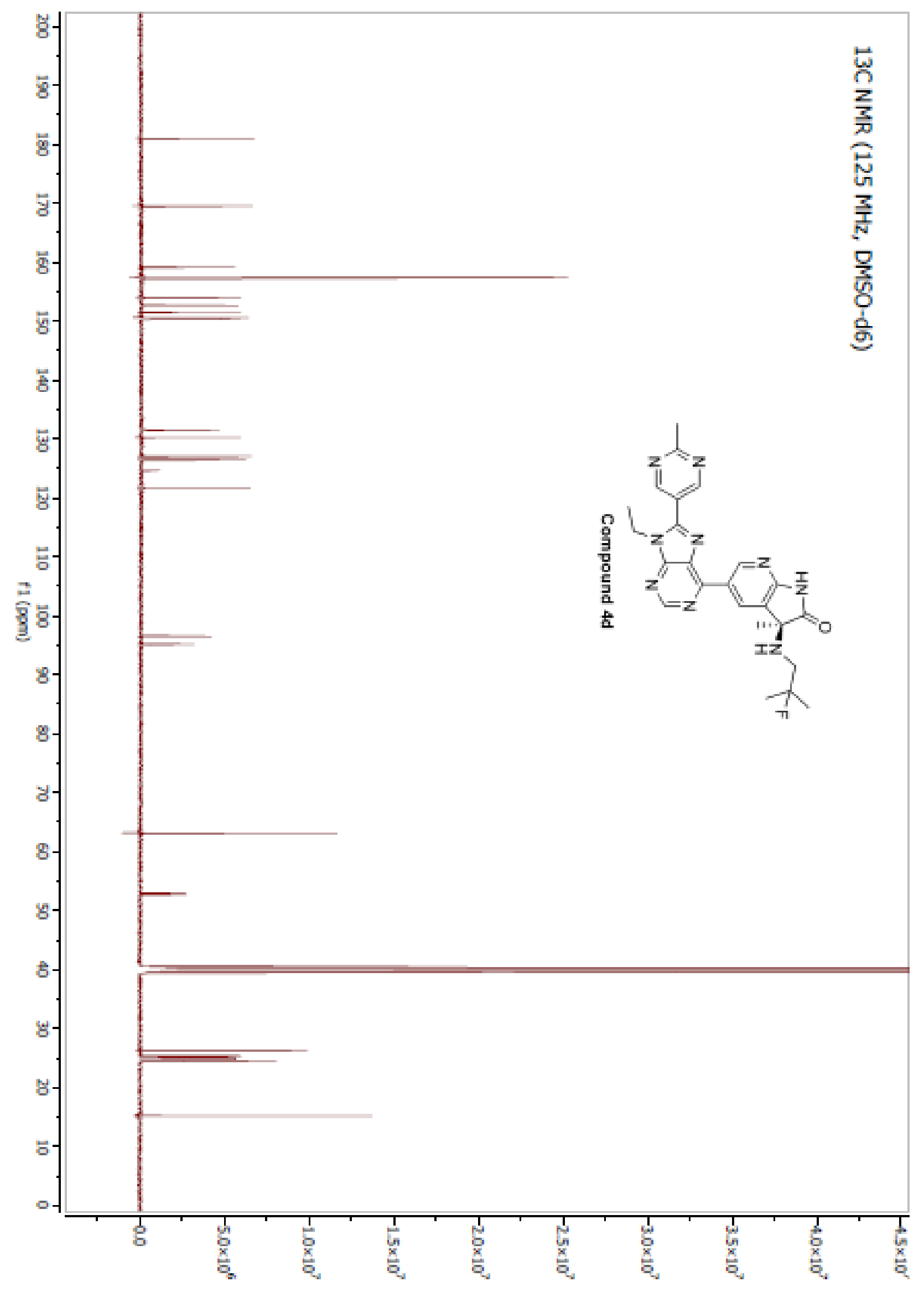




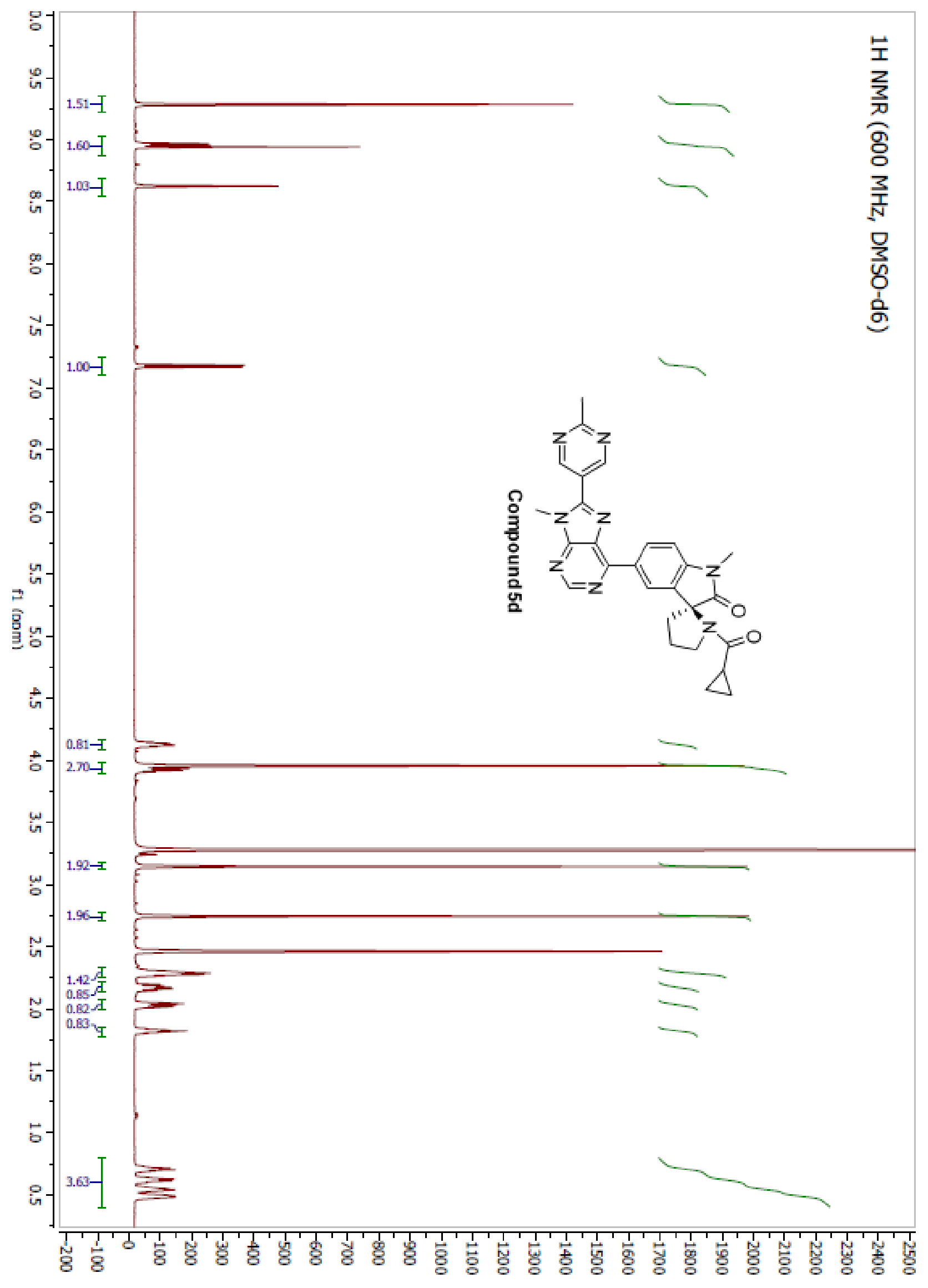




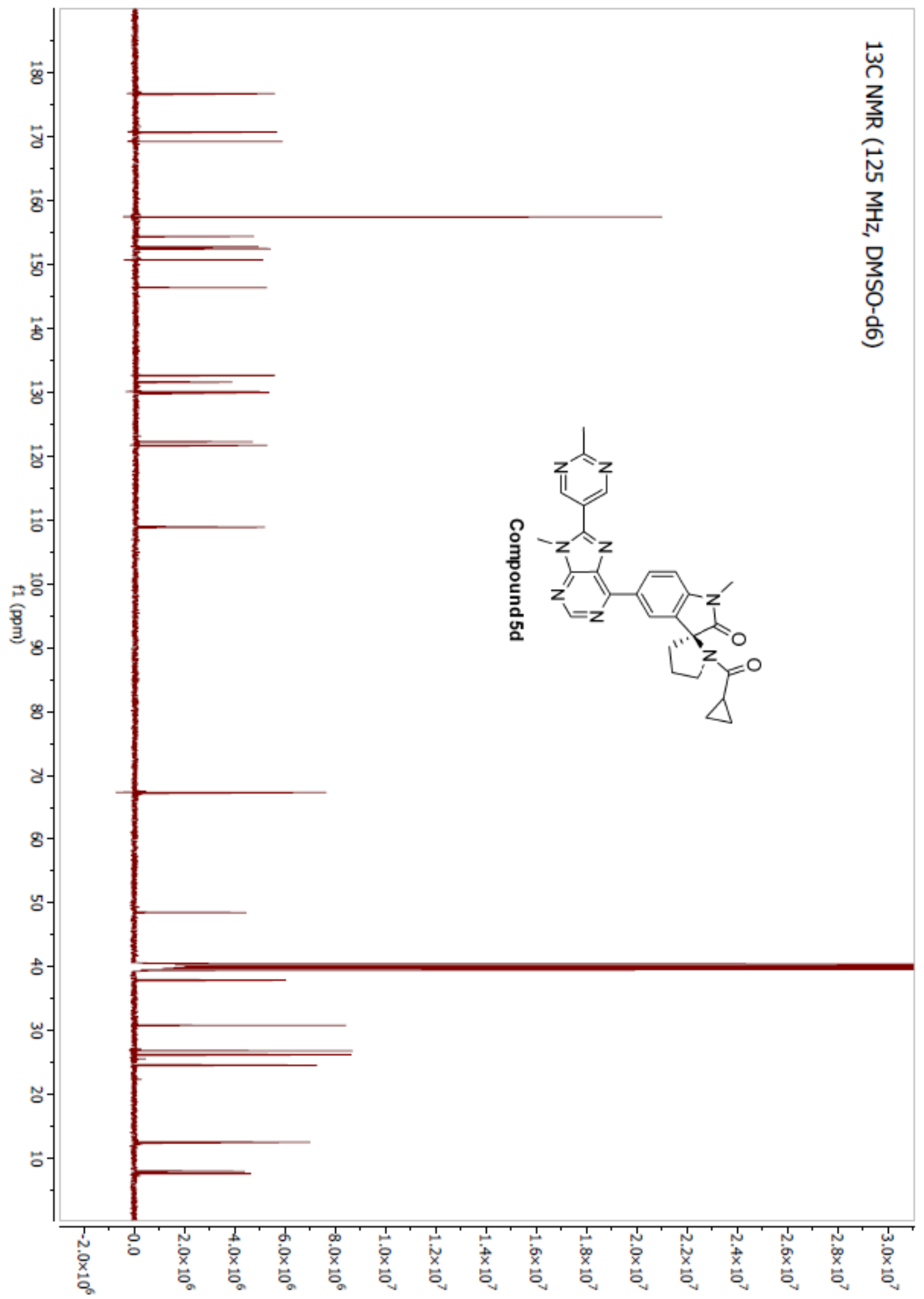

